ALO-3633-4

UC 33

AEC RESFARCH AND DEVELOPMENT REPE:SPECIAL

\title{
CFSTI PEICES
}

на. $2.00: \operatorname{mox} 65$

\section{AT $(30-1)-3633$ \\ DEVELOP 1800F-40OF FIBROUS-TYPE INSULATION FOR RADIOISOTOPE POWER SYSTEMS}

Tourth Quarterly Progress Report

ronort in. 11.0-3633-4

April 3, 1967

Pewnrt Period: January 2, 1967 to March 31, 1967

J. 0. Collins

\section{LEGÄL NOTICE}

This report was prepared as an account of Government sponsored work. Nelther the Untted States, nor the Commssion, nor any person acting on behalf of the Commission

A Makes any warranty or representation, expressed or implied, with respect to the accuracy, completeness, or usefulness of the information contained in this report, or that the use of any information, apparatus, method, or process disclosed in this report may not infringe privately owned rights, or

B Assumes any liabilities with respect to the use of, or for damages resulting from the use of any information, apparatus, method, or process dlsclosed in thls report.

As used in the above, "person dcting on behalf of the Commisaion" includes any employee or contractor of the Commission, or employee of such contractor, to the extent that such employee or contractor of the Commission, or employee of auch contractor prepares, disseminates, or provides access to, any information pursuant to his employment or contract with the Commission, or his employment with such contractor 


\section{DISCLAIMER}

This report was prepared as an account of work sponsored by an agency of the United States Government. Neither the United States Government nor any agency Thereof, nor any of their employees, makes any warranty, express or implied, or assumes any legal liability or responsibility for the accuracy, completeness, or usefulness of any information, apparatus, product, or process disclosed, or represents that its use would not infringe privately owned rights. Reference herein to any specific commercial product, process, or service by trade name, trademark, manufacturer, or otherwise does not necessarily constitute or imply its endorsement, recommendation, or favoring by the United States Government or any agency thereof. The views and opinions of authors expressed herein do not necessarily state or reflect those of the United States Government or any agency thereof. 


\section{DISCLAIMER}

Portions of this document may be illegible in electronic image products. Images are produced from the best available original document. 


\section{LEGAL NOTICE}

This report was prepared as an account of Government sponsored work. Neither the United States, nor the Commission, nor any person acting on behalt of the Commission:

A. Makes any warranty or representation, expressed or implled, with respect to the accuracy, completeness, or usefulness of the information contained in this report, or that the use of any intormation, apparatus, method or process disclosed in this report may not infringe privately owned rights; or

B. Assumes any liablilities with respect to the use of, or for damages resulting from the use of any information, apparatus, method, or process disclosed in this report.

As used in the above "person acting on behalt of the commission" includes any employee or Contractor of the Commission, or employee of such contractor, to the extent that such employee or contractor of the Cormission, or employee of such contractor prepares, disseminates, or provides access to, any information pursuant to his employment or contract with the commission, or his employment or contract with the Commission, or his employment with such Contractor.

Printed in U.S.A. Price Avallable from The Office of Technical Services, Department of Commerce, Washington 25, 0.C. 
ALO-3633-4

UC 33

AEC RESEARCH AND DEVELOPMENT REPORT SPECIAL.

i i i

\section{DISTRIBUTION}

L. W. Otoski, Area Manager

Sandla Area Office

U. S. Atomic Energy Commission

Al buquerque Operations of $f$ ice

Albuquerque, New Mexico 87115

(2 cys)

\section{A. J. Clark, Manager \\ I sotope Power Department \\ Department 9330 \\ Sandia Corporation \\ Post Office Box 5800}

Albuquerque, New Mexico 87115 (l cy)

R. T. Carpenter, Chief

Isotopic Power Branch

Division of Space Nuclear Systems

U. S. Atomic Energy Commission

Washington, D.C. 20545

\section{S. J. Selken}

Division of Reactor Development and Technology

U. 7. Atomic Energy Conmission

Washinglon, D.C. 20545

J. E. Konklin, Acting Chief

Technology Development Branch

Special Projects Division

U. S. Atomic Energy Commission

New York Operations Office

376 Hudson Street

New York, New York 10014

(l cy)

L. Sisler

I sotope Power Laboratory

Minnesota Mining \& Manutacturing Co.

Space Center, 2501 Walnut Street

Roseville, Minnesota 55119
(2 cys) (l cy)
J. F. O'Brien

Martin Marietta Corporation

Nuclear Products

Baltimore, Maryland 21203 (l cy)

K. Dufrane

Martin Marietta Corporation

Nuclear Products

Baltimore, Maryland 21203 (l cy)

E. Ray

General Electrlc Company

Missile \& Space Development

Valley Forge Space Technology Center

Post Office Box 8555

Philadelphia, Pennsylvania 19101 (2 zis

Will lam Botts

Atomics International

Division of North American Aviatiun

fust of ilce Box 309

(1 cy) Canoga Park, California 91304 (2 cys)

P. Underhill, Project Manager

Large Mill iwatt Program

Aerojet-General Nucleonics

Post Office Box 77

San Ramon, California' (l cy)

F. Hittman, General Manager

Hittman Associates, Inc.

4715 E. Wabash Avenue

Baltimore, Maryland 21215 (1 cy) 
ALO-3633-4

UC 33

AEC RESEAROH AND DEVELOPMENT REPORT SPECIAL

iv

J. Kenney, Program Manager Compact Thermoelectric Converter Westinghouse Electric Corporation Post Office Box 10864

Pittsburgh, Pennsylvania 15213

W. Kortier

Battelle Memorial Institute

505 King Avenue

Columbus, Ohio 43201

J. Epstein

Goddard Space Flight Center

Greenbelt, Maryland

Captain Morrow

Wright-Patterson Air Force Base

Dayton, Ohio 45433

J. O. Collins

Johns-Manville Research and

Engineering Center

Marivilla, Neaw Jarsoy OBE 35
( 1 cy)

$(1 c y)$

( I cy)

( 1 cy)

(2 cys)

(2 cys)
H. S. Potter, Chief

New York Patents Group

U. S. Atomic Energy Commission

Brookhaven Area Office

Upton, New York 11973

(1 cy)

J. Dunlay

Thermo Electron Engineering Corp. Post Office Box 482

Waltham, Massachusetts $02154 \quad$ (2 cys)

Harold Garber

NUMEC

609 North Warren Avenue

Apollo, Pennsylvania 15613

( $1 \mathrm{cy})$

U. S. Atomic Energy Commission

New York Operations Office

376 Hudson Street

New York, New York 10014

Attn: Reports Library

$\left(\mathrm{cy}^{\prime}\right.$

U. S. Atomic Energy Commission

Division of Technical Information Extension

Post Otflice BOX 62

Oak Ridge, Tennessee 37831 and one reproducible copy)

W. Dewitt

Union Carbide Corporation

Linde Division

Post Office Box 44

Tonawanda, New York 14152

G. Rose

Radio Corporation of America

415 South Fifth Street

Building 10-2

Harrison, New Jersey 
ALLO-3633-4

UC 33

AEC RESEARCH AND DEVELOPMENT REPORSPECIAL

v

\section{ABSTRACT}

by

J. 0 . Collins

This is the Fourth Quarterly Report for ABC Contract AT(30-1)-3633 covering the period January 1967 through March 1967.

Some of the long term ( $2000 \mathrm{hr}$ ) evaluations of Formulations 1999 and 2002 have been completed; others will be completed during the Fifth Quarter.

Formulation 2020 has been designated for service with the SiGe RTG's at 1800F. Long term testing pertinent to this material has been initiated. 
TABLE OF CONTENTS

Page

Legal Notice..................... . II

olstribution.......................... ili

Abstract ...................... . v

1. Introduction ........................ 1

11. Final Screening ..................... 2

111. Detailed Evaluation .................... 5

IV. Material and Process Development . . . . . . . . . 40

V. Summary of Fourth Quarter Results and Conclusions . . . . 46

VI. Fifth Quarter Effort ................ 48

VII. Keterences..................... . 49

VIII. Appendix A. . . . . . . . . . . . . . 50

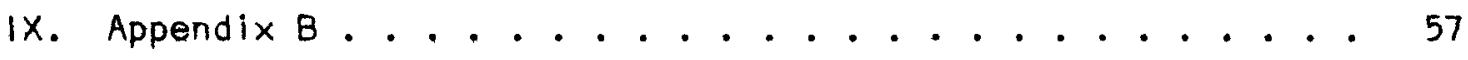




\section{LIST OF FIGURES}

Page

Figure 1. Formulation 2002 Pumpdown and Outgas Cycles at Room Temperature ............... 8

Figure 2. Formulation 2002 Pumpdown and Outgas Cycles at 400F ...................... 9

Figure 3. Formulation 2002 Pumpdown and Outgas Cycles at

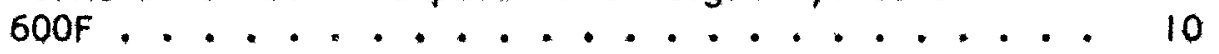

Figure 4. Effect of Static Preload on Frequency of First Response of Formulation 2002 . . . . . . . . 16

Figure 5. Change in Dynamic Modulus of Elasticity with Static Preload for Formulation 2002 . . . . . 17

Figure 6. Variation of Damping Coefficient with Static Preload of Formulation 2002 . . . . . . . .

Figure 7. Moisture Adsorption of Formulation 2002 in

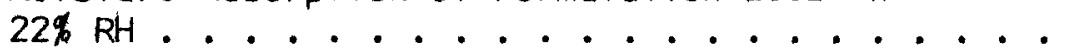

Figure 3. Moisturo Adsorplion of Formulation 2002 in

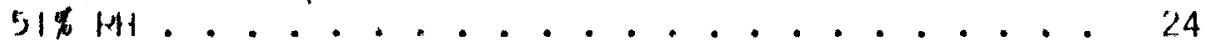

Figure 9. Molsture Adsorption of Formulation 2002 in 918 RH............... 25

Figure 10. Moisture Desorption of Formulation 2002 after

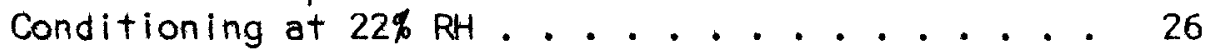

Figure 11. Molsture Desorption of Formulation 2002 after Conditioning at 51\% RH.......... . 27

Figure 12. Moisture Desorption of Formulation 2002 after Conditioning at 91\% RH ............ 


\section{LIST DF FIGURES (Continued)}

Page

Figure 13. Load Relaxation of Formulation 2002 . . . . . . 30

Figure 14. Thermal Conductivity in Alr of Formulations

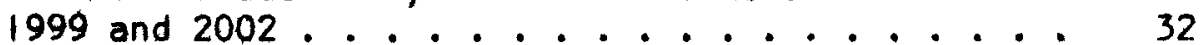

Figure 15. Thermal conductivity in Alr of Irish REFRASIL at 10.3 pcf and DYNAQUARTZ at 10.0 pcf ..... 


\section{LIST OF TABLES}

Page

Table 1. Effect of 200 psl and $1700 \mathrm{~F}$ (Avg) Hot Face upon Carborundum's T30LR Laminate after

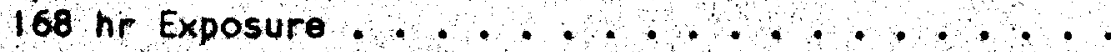

Table 2. Analysis of Argon Used In Outgassing Evaluation . . 7

Table 3. Water Content and Resldual Gas Anelysis ot $600 \mathrm{~F}, \ldots \quad 7$

Table 4. Water Content and Residual Gas Analysis at 1000F , 12

Table 5. Water Content and Residual Gas Analysis at $1400 \mathrm{~F} \ldots \quad 12$

Table 6. Second Water Content and Residual Gas Analysis at

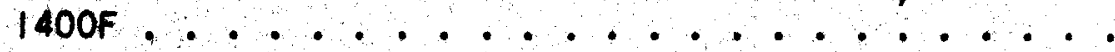

Table 7. Average Dynamlc Properties .............

Table 8. Thermal Stability of Formulation 2002 . . . . . .

Table 9. Dimensional Change of Formulation 2002 after Hot

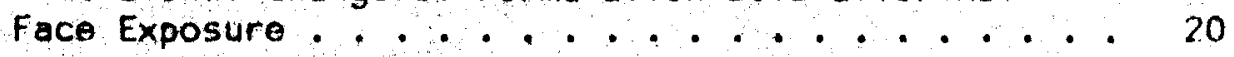

Table 10. Equilibrium Moisture Content of Formulation 2002 at Varlous Humldity Levels... . . . . . . 29

Table 11 . Effect of Load on Thlckness Shrinkage of

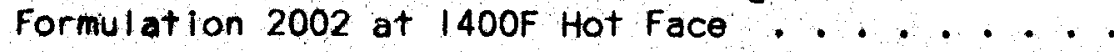

Table 12. Sige Compatibllity in Alr at l600F ........

Table 13. Sige Compatibllity in Vacuum at l600F . . . . . 
Table 14. Copper Content by Spectrographic Analysis of the Fibrous Insulations - after $2000 \mathrm{hr}$ at $1600 \mathrm{~F}$

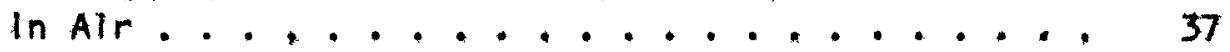

Table 15. Fourth Quarter Experlmental MIN-K Formulations . . 41

Table 16. Thermal Stability of Experimental Formulations

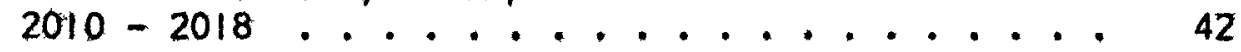

Table 17. Isothermal Shrinkage at $1800 \mathrm{~F}$ of Formulations $2020,2023,2024$, and 2025 ............... 44

Table 18. Modulus of Rupture of Formulations 2020, 2023,

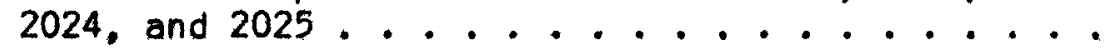




\section{INTRODUCTION}

Long term testing of Formulations 1999 and 2002 for lead tellumlde RTG applications vas completed for several of the physical properties. These Included cheml cal compatiblilty with PbTe elements (final results otill under analysis), load relaxation, and thermal stability. Outgassing and thermel conductivity tests were inftiated during this quanter, but have not been completed. Other physical properties such as dynumic response, molsture adsorption/desorption, and shear have been completed.

Chemleal compatibility in alr between sige elements and the fibrous candidates hes completed the $2000 \mathrm{hr}$ evaluation level. The same test in vacuum is approaching the $1500 \mathrm{hr}$ level. Tests have also been inftiated to evaluate the effect of prolonged contact between Irish REFRASIL and SiGe bars as detemined by seebeck voltage and resistivity measurements.

The effort to improve the temperature resistance of the MIN- $K$ formulations has been concluded with the cholce of Formulation 2020 . Long term tests on this material were initiated. 


\section{FINAL SCREENING}

\section{A. CARBORUINDUM T3OLR}

Tour specimens of carborumdun's T30LR laninate $(4 \times 4 \times 0.84$-in.) were subjected to a constant $10 a d$ of 200 p61 for $168 \mathrm{hr}$ ( 1 week), at an elevated hot face to determine its load bearing characteristics. The product was sanded from its homlaal 1-in. thickness to insure a flat specimen with a unl form bearing surface. The product ranged In density from 53.3 pef to 54.9 pce for the four specimens, and averaged $54.0 \mathrm{pcf}$.

It was originally intended that these tests be conducted at 1800 p hot face. Hovever, due to the high thermal conductance of the material (relative to standard insulations), and the power limitations of the heater unit, these tests had to be conducted at temperatures averaging approximately $1700 \mathrm{r}$. The hot face Indicating thermocouple of one specimen became erratic during the second and third days of test, indicating temperatures as high as $1800 \mathrm{~F}$ and 1900F. It subsequently became useless. The control to the heaters was not changed during this perlod, nor for the remainder of the test, however, since the hot face couple was considered faulty. This decision was supported upon completion of the test when the measured shrinkage of the specimen was typical of the remaining three values.

Table 1 summarizes the data obtained for this product. The thickness shrinkage averaged 3.4 per cent. All changes in length or width almensions were within the limits of measuring error.

This product did not prove itself to be as satisfactory for load bearing applications as the GLASROCK 25 product. No further work was done.

\section{B. GLASROCK 25}

Four specimens of GLASROCK 25 were tested for modulus of rupture (bend strength) at room temperature (test procedure presented in Third Quarterly Report). The specimens were $8 \times 4-1 / 2 \times 1-i n$. nominal size and were tested across a 7-in. span. The range of values was from $150 \mathrm{psi}$ to $195 \mathrm{psi}$ with an average of 172 pst. Therefore, although the material has been proven to be satisfactory. in compression, it should not be subjected to excessive bending or tensile loads. 
TABLE 1 .

EFFECT OF 200 PSI AND $1700 F$ (AVG) HOT FACE UPON CAREORINDUM'S T3OLR LAMINATE AFTER 168 HR EXPOSURE

\begin{tabular}{|c|c|c|c|c|}
\hline Speclimen & $\begin{array}{l}\text { Density } \\
\text { pef }\end{array}$ & $\begin{array}{c}\text { Hot Face } \\
\text { of } \\
\end{array}$ & $\begin{array}{c}\text { Cold Face } \\
\text { OF } \\
\end{array}$ & Thick. Shrinkage \\
\hline A & 54.9 & $\begin{array}{l}1726 \mathrm{ovg} \\
1745 \mathrm{max} \\
1700 \mathrm{~min}\end{array}$ & $\begin{array}{l}398 \text { avg } \\
401 \text { max } \\
395 \text { min }\end{array}$ & 3.4 \\
\hline B & 53.3 & $\begin{array}{l}1695 \text { avg } \\
1699 \text { max } \\
1683 \mathrm{~min}\end{array}$ & $\begin{array}{l}376 \text { avg } \\
382 \text { max } \\
369 \text { min }\end{array}$ & 2.9 \\
\hline C & 53.6 & $\begin{array}{l}1710 \mathrm{avg}^{*} \\
1710 \mathrm{max} \\
1708 \mathrm{~min}\end{array}$ & $\begin{array}{l}379 \text { avg } \\
385 \text { max } \\
375 \text { min }\end{array}$ & 3.5 \\
\hline$D$ & 54.2 & $\begin{array}{l}1667 \text { avg } \\
1685 \text { max } \\
1635 \mathrm{~min}\end{array}$ & $\begin{array}{l}447 \text { avg } \\
460 \mathrm{max} \\
435 \mathrm{~min}\end{array}$ & 3.7 \\
\hline
\end{tabular}

*Average of four readings only due to thermocouple malfunction. 
GLAsRocx 25 was also subjected to shear tests (see deseription of tegt procedure under III - Detalled Ivaluation) and found to average $210 \mathrm{psi}$ with range of $186 \mathrm{psi}$ to $225 \mathrm{psi}$ for twelve specimens. This test was conducted parallel to the thickness surfaces.

A $12 \times 12 \times 1-$ in. specimen tested for thermal conductivity in the JohnsManvilie Rapid Heat Meter ApparatuB at 73 F and 800 nean temperatures. The values vere 0.8 and $1.4 \mathrm{Btu}$ in. $/ \mathrm{hr}$ sq ft $0 \mathrm{~F}$, respectively, at the two temperatures. The manufacturer's 11terature indicated thermal conductivity of $1.0 \mathrm{Btu}$ in. $/ \mathrm{hr}$ sq $\mathrm{ft}$ o at 1000 mean temperature. The previous $1 \mathrm{y}$ vertfied error connected with the Heat Meter equipment is \pm 8 per cent when testing this type of high conductivity material. Consequently, it wust be ssaumed that the published data vere incorrect. Nonetheless, the conductivity should be considered good when compared with similar type materlals which have significantly less compression resistance than the GLASROCK 25. 



\section{Outractere of Formulation 2002}

The prelininary stages of the outgassing test have been completed, and the opecimens are currently on long term (2000 hr) exposure. The purpose of this early pheae of the test was to ettexpt to gain sowe insight into the affect of varfous atmospheric moisture contents on the ease of removal of this moleture at low temperatures, and with numerous argon backflil aycles. The test procedure is given in Appendix $A$.

To sumarlize, four ceramic tubes were preconditioned to $1600 \mathrm{~F}$ under vacuum, cooled to room temperature, and backfilled with air bled through magnesium perchlorate drying columans. One tube was opened, a 200-gm specimen (no opeciflc prior condtioning) inserted, and the tube recloged. All tubes vere then heated to $1050 \mathrm{~F}$ in the dry air atmosphere for $30 \mathrm{~min}$, evacuated for an additional $30 \mathrm{~min}$, and subsequently cooled to room temperature under active vecuu. This conditioning of the one specimen represented a simulation of the heat and vacum to which the standard MII-K 1301 specimens are subjected prior to generator assembly.

All tubes were backfilled again with ary air, and 200-gm specimens previously conditioned to $33 \% \mathrm{RH}$ at $75 \mathrm{~F}$ and $90 \% \mathrm{RH}$ at $90 \mathrm{~F}$ were inserted into two of the three enty tubes. The fourth tube remained expty throughout the test. Each tube was then individually pumped down at room temperature for 15 min, and then allowed to outgas (no active puming) for an additional 15 min. This procedure ves repeated for a totel of three pumpdown and outgassing cycles.

Following the room temparnture pumpdown and outgassing cycles, the system was helium leak checked. This was done by basging each fitting and filling the bas with hellum while evacuating the system through a hellum detecting system. After several adustments, all joints (including the vIrON gasket joint between the ceremic tubes and the stainless steel vacuum system) showed a leak rate of less than $5 \times 10^{-10} \mathrm{cc} / \mathrm{sec}$. The porosity of the tubes themselves could not be meesured due to the configuration of the test equipment. Consequently, these constitute the only source of leak.

The three pumpdown and outgassing cycles were then repeated on each tube individualiy at $400+20 \mathrm{~F}$ and at $600+20 \mathrm{~F}$. Following the final cycle at $600 \mathrm{~F}$, the tubes were backfilled with argon (see Table 2 for analys1s) to approximately $1030 \mathrm{Hg}(20 \mathrm{psia})$ and held at these conditions for a ninimum of $96 \mathrm{hr}$. 
TABLE 2.

ANALYSIS OF ABOON USED IN OUTEASSIMS EVALUATION

$\begin{array}{rr}\text { constltusnt } & \text { content o } \\ N_{2} & <2.0 \\ \mathrm{O}_{2} & <1.0 \\ \mathrm{CO}_{2} & \text { not detected, }<0.5 \\ \mathrm{CO} & \text { not detected, }<0.5 \\ \mathrm{H}_{2} & \text { not detacted, }<1.0 \\ \mathrm{CH}_{4} & <0.4 \\ \mathrm{H}_{2} \mathrm{O} & <8.0\end{array}$

A plot of prousure veruiv time for each of the tubes and at each of the throe temperature levels is shown in Figures 1,2 , and 3 . It will be noted that the pupdown and outgassing rates followed the anticipated pattern besed upon the water contents of each specinen.

Water conteat and residun gas enalyses were mu on each tube. The results of these shalyes are shown in Table 3 . The rater analysis ras run using a Conolldated Mlectrodynamics Corporation molsture monitor which directly masures vater content by voluee as it is bled from the tubes. The residual cases vare detexulned on a mass spectroweter capable of detectins mass 2 to meses 100.

TNILE 3:

WATER CONTENT AND RESIDUAL GAS ANALYSIS AT 600F

\begin{tabular}{|c|c|c|}
\hline $38 \mathrm{FH}$ & $90 \$ \mathrm{PH}$ & $\begin{array}{c}\text { Preconditioned } \\
\text { at } 1050 \mathrm{~F}\end{array}$ \\
\hline
\end{tabular}

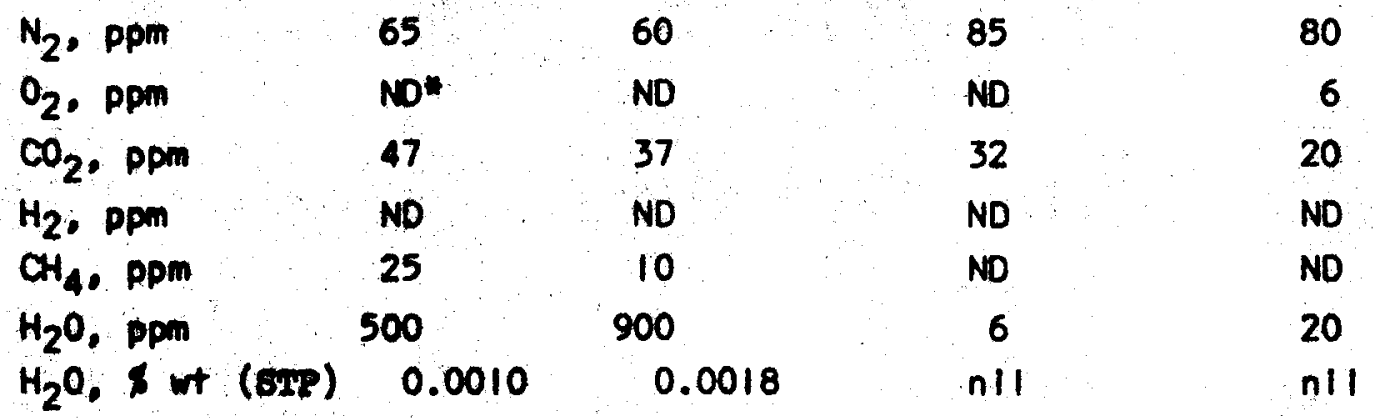

Wot defoctod, less than 4 ppm. 
FIGURE 1.

FORMULATION 2002 PUMPDOWN AND OUTGAS CYCLES

AT ROOM TEMPERATURE

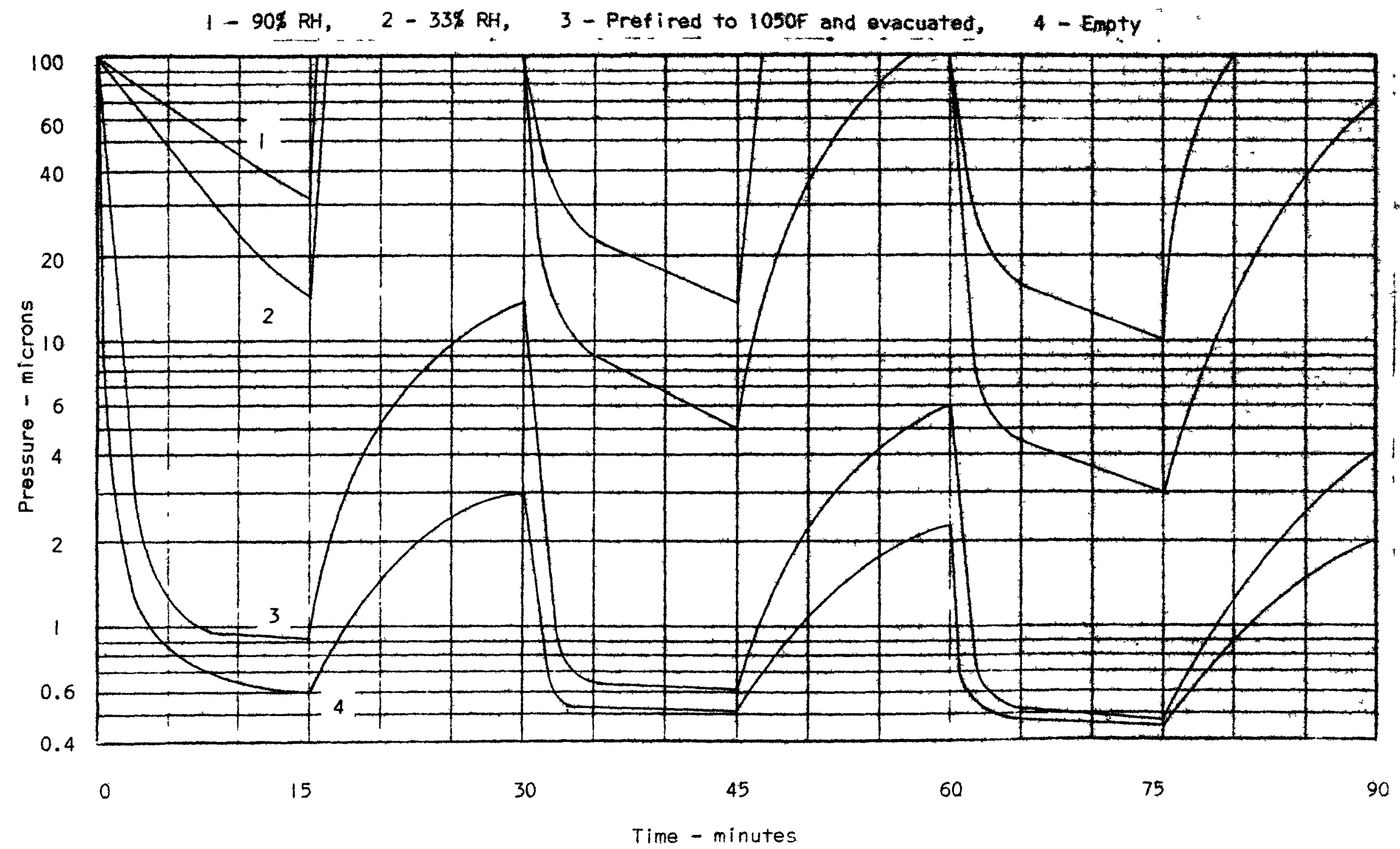


FIOURE 2.

FORMULATION 2002 PLAPOONN AMD OUTGAS CTCLES AT AOOF

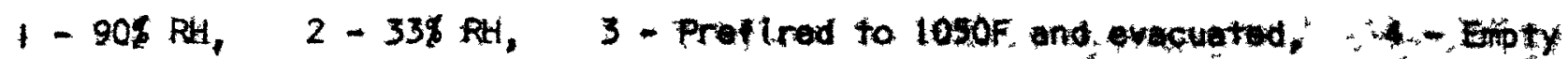

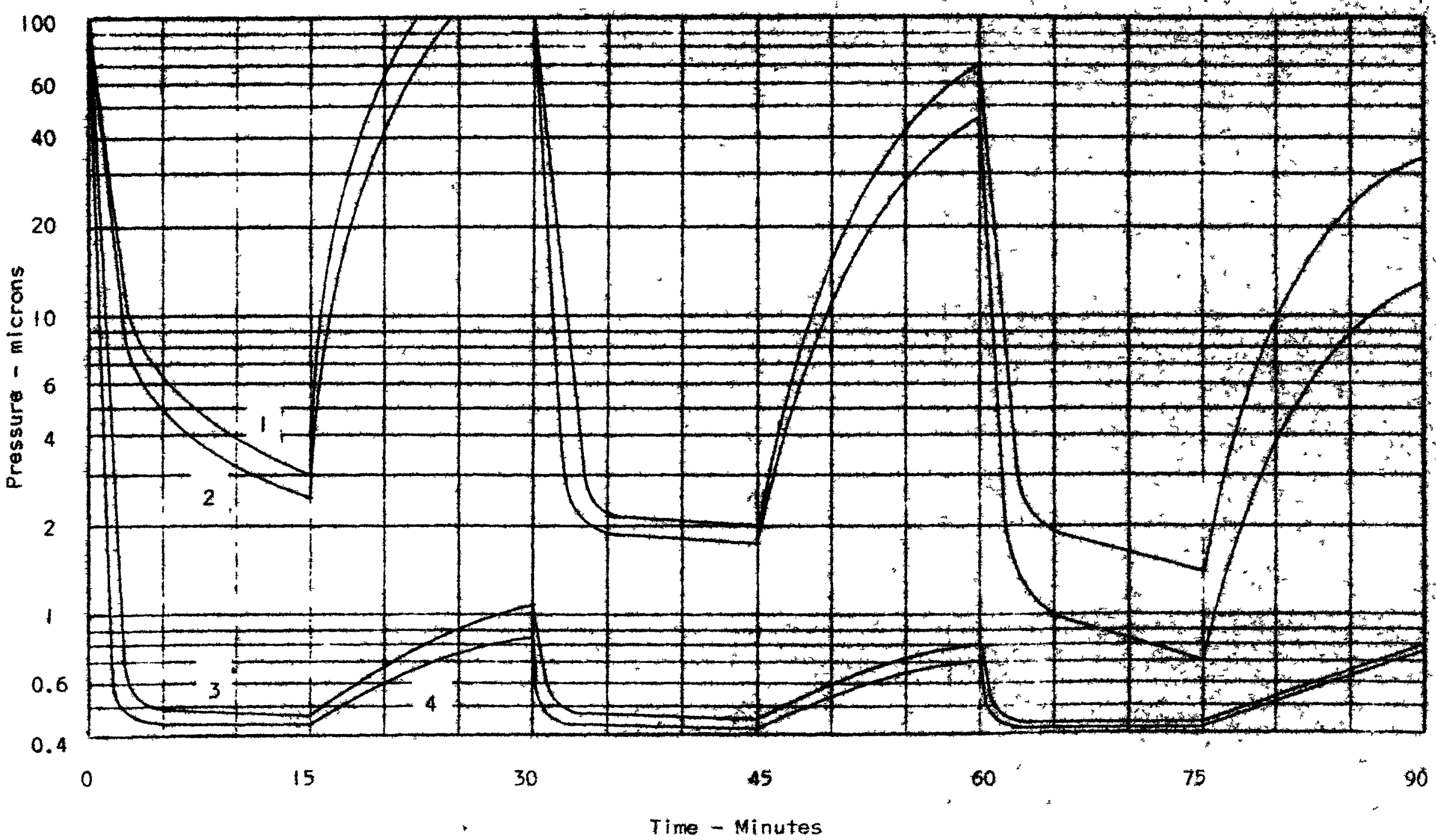


FIOURE 3 .

FORMULATION 2002 PUMPOMU NID OUTGAS CTCEES NT $600 \mathrm{~F}$

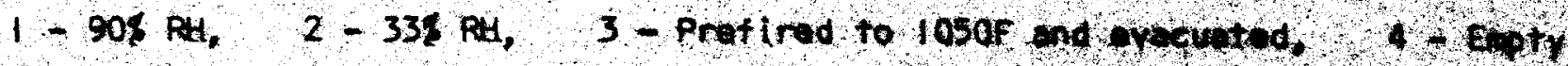

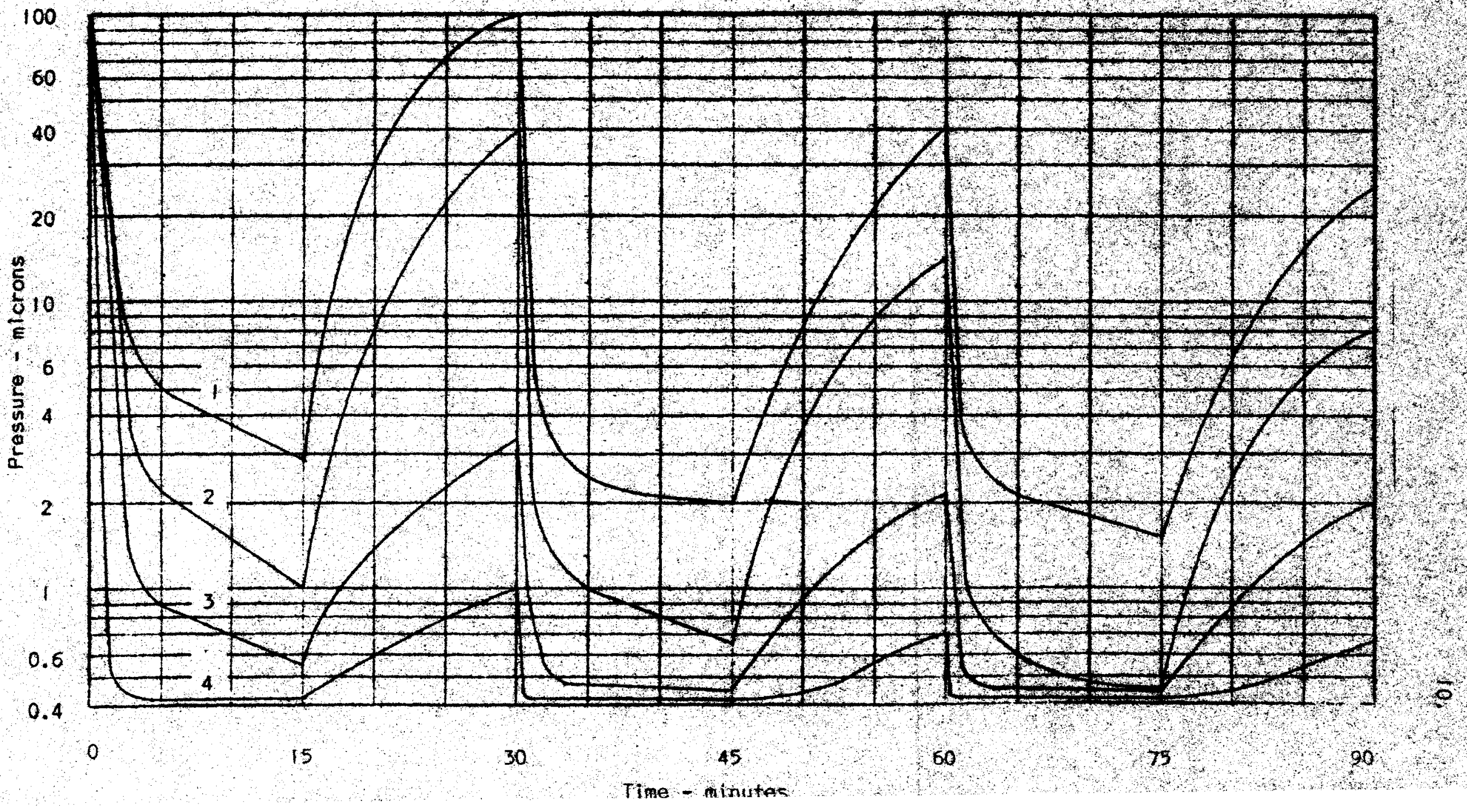


We rotere eontent ves then converted arom pen by voluen to per cent by wetht of the telt peclien at Gip using the following equet for:

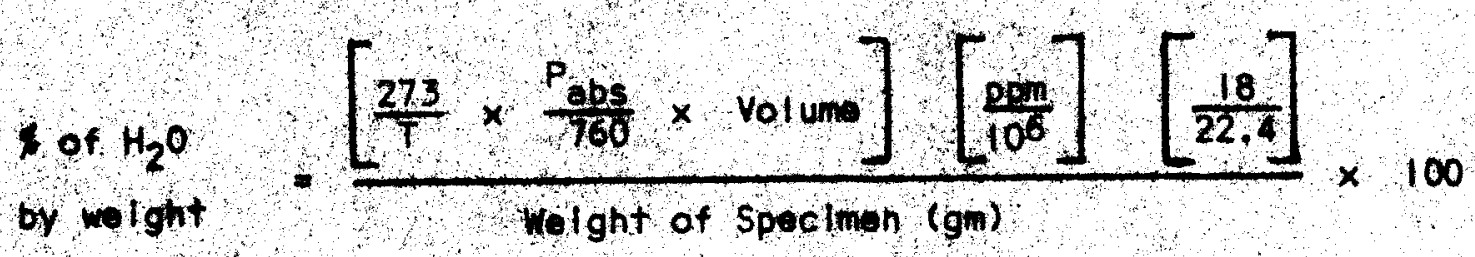

where:

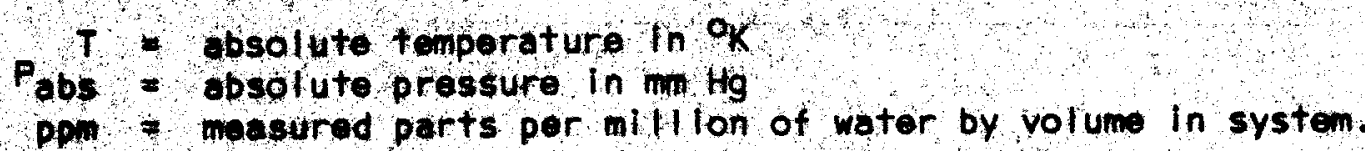

Thu, the tube contalning the 338 Bt epecimen contalned 0.0010 per cent weter, and the tube conteining the $90 \%$ fil specimen contained 0.0018 per cent

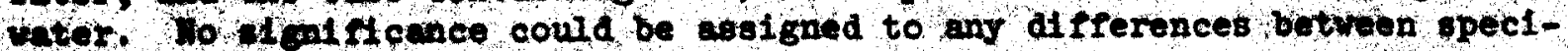
wins in the restadias analyses.

The thin pumadon and outgaselng cycles vere repeated at $600 \mathrm{~F}$ for the two tubes thowins the higher water contents. However, after each cycle, the twos rese proweral zad with argon for a minimum of 5 win to Investigate the

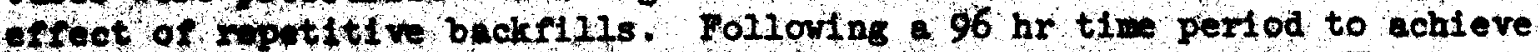

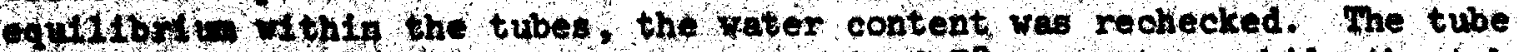
conthlins the 33 , all specinen now contalned 78 ppr water, whlle the tube contaluting the $90 \mathrm{x}$ al opecinen ot 111 contalned 620 ppm vater. At this point In the tost. It oppeared that the flushings had a greater effect on the apectoon contalning the lesser anount of water initially.

The tubes vere then heated to $1000+20 \mathrm{r}$ (argon press ure held at epproximately. $1030 \mathrm{ang}$ ) and allowed to come to equilibrium for a minimum of $96 \mathrm{hr}$. The water content and realdual gas anelyses determined at $1000 \mathrm{~F}$ are given in Table 4.

Based upon thermogravimetric analyses conducted on the raw materials which comprite Formulation 2002 , and typical formulations (1), It was epperent that the vater which was detected at $1000 \mathrm{~F}$ constituted chemically comblined vater rather than adsorbed molsture. 
TNBLE 4.

WATER CONTENT AND RESIDUAL GAS ANALYSIS AT IOOOF

\begin{tabular}{|c|c|c|c|c|}
\hline & $334 \mathrm{RH}$ & $905 \mathrm{BH}$ & $\begin{array}{l}\text { Preconditloned } \\
\text { at } 1050 \mathrm{~F} \\
\end{array}$ & Engty \\
\hline $\mathrm{N}_{2}, \mathrm{PRN}$ & 120 & 160 & 330 & 250 \\
\hline $\mathrm{O}_{2}, \mathrm{ppm}$ & ND & ND & No & ND \\
\hline $\mathrm{CO}_{2}, \mathrm{ppm}$ & 610 & 750 & 590 & 320 \\
\hline Co, ppm & 60 & 22 & NQ & ND \\
\hline $\mathrm{H}_{2}$, ppm & ND & 330 & NO & ND \\
\hline $\mathrm{CH}_{4} \cdot \mathrm{Ppm}$ & ND & 6 & NO & ND \\
\hline $\mathrm{C}_{2} \mathrm{H}_{4} \cdot \mathrm{ppm}$ & ND & 15 & ND & ND \\
\hline $\mathrm{H}_{2} \mathrm{O}$. ppm & $>1000$ & $>2,000$ & 150 & 225 \\
\hline $\mathrm{H}_{2} \mathrm{O}, \& w+(S T P)$ & $>0.0015$ & $>0.0030$ & 0.00023 & \\
\hline
\end{tabular}

Each tube wen agaln pumped down, allowed to outgas, and backfilled with arcon for a total of three cycles at $1050 \mathrm{~F}$. The times vere changed, however, to $30 \mathrm{~min}$ for the flrst pumpdown, and 5 min for each subsequent outgas and pupdown to colncide with current generator procedures at $1050 \mathrm{~F}$ hot face. The tubes vere than heated to $1400 \pm 20 \mathrm{~F}$ at $1030 \mathrm{H}$ argon and held for $96 \mathrm{hr}$. The vater content and residual gas analyses at $1400 \mathrm{~F}$ are givan in Table 5 .

TABLE 5.

WATER CONTENT AND RESIDUAL GAS ANALYSIS AT I400F

\begin{tabular}{|c|c|c|c|c|}
\hline & $331 \mathrm{RH}$ & $90 \% \mathrm{RH}$ & $\begin{array}{l}\text { Preconditioned } \\
\text { at } 1050 \mathrm{~F} \\
\end{array}$ & Empty \\
\hline $\mathrm{N}_{2}, \mathrm{ppm}$ & 530 & 260 & 400 & 260 \\
\hline $\mathrm{O}_{2}, \mathrm{ppm}$ & ND & ND & 6 & ND \\
\hline $\mathrm{CO}_{2}, \mathrm{ppm}$ & 1100 & 1750 & 500 & ND \\
\hline CO, ppm & 480 & 550 & 820 & ND \\
\hline $\mathrm{H}_{2} \cdot \mathrm{ppm}$ & 3600 & 10,000 & 10,000 & 560 \\
\hline $\mathrm{CH}_{4} \cdot \mathrm{pPm}$ & 33 & 120 & 140 & ND \\
\hline $\mathrm{C}_{2} \mathrm{H}_{6}$, Ppm & 7 & 22 & 7 & ND \\
\hline $\mathrm{H}_{2} \mathrm{O}$, ppm & $>2000$ & $>2000$ & $>2000$ & $<1$ \\
\hline $\mathrm{H}_{2} \mathrm{O}, 8$ wt (STP) & $>0.002$ & $>0.002$ & $>0.002$ & $n \|$ \\
\hline
\end{tabular}





FIGURE 4.

EFFECT OF STATIC PRELOAD ON FREOUENCY OF FIRST RESPONSE OF FOMULATION 2002

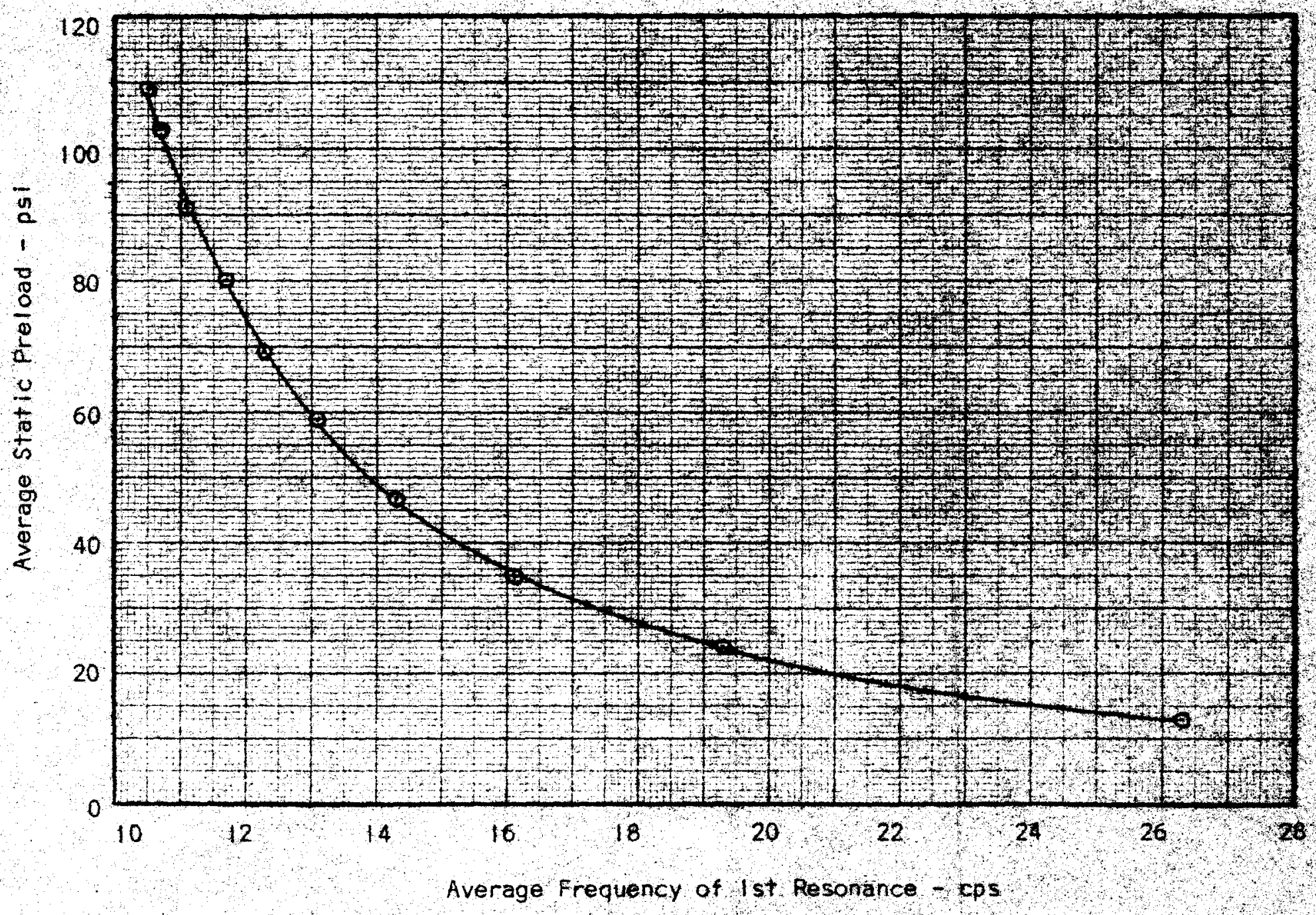


FIOURE 5

\section{OHANGE IN DYNAMIC MODULUS OF ELASTICITY \\ WITH STATIC PRELOAO FOR FORMULATION 2002}

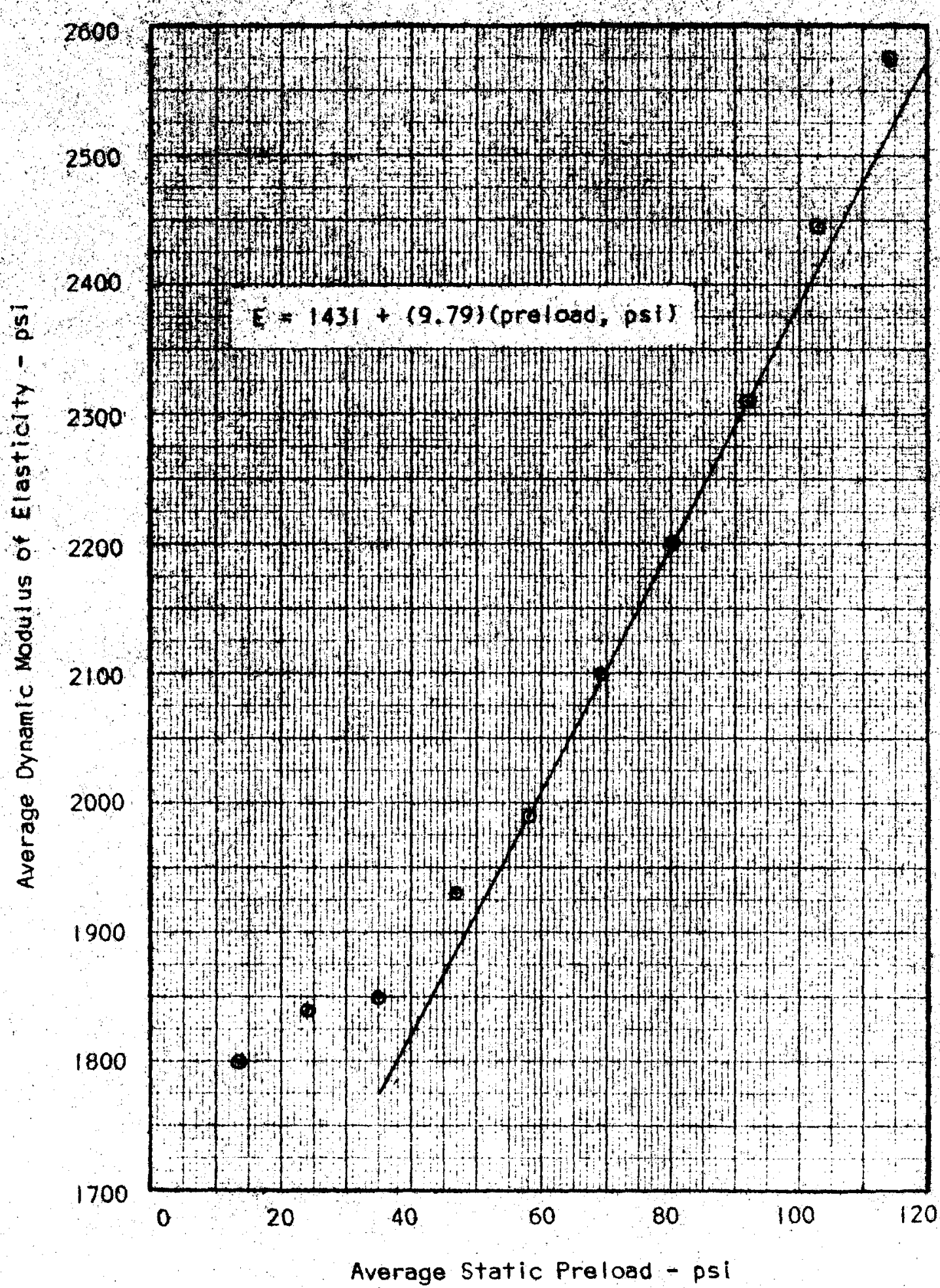


Also shown in Table 7 , is the average structural damping coefricient of 0.5 per cent. Ttgure 6 shous the slight, but conststent, change $1 \mathrm{n}$ damping coefrtclent with static preload. The slope $1 \mathrm{~s}$ small enough, horever, to be considered zero for all practical applications.

It is interesting to note that the damping goefficient is approxtmate ly half that messured for kin-K 1301, Martin Report (3), This was probably caused by the $14005,2 \mathrm{hr}$ firing cycle to which Formulation 2002 is subjected during manufacture. Had NAM-K 1301 been subjected to $1400 \mathrm{~F}$ prior to, or durfing the test. It is belleved that Its dauping coefficient would also have been lover due to sintering or alinliar phenomenon which occurs within these insulations at temperatures above $1000 \mathrm{~F}$.

Thermal Stability of Formulation 2002

The per cent shrinkage of Formulation 2002 after $2000 \mathrm{hr}$ of $1400 \mathrm{~F}$ isothermal oxposure vas presented previously $(2)$. Table 8 , shows the effect of exposing the ame specimens for an additional $100 \mathrm{hr}$ at $1500 \mathrm{~F}$ and $48 \mathrm{hr}$ at $1600 \mathrm{~F}$. Four of the orlginal twelve specimens were then exposed to $1600 \mathrm{~F}$ for a total of $1000 \mathrm{hr}$. These shrinkage date are also shown in Table 8.

TABLE 8.

THERMAL STABILITY OF FORMULATION $2002^{*}$

\begin{tabular}{|c|c|c|c|c|c|}
\hline & $\begin{array}{l}2000 \mathrm{hr} \\
\mathrm{e} \quad 1400 \mathrm{~F}\end{array}$ & $\begin{array}{l}100 \mathrm{hr} \\
\mathrm{e} 1500 \mathrm{~F} \\
\end{array}$ & $\begin{array}{l}48 \mathrm{hr} \\
-1600 \mathrm{~F}\end{array}$ & $\begin{array}{r}475 \mathrm{hr} \\
+\quad e 1600 \mathrm{~F} \\
\end{array}$ & $\begin{array}{r}1000 \mathrm{hr} \\
+\quad 1600 \mathrm{P} \\
\end{array}$ \\
\hline & 0.4 & 0.4 & 0.5 & 0.6 & 0.0 \\
\hline ago, $\%$ & 0.8 & 0.9 & 0.9 & 0.6 & 0.7 \\
\hline kage, & 0.8 & 0.8 & 0.9 & 1.2 & 1.4 \\
\hline
\end{tabular}

\#All values based on dimensions prior to any thermal exposure. Values are not cumulative.

The apparent "growth" of the specimens in the width direction during the $475 \mathrm{hr}$ exposure to $1600 F$ can probably be attributed to the accuracy of measurement, coupled with the effect of frequent thermal shock, upon the specimens as they were periodically heated and cooled. Nonetheless, it would appear that Formulation 2002 has a useful service temperature above the $1400 \mathrm{~F}$ limit for which it vas designed. 
FIG $-E$. 6

VARIATION OF DAMP, 0 COEFFICIENT WITH

STATIC PRELOAD OF FORMULATION 2002

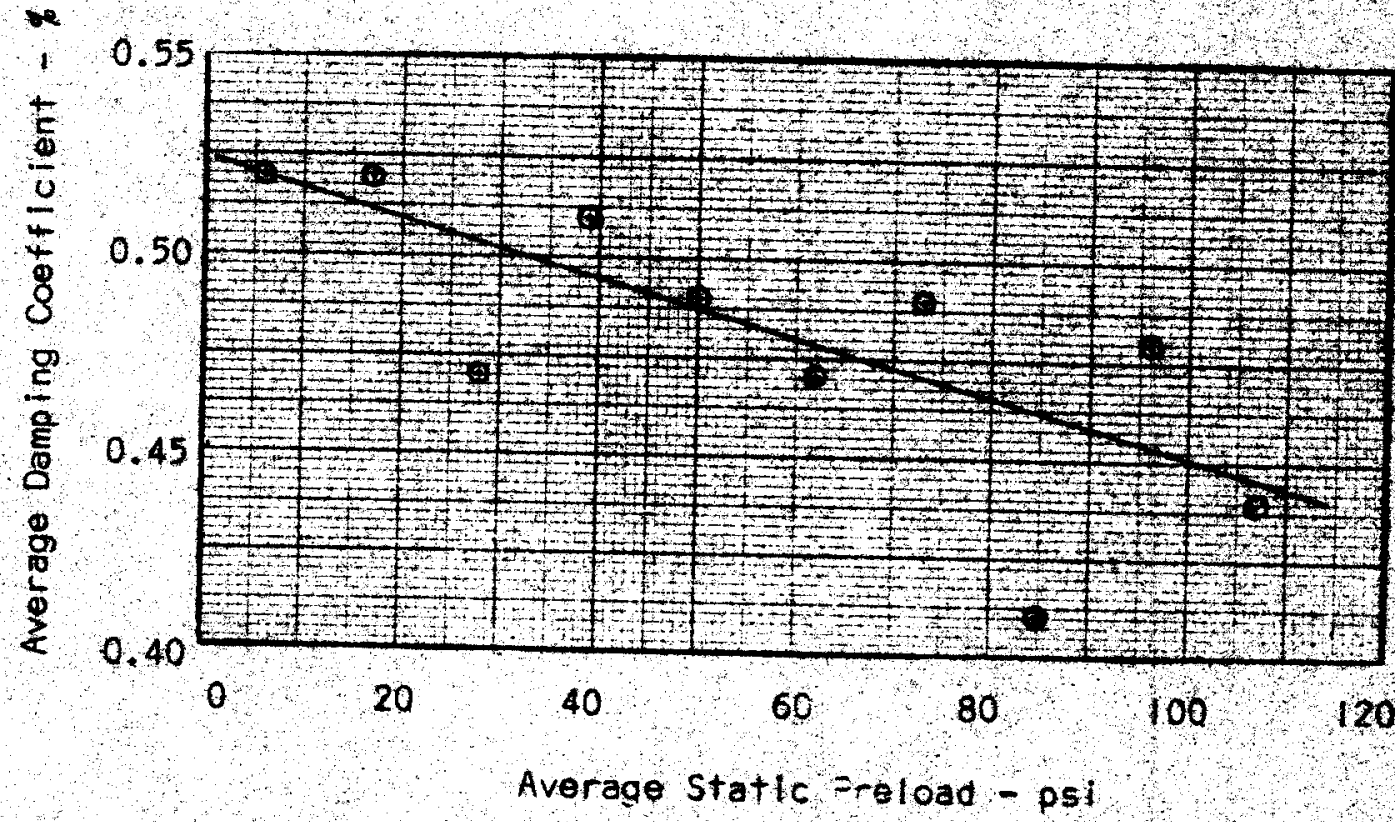


20.

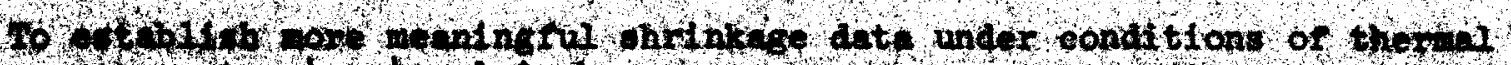

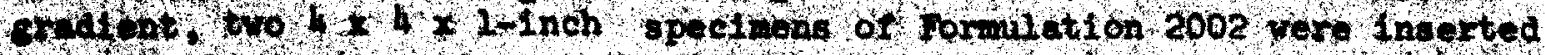

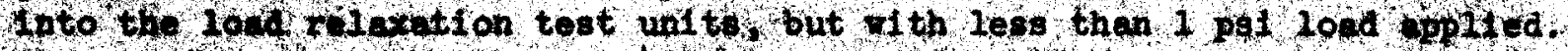

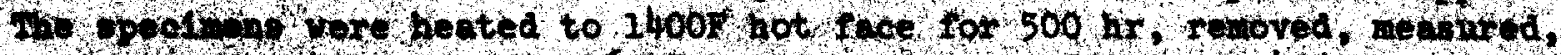

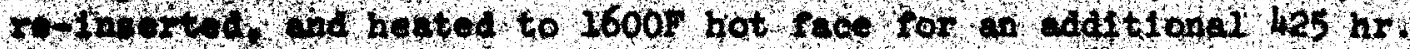

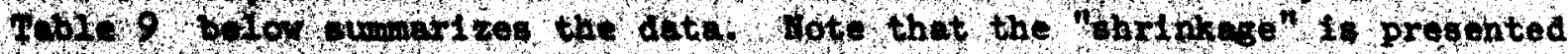

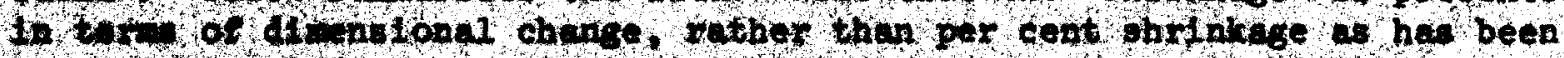

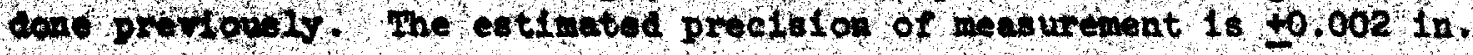

\section{TABLE 9.}

\section{DIMENSIONAL CHANOE OF FORMULATION 2002 AFTER HOT FACE EXPOSURE}

\begin{tabular}{|c|c|c|c|c|c|c|}
\hline $\begin{array}{l}\text { Spectinen } \\
\mathrm{No} \text {. }\end{array}$ & $\begin{array}{l}\text { Average } \\
\text { Hot Foce } \\
\text { of }\end{array}$ & $\begin{array}{l}\text { Average } \\
\text { Cold Face } \\
\text { of }\end{array}$ & $\begin{array}{c}\text { Exposure } \\
\text { Tlme } \\
\mathrm{hr} \\
\end{array}$ & $\frac{\text { Total }}{\text { Length }}$ & $\frac{\text { Dimensional }}{\text { Wtoth }}$ & $\frac{\text { Change, in. }}{\text { Thlickness }}$ \\
\hline $\begin{array}{l}1 \\
2\end{array}$ & $\begin{array}{l}1398 \\
1403\end{array}$ & $\begin{array}{l}283 \\
274\end{array}$ & $\begin{array}{l}500 \\
500\end{array}$ & $\begin{array}{c}n c^{*} \\
-0.002\end{array}$ & $\begin{array}{l}-0.001 \\
-0.002\end{array}$ & $\begin{array}{l}+0.002 \\
-0.004\end{array}$ \\
\hline 2 & $\begin{array}{l}1596 \\
1597\end{array}$ & $\begin{array}{l}671^{* *} \\
666^{* *}\end{array}$ & $\begin{array}{l}425 \\
425\end{array}$ & $\begin{array}{l}-0.004 \\
-0.008\end{array}$ & $\begin{array}{l}-0.005 \\
-0.005\end{array}$ & $\begin{array}{l}-0.002 \\
-0.005\end{array}$ \\
\hline
\end{tabular}

\footnotetext{
* No chango

* 1/2-In. MICRO-QUARTz placed over cold tace of specimen to increase mean temperature.
}

It sun we deen that at 1400 hot face, no length and width shrinkage could be elect d within the limits of measuring accuracy. Similariy, the measured thi eknots onilnkese vas considerably below that for the isothermal exposure (0.001 in. ropreasnts approximately 0.1 per cent of the original thickness). At $1400 \mathrm{r}$ lot face, only one of the specimens shoved what might be canstrued as "slonifloant shrinkege," although even then, it was well below the unorfictal godi or 1 per cent.

The 1600 f hot face tests were conducted such that both the hot face and the cold face (and hence the mean temperature) exceeded normal operating limits. Deeplte these exesserated conditions, the shrinkage remained below 1 per cent. The regult of isothermal versus hot face stability testing (comparing Table 8 Nith Table 9) was nost evident in the thickness dimension as antlo1pated, with the hot face tests representing the more realistic stability values. All atmenstons represent changes from the original dimensions prtor to eny hot fece exposure. 


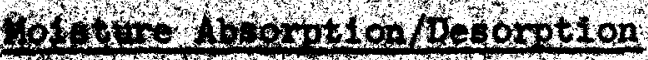

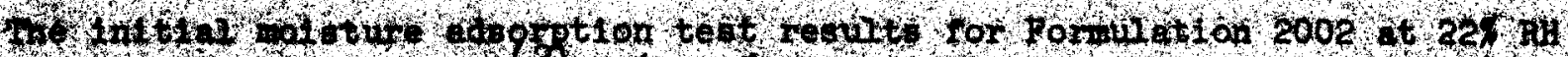

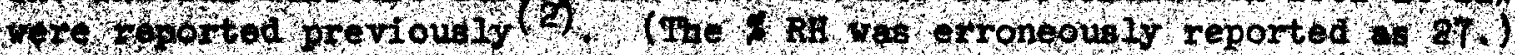

Thede dete are reported asaln together with the batence of the tost results.

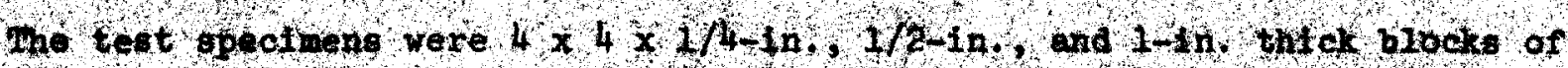
Formulation 2002, However, due to the high degree ot olmilarity between

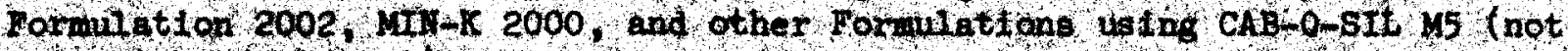

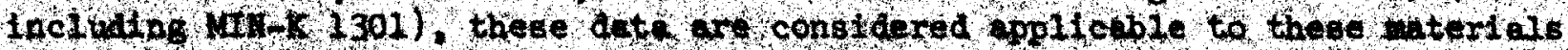

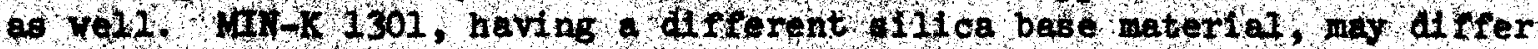
sllghtly, from formulation 2002.

The nolsture absorption tests were conducted In a sealed chamber lnto which the deblred wuidities were achieved through the use of the following supersaturated salt solutions?

$$
\begin{aligned}
& 22 \mathrm{RH}-\mathrm{CH}_{3} \mathrm{COOK} \\
& 51 \% \mathrm{RH}-\mathrm{Ca}\left(\mathrm{NO}_{3}\right)_{2}-\mathrm{HH}_{2} \mathrm{O} \\
& 91 \% \mathrm{RH}-\left(\mathrm{CH}_{3} \mathrm{COO}\right)_{2} \mathrm{Ca}
\end{aligned}
$$

These solutions, contained $1 \mathrm{n}$ small dish were placed in the chamber, and - blower wa provided to circulate the afr within the chamber. The humidity vas measured by a humldiat using the proper sensing elenents for each humidity range, and a recording hund distat for record keeping purposes. A chalnomatlo balance vas mounted direetly above the humldity chamber. The sample holder within the chamber was suspended by a fine diameter wire from the balance arm through a snall hole in the chamber. Access to the chamber for the Insertion of the samples vas provided by a hole fltted with a plastic sieeve, each end of which fone end inside the chamber, and one end outside the chember) could be sealed. To lnsert the dry (at $230 \mathrm{~F}$ to constant reight) sample lato the chamber, the operator's arm was placed into the sleeve and sealed around the upper portion of the arm. The seal inside the chamber was then opened, permitting the operator to place the dry specimen on the balance pan and to inltiate weighings.

The desorption tests were run by placing the same balance above a drying oven (operating at 230F), and suspending the belance pan into the oven. There was 


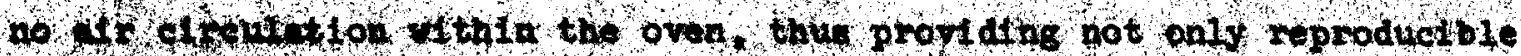

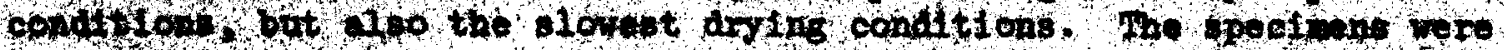

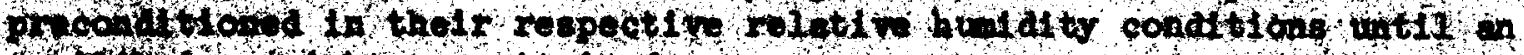

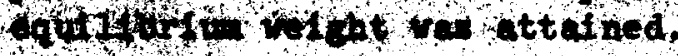

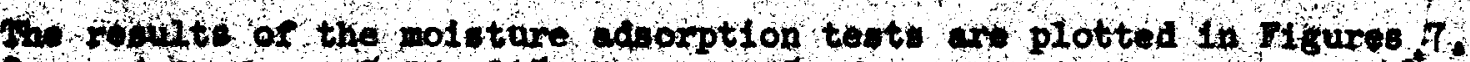

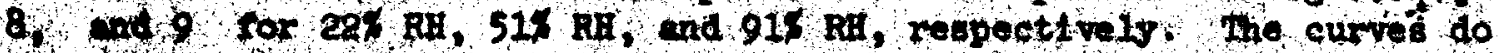

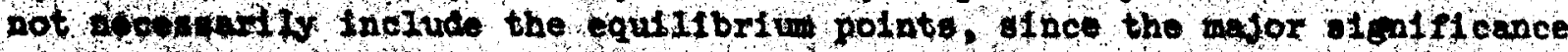
of the curves oocure in the early steres of edsorption. They elearly show the roplatty with witeh ary Wil $X$ moterials adoorb molsture from the air,

81m1ar1s. FIGire 10, 11 , and 12 represent the molsture desorption or dryins retes. In all cases, the per cent rolght change vas based upon the Initial refight of the sample. Thus, on a per cent basis, the molsture pickup during adsorption nay appear to be greater than the amount of molsture driven off $t 230$ f during desorption.

Prior to the desorption tests, all specimens were placed in a desicator contalning the proper salt solution until equilibriun was attained. In two Ins tenees, $91 \% \mathrm{RH}$ equilibri un appeared alfficult to schleve in the $1 / 4-1 \mathrm{n}$. and $1-1 \mathrm{n}$. thick specimens. Consequently, these two specimens vere placed In $100 \%$ RA conditions for 3 and 5 days (1/4-in. and $1-$ in., respectively), and subsequentiy returned to the 918 aH condition. Equilibrium was subsequathy achleved in 5 and 6 deys, respectively. Table 10 sumerizes the equifibritu wolature contents for each thickness and at each humidity level.

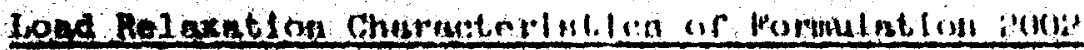

The lold relexption evaluation of Formulation 2002 at $1400 \mathrm{~F}$ hot face has been copleted st the $50 \mathrm{psi}, 100 \mathrm{psi}$, and $150 \mathrm{psi}$ initial stress levels. As prealeted in Flgure 7 or the Third Quarterly Report, the stress on the -pactive ster $2000 \mathrm{br}$ was 45 to 55 per oent of the inftial stress. No apparant relationihip between initial stress, and fraction of initial stress arter $2000 \mathrm{hr}$ could be detected, posslbly because of the slight compressibility factor of the rurnaces themselves. The spread of all the data points 18 encompased by the crosshatched band in Figure 13.

Also shown in Figure 13 are the losd relaxation characteristics of Formulation 2002 at room temperature and at 100 and $150 \mathrm{ps} 1$ initial stress levels. For these tests, the furnace was removed frow the test fixture, thus ollminating the possible error due to furnace compression. Although 
FIGURE 7.

MOISTURE ADSORPTION OF FOMULATION 2002 IN 226 RH

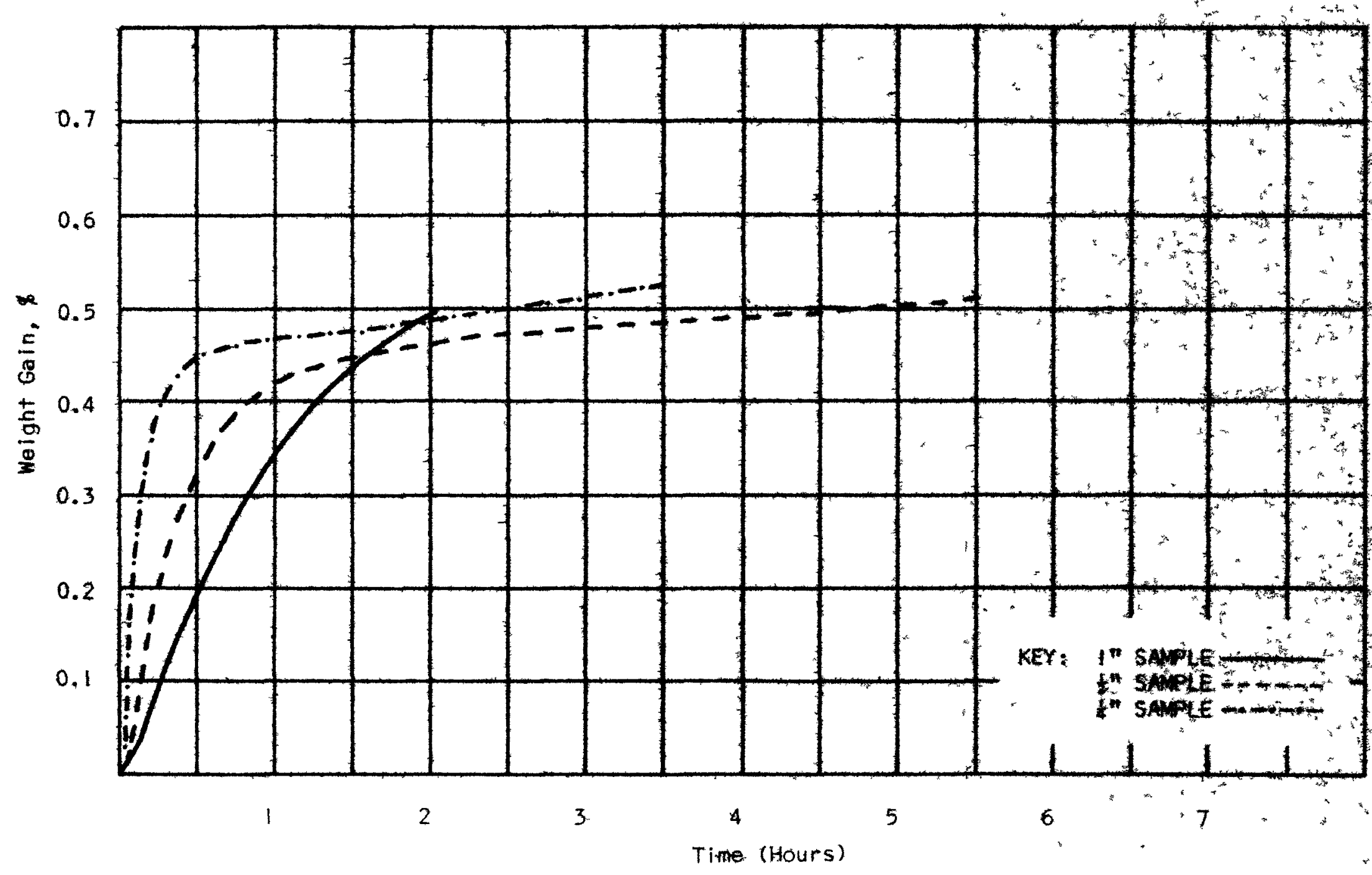


FIGURE 8.

MOISTURE ADSORPTION OF FOPMULATION 2002 IN $518 \mathrm{PH}$

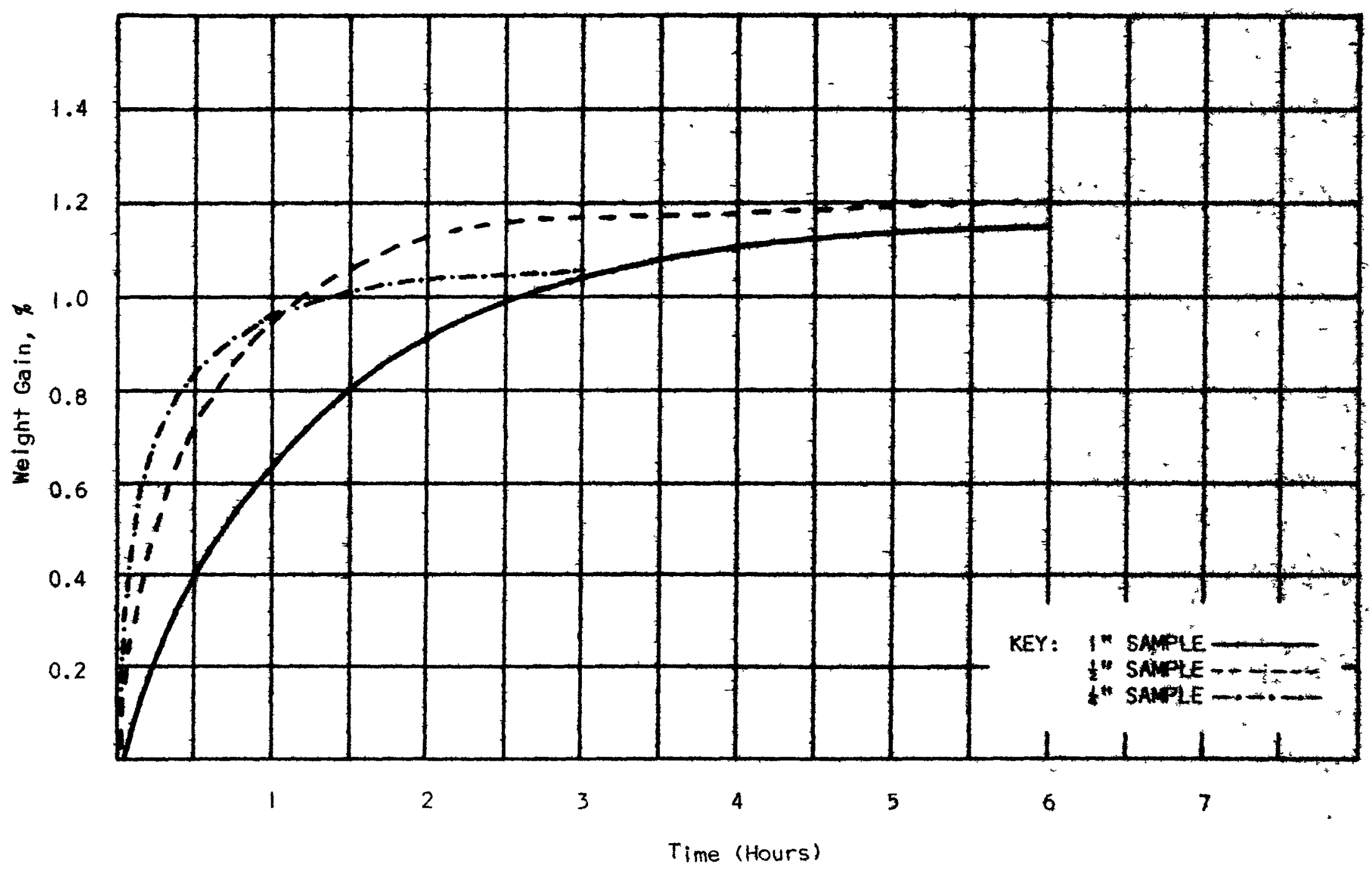


FIGURE 9.

MOISTURE NOSOAPTION OF FOMULATION 2002 IM 918 RH

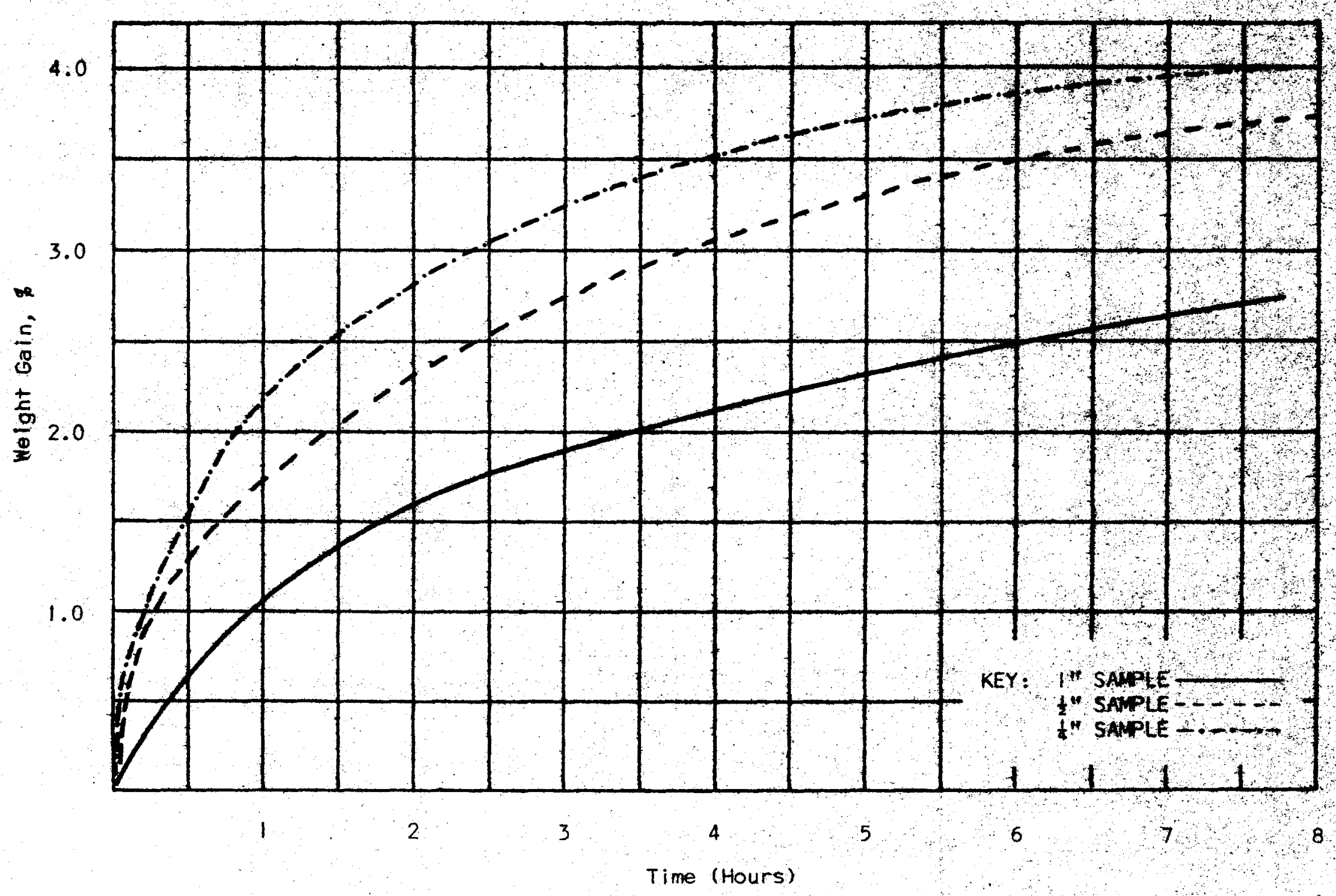




\section{FIGURE 10.}

MOISTURE DESORPTION OF FORMUEATION 2002 AFTER CONOITIONING AT $22 \%$ RH

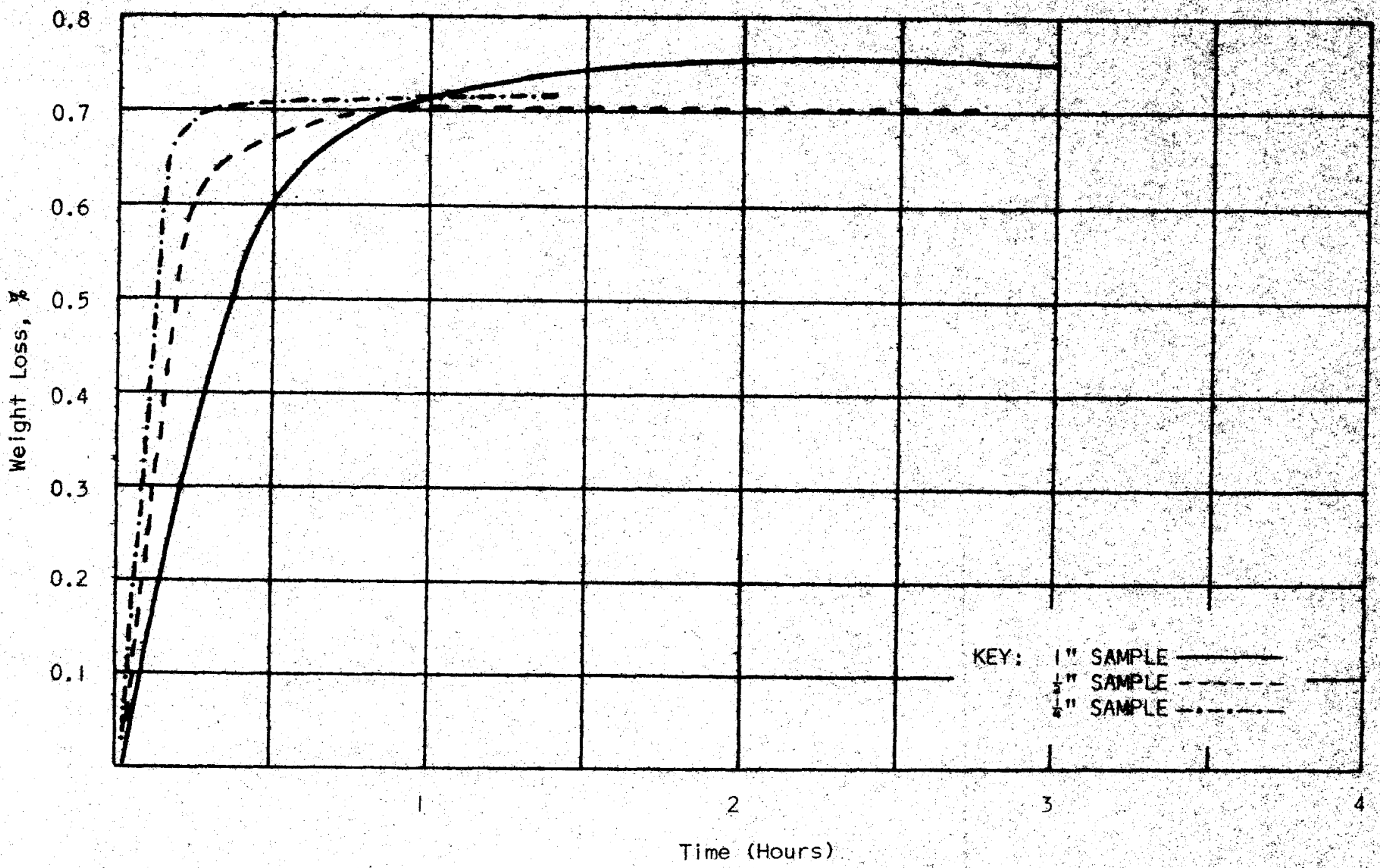


FIGURE 11 .

MOI STURE DESORPTION OF FORMULATIOA 2002

AFTER CONDITIONING AT $51 \&$ RH

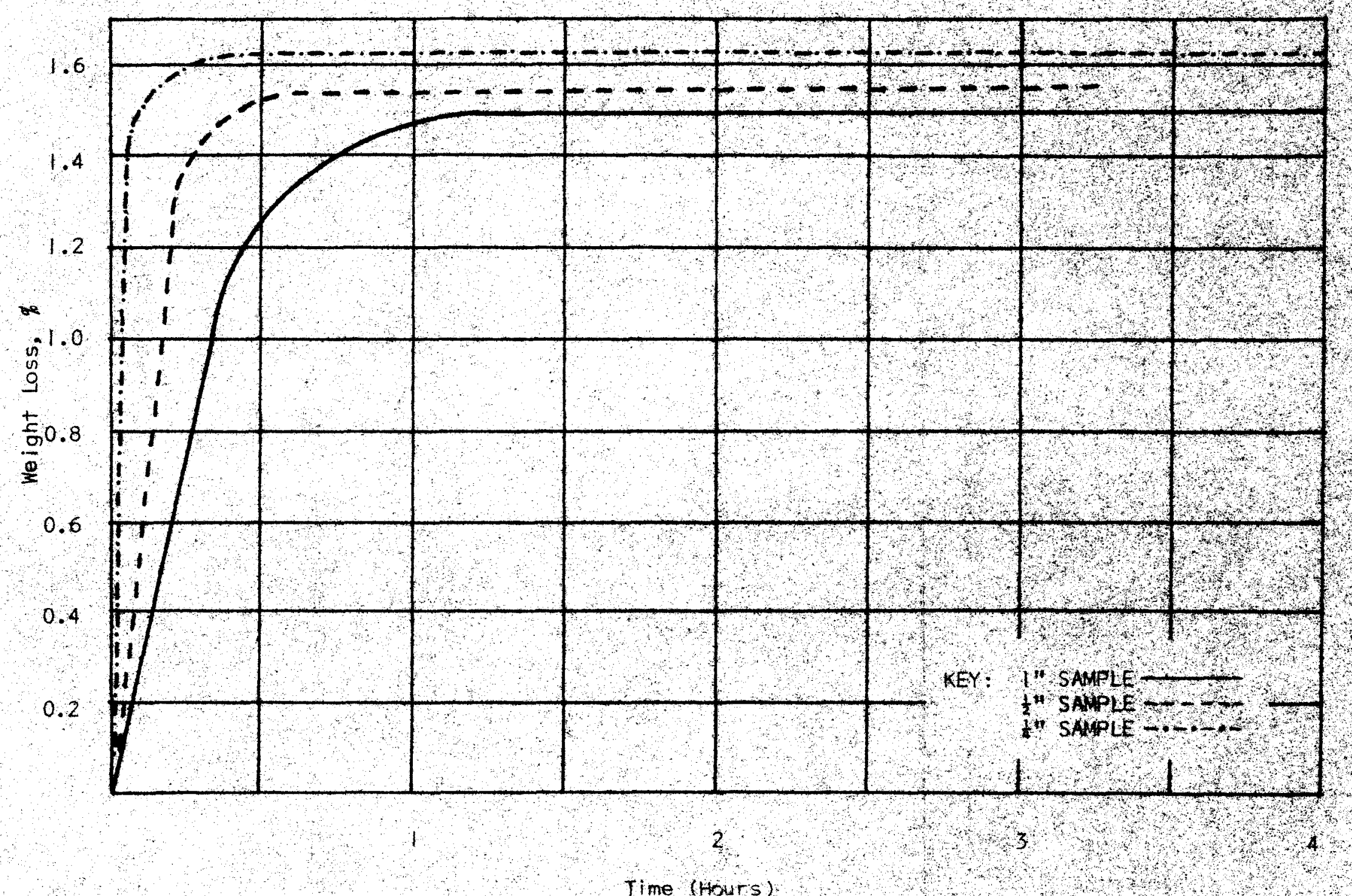

Ho

Time (Hours) 
FIGURE 12

MOISTURE DESOFPTION OF FOAMUATION 2002 AFTER CONDITIONING AT 914 RH

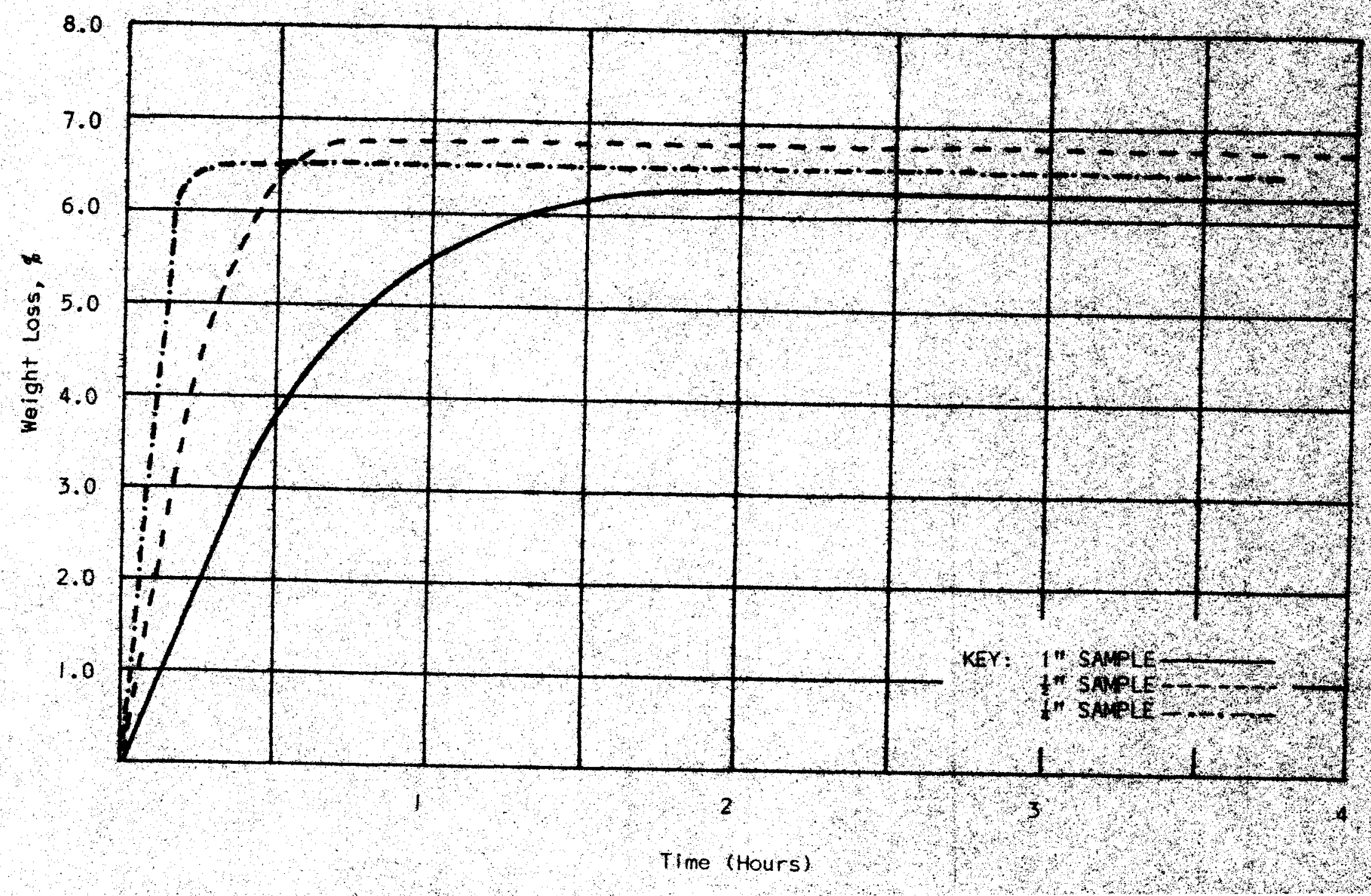


W

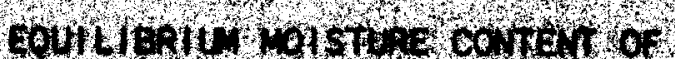

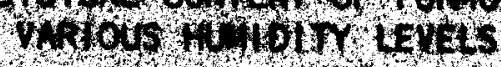

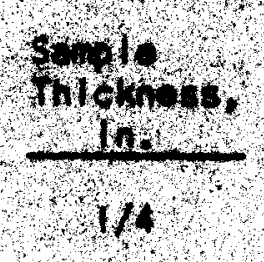

$1 / 2$

I

$1 / 4$

$1 / 2$

$$
1
$$

$1 / 4$

$1 / 2$

1

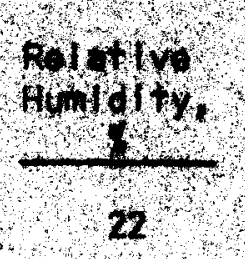

22

22

51

5.

51

91

91

91

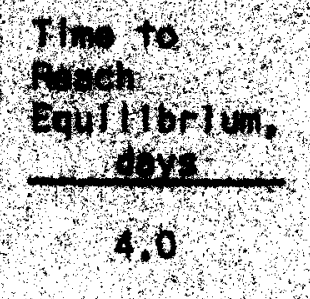

7.5

1.0

5.0

7.0

7.5

1.48

$7.1^{*}$

19.0

7.3

$6.8^{*}$ 
FIGURE 13.

LOAD RELAXATION OF FORMULATION 2002

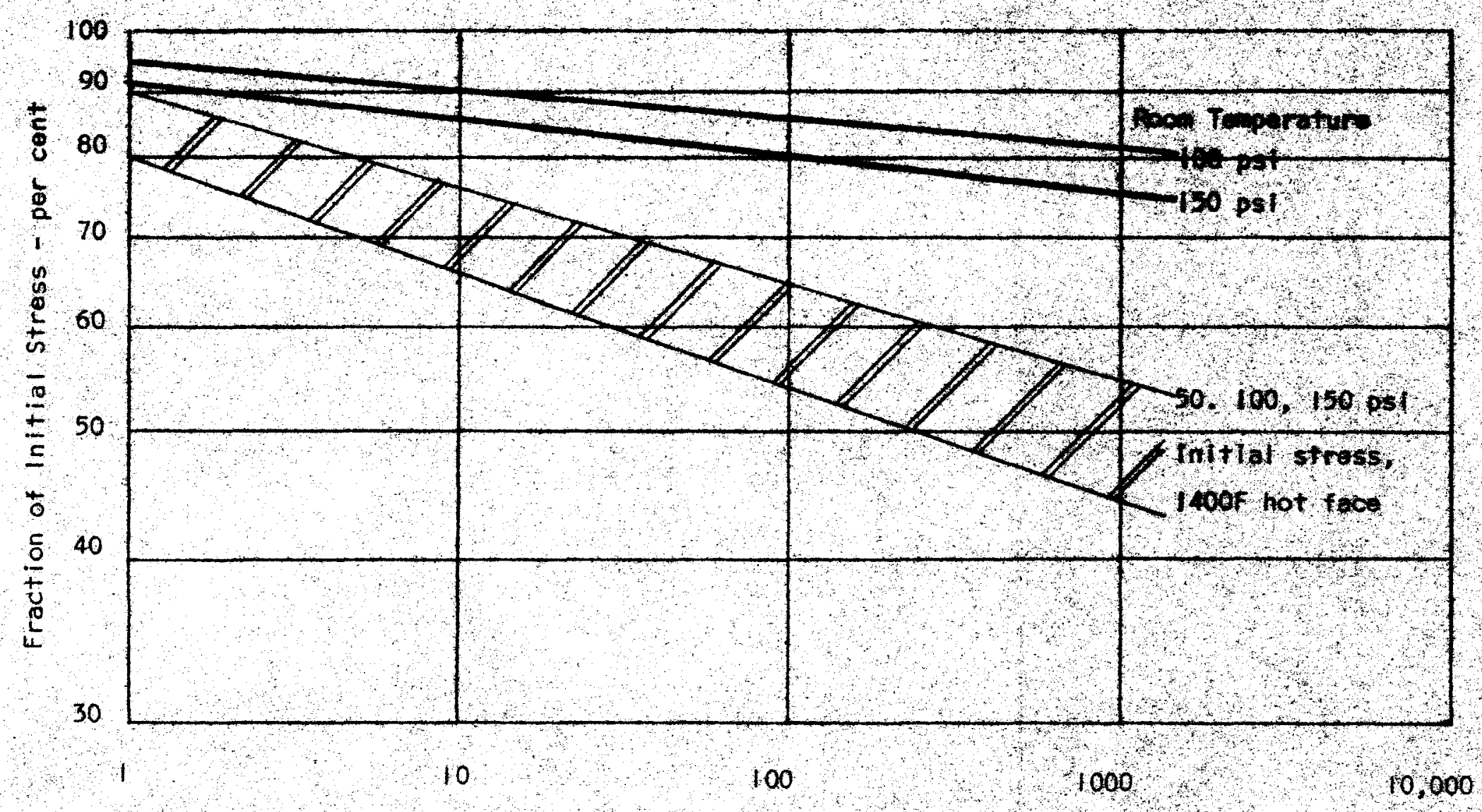

Time - Hours 

FIGURE 14:

THERMAL CONDUCTI VITT IN AIR OF FOAMHLATIONS 1999 NNO 2002

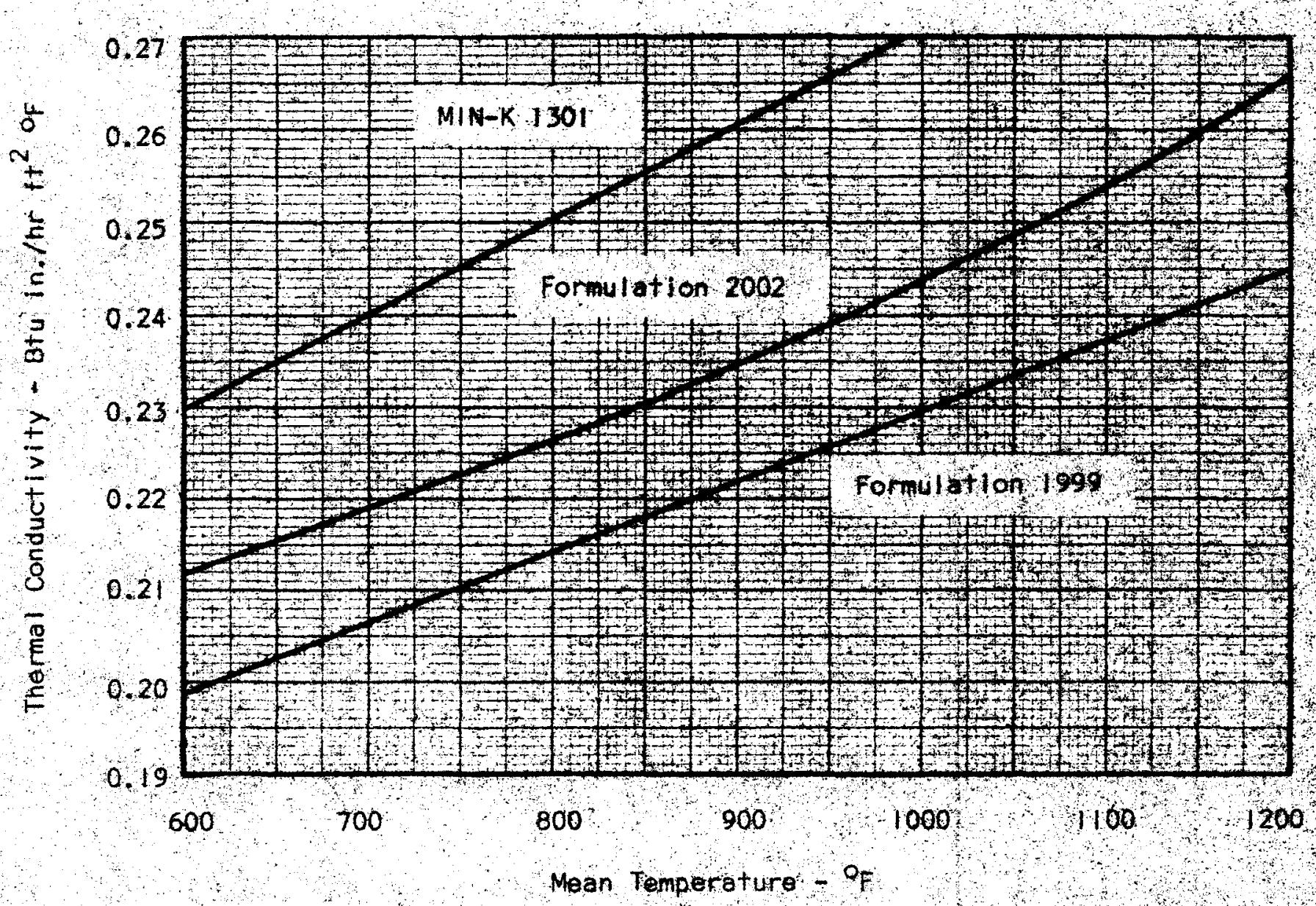




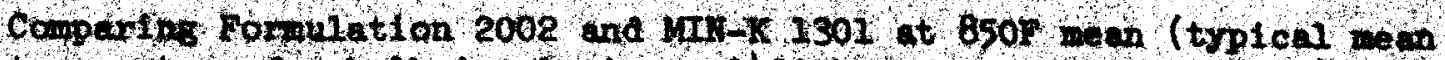
temperature of bulk ina ulati on - 1400 hot foee, 300 cold face). Formilation

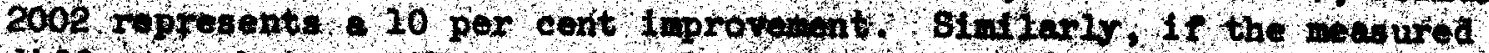
dfrerence between the tvo formulations 18 elignificant, formulation 1999 represents a 4 per cent lmprovenont at 6507 wean (trplcal module in an

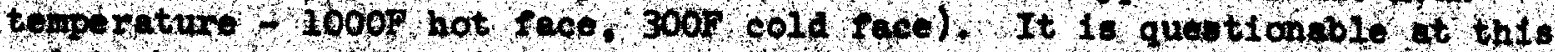
polnt, hovever, $1 \mathrm{r}$ an increase $1 \mathrm{~h}$ efflclency of wore then 10 per cent could be antlolpated.

\section{Shear Btrength of Formulation 2002}

2o conflrm the relative weakness of formulation 2002 in shear paraliel to Its laminar plane, 12 speclineps tore subjected to shear at room temperature. The test utilizea $1 \times 2 \times 3 / 4-1 n$. opecimens whtch ware placed on thelr $2 \times 3 / 4-1 n$. edse vithin a confining fixture. The flxture was so constructed as to prevent an movement of half of the projected aren, or $2 \times 3 / 8 \mathrm{ln}$, While the remaining halp wa ubjected to a guillotine action over its entire area at a lodding rate of $50 \mathrm{lo} / \mathrm{min}$ (or approximately $37.5 \mathrm{psi} / \mathrm{min}$ ).

An average value of 22.1 psi was obtalned for the 12 specimens, with an approximete spread of \pm 25 per cent for the Individual values. frevious vork on WMN-K 1301 contalning binder resulted in an average of 44 psi, with a higher spread of values. Although no date exiot for a direct comparison, It would be anticipated that MIN-K 1301 with the binder removed would have a shear strength approximating that of Formulation 2002. Thus, as expected, Forwulation 2002 does not represent a signiflcant change in shear strength from the current MII-K 1301 matertal, and hence, should not be requi red to oustain excessive shear forces during service.

\section{B. SILIOON-GERMANIUM INSULATIONS}

\section{Ohemeal Compatibility}

The chemical compatibility between $N$ and $P$ silicon-germani um elements and the four fibrous Insulation candidates (Irish RHRRABIL, MICRO-QUAPTZ, ASTROQUARTZ, and DYNAQUARTZ) was determined by embedding a seriea of cylindrical elements $(0.444$ in. diemeter by 0.271 in. long) into each insulation and subjecting them to $1600 \mathrm{~F}$ isothermal conditions in al $r$ and vacuum (1ess than 2 mferons). Perlodically, several of the elements vere removed frow the finsulation, and appraximately 5 mg removed uniformly from the cyllndrical surface of each element. The powder thus obtained was then analyzed spectrographically for impurities. Since the procedure specifically evaluated the surface contamination, the analys is was qualitative only. 

TABLE 12

\section{SIC, DOMPATIBILINY IN AIR AT I600F}

\section{Flbrous Product \\ Trtsh REFAsIL \\ $500 \mathrm{hr}$ \\ $1000 \mathrm{hr}$ \\ $1500 \mathrm{hr}$ \\ $2000 \mathrm{hr}$}

ASTROQUARTZ

$500 \mathrm{hr}$

$1000 \mathrm{hr}$

$1500 \mathrm{hr}$

$2000 \mathrm{hr}$

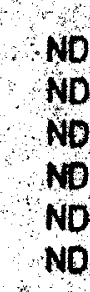

\begin{tabular}{|c|c|c|c|c|c|c|}
\hline NO & t. $\quad t_{0}$ & NO & ND & ND & ND. & ND \\
\hline $\mathrm{ND}$ & t. & No & ND & ND &.+ & ND \\
\hline ND &.+ & y.s. & ND & ND & ND & t. \\
\hline ND & V.s. s. & No & ND & NO & NO & NO \\
\hline ND & V.S. & NO & ND & ND & ND & NO \\
\hline NO & V.S., V.S. & 10 & NO & NQ & ND & No \\
\hline
\end{tabular}

lomelity in sise Eloments

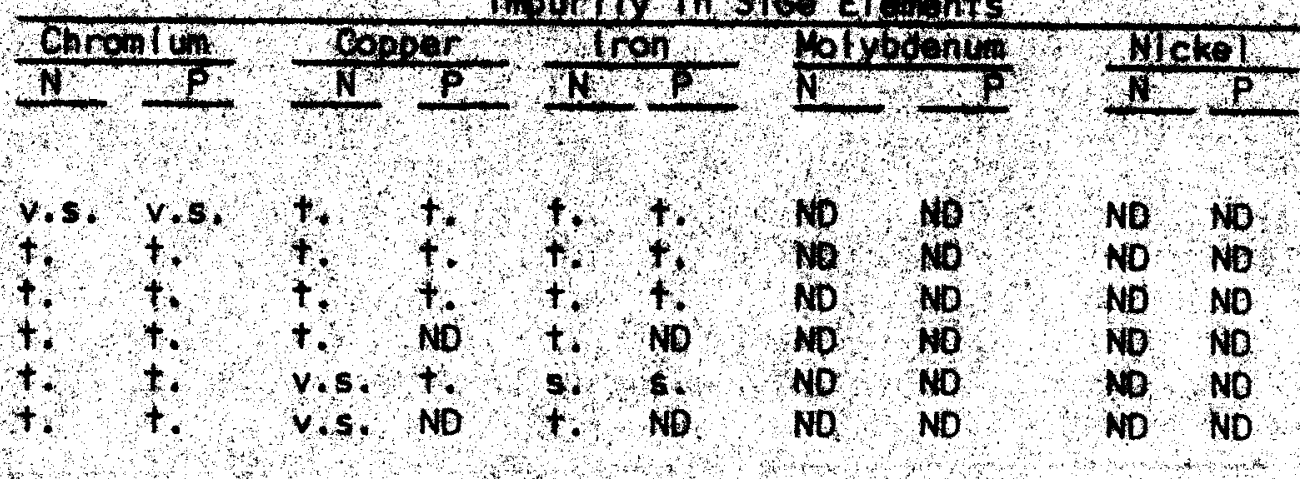

\begin{tabular}{|c|c|c|c|c|c|c|c|c|c|}
\hline ND & ND & t. & s. & No & ND & ND & ND & ND & ND \\
\hline NO & NO & t. & V.s. & t. & t. & NO & ND & ND & ND \\
\hline NO & ND & $t$ & v.s. & t. & ND & ND. & ND & ND & $t$ \\
\hline ND & ND & v.s. & s. & ND & ND & ND & ND & AD & NO \\
\hline ND & ND & $v . s$. & s. & t. & ND & ND & ND & ND & ND \\
\hline no & ND & v.s. & 5. & ND & ND & NO & NO & ND & ND \\
\hline
\end{tabular}

DYNAQUARTZ

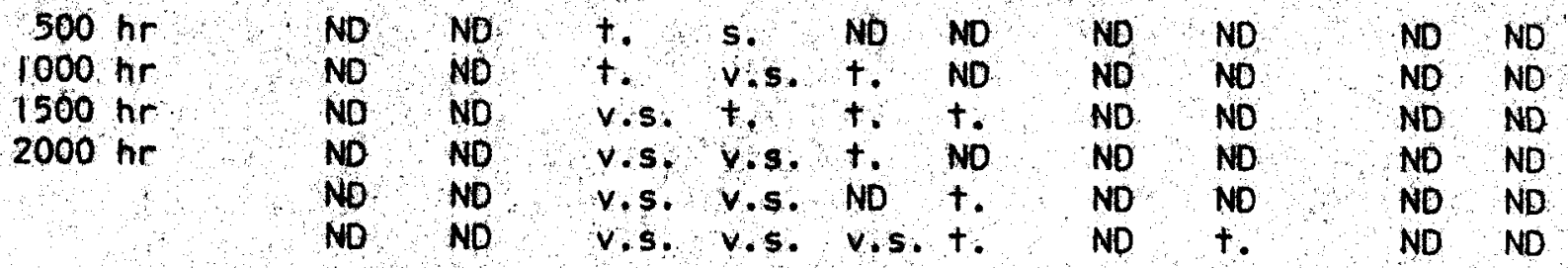

\footnotetext{
ND - not detected $-<0.001 \%$

t. - trace - <0.01\%

v.s. - very small - <0.1\%

s. - small $-<1.08$
} 



FIGURE 15

FHERMAL CONDLCTIVIT IN ALR OF IRISA REFRASIL AT 10,3 PEF ANO DTwathatz at 10.0 pCF

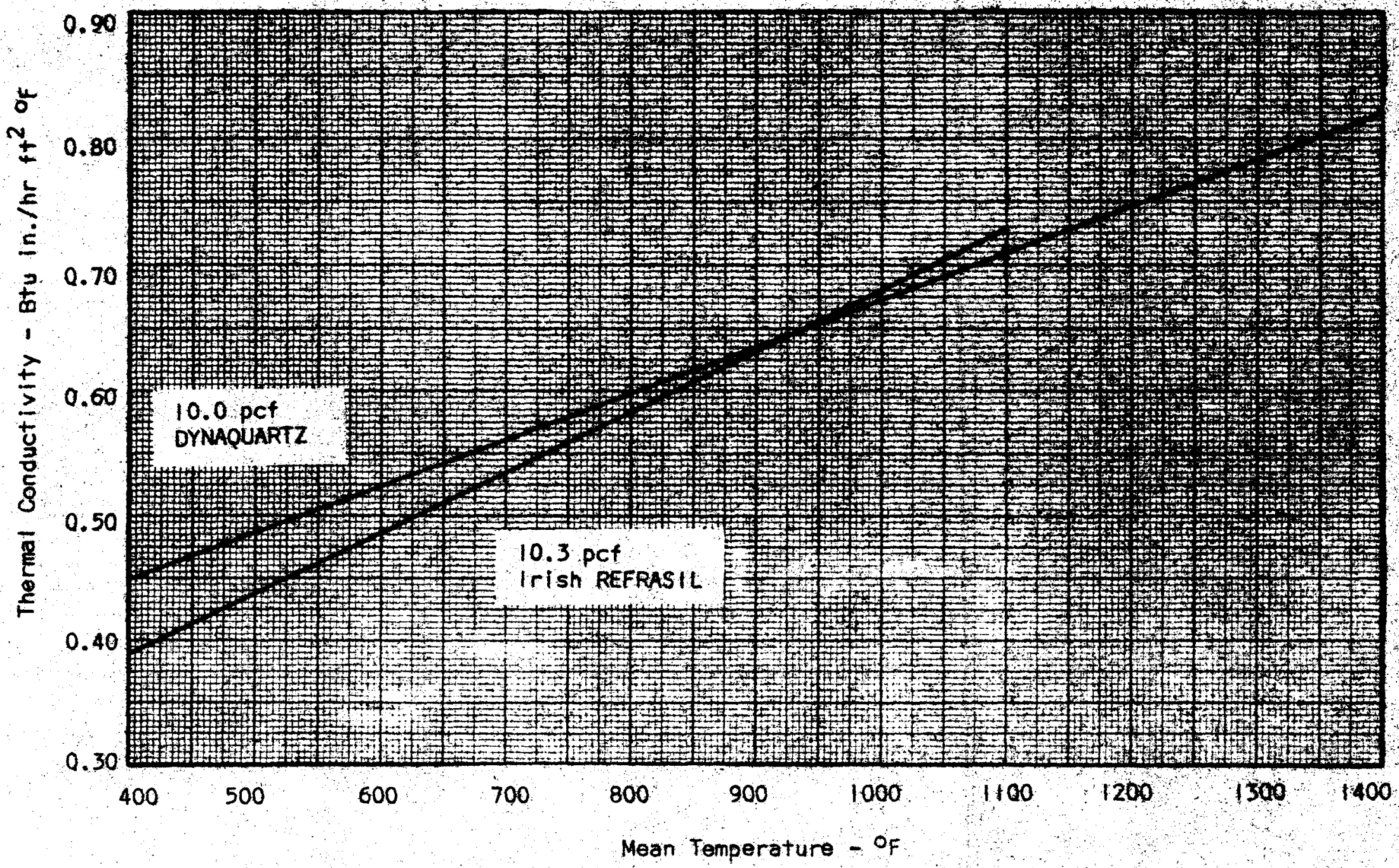



TABLE 15.

FOURTH QUARTER EXPERIMENTAL MIN-K FORMULATIONS ${ }^{\text {(I) }}$

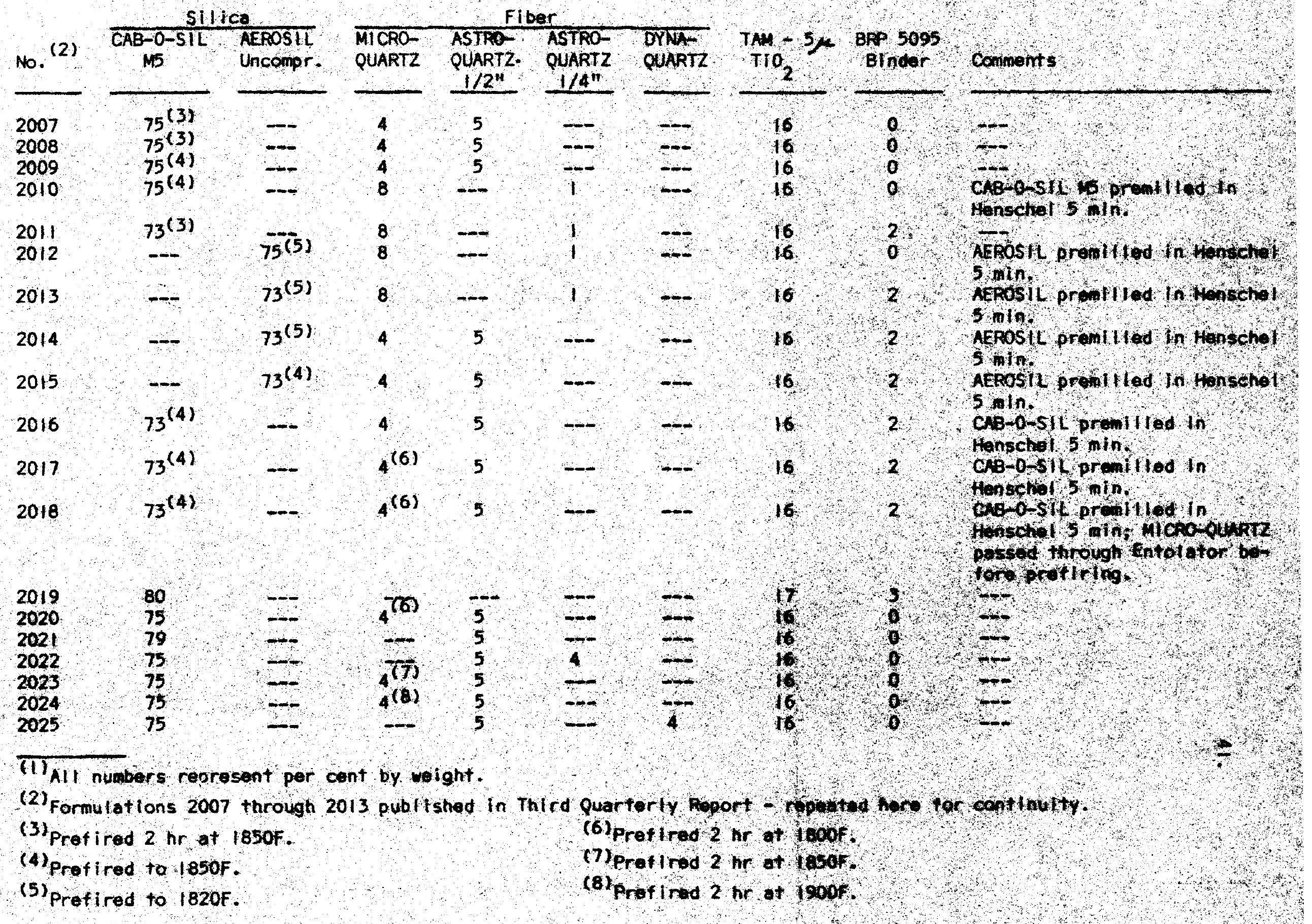


TABLE 16.

THERMA STABILITY OF EXPERMENTAL FORUULATIONS $2010-2018$

\begin{tabular}{|c|c|c|c|c|c|}
\hline No. & $\begin{array}{l}\text { Maxinum } \\
\text { Temp. OF }\end{array}$ & $\begin{array}{l}\text { Shringe } \\
\text { Length }\end{array}$ & $\frac{\text { atter }}{\text { Virth }}$ & $\frac{\text { hre e } 1600 \mathrm{~F}}{\text { Thicksess }}$ & $\begin{array}{l}\text { Maxiniun } \\
\text { Iomp. }\end{array}$ \\
\hline 1999 & 1596 & 1.5 & 1.5 & 1.1 & 1804 \\
\hline 2002 & - & 0.5 & 0.3 & 0.4 & - \\
\hline 2010 & 1605 & 1.2 & 1.2 & 0.0 & 1794 \\
\hline 2011 & - & 1.1 & 1.1 & 0.0 & 1813 \\
\hline 2012 & 1618 & 1,1 & 1,1 & 0.7 & - \\
\hline 2014 & - & 0.4 & 0.3 & 0.6 & - \\
\hline 2015 & 1591 & 0.4 & 0.4 & 0.3 & 1799 \\
\hline 2016 & 1578 & 0.4 & 0.4 & 0.5 & 1804 \\
\hline 2017 & 1605 & 0.0 & 0.0 & 0.3 & 1818 \\
\hline 2018 & - & 0.0 & 0.0 & 0.4 & - \\
\hline
\end{tabular}

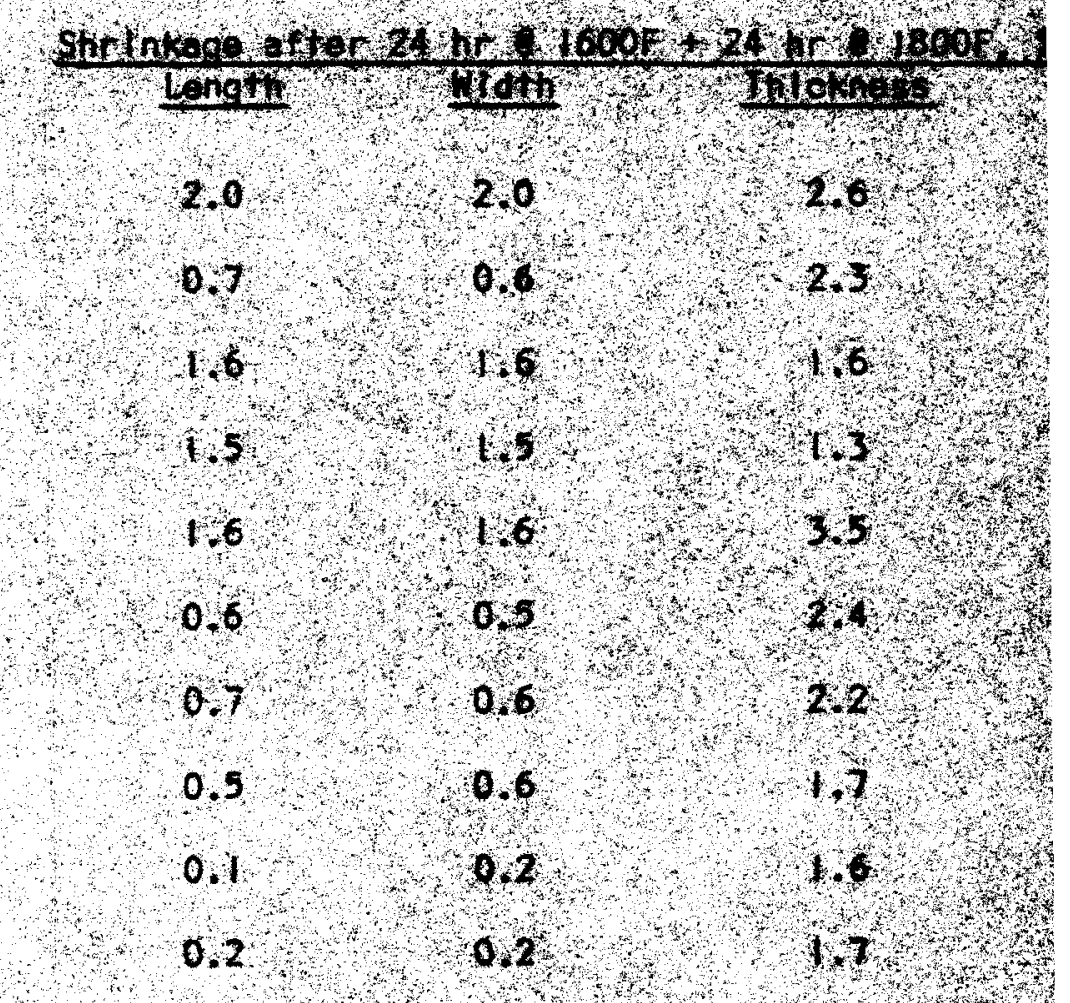





4.

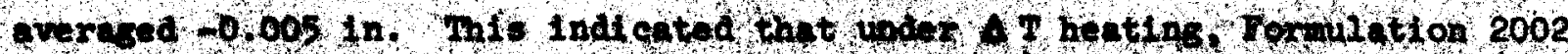

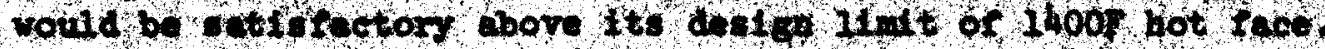

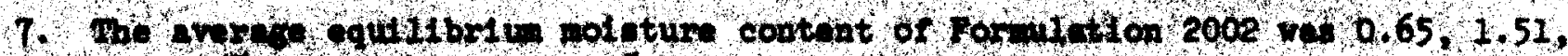

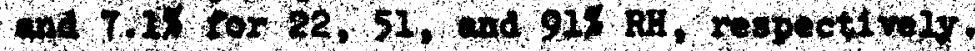

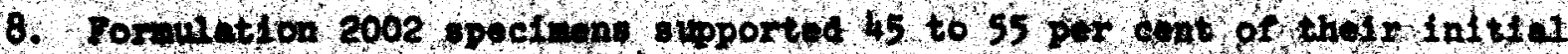

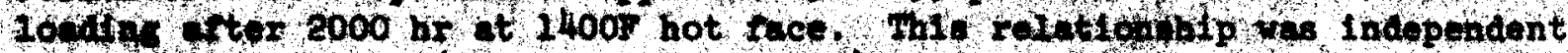
of the intter $10 \mathrm{dd}(50,100$, or 150 pat).

9. Tornut thons 1999 and 2002 hed thermal conduetivit les cpproxtantely 10 per

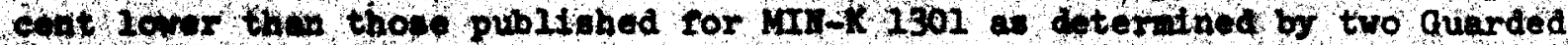
Dot Rlate Aptartives.

10. The ohoer atrength of formulation 2002 parallel to the faminar direction arorted 22.1 pil.

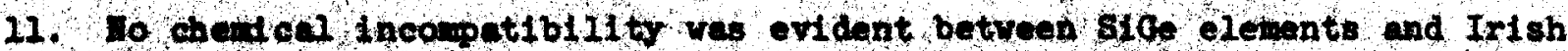
RHAMST, NTCRO-QUART, ASTROQUARTZ, and DMMQUARTZ after $2000 \mathrm{hr}$ in alr at 16005. S1ml larly, no Ineompatibility vas evident arter $500 \mathrm{hr}$ in vacum

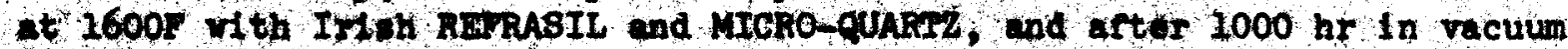

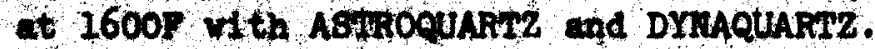

12. Inth RERUBIL ( 10 pcf) and DMuQuARTz ( 10 pof) had similar thermal conduetivities of 0.65 Btu in. $/ \mathrm{hr} \mathrm{ft}^{2}$ of at $950 \mathrm{~F}$ hewn.

\section{MATERIAL AND PROCESS DEVELOPMENT}

1. AWhostL uneompested showed no greater thermal stibilfty than CAB-O-SIU MS.

2. Formulations contalning preflred CAB-0-SIL M5 required binder to obtain a soved molding, although the reaultant product vas more stable than those unling infI rad CAB-O-SIL US.

3. Profirine the IICRO-quARz reduced the shrinkage of the products.

4. A sfonle cent loss in strength vas noted in Formulations containing MICRO-quARTz which was prefired above $1850 \mathrm{~F}$.

5. Formulation 2020 was chosen os the material for $1800 \mathrm{~F}$ service after consideration of several trade-off feotors. 




\section{\$. 9 mingen}

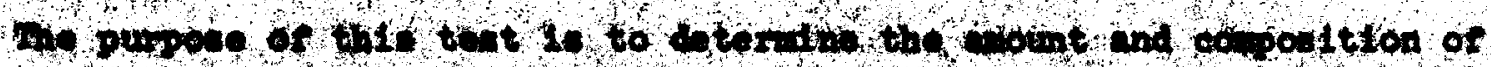

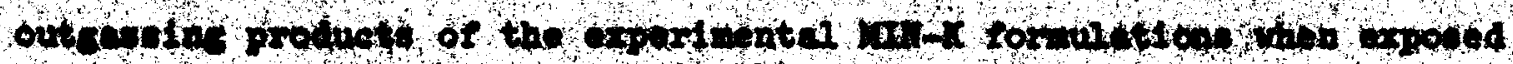

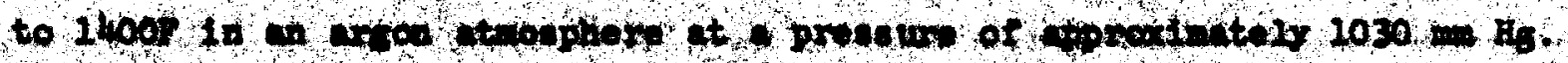

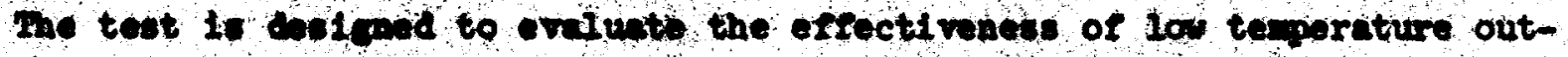

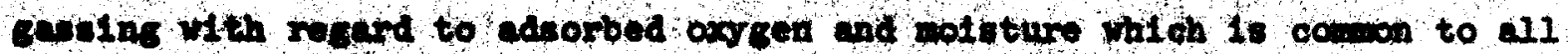

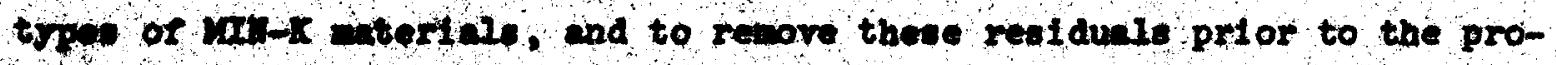
longed tontine if noconery.

\subsection{Ens Dnt}

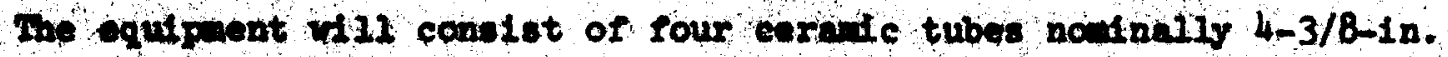
alewer by 30-1n. Ions, each havins the following attechuonts:

1. Tror or of lal lar gasket and flange assembly for sealipg tube.

2. Valved gae inlet port (for Introduction of argon) with 0 to 2 etmosphere cane ettached for reading poiltive argon pressuro within tube.

3. One und ono-half linch denoter vacuid ralve with flenge for connecting to recuim puro system.

4. BIenk IInge vith 1/4-in. valve attached. (ThIs flange wil be connected to the vecum Innge (Itew 3) upon completion of all evacuation and backfll cycles for pertodic gas ampling.)

5. Arcon bottle end tatnless oteel-copper manifold system leading to ce Inlet port (Item ?). The argon If whe rll renaln connected throughout the prolonged portion of the test. The four tubes 1121 be placed

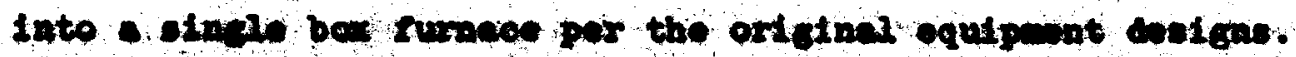










Y.

\section{TTEd of DNats}

2.1.

1...

Pa.

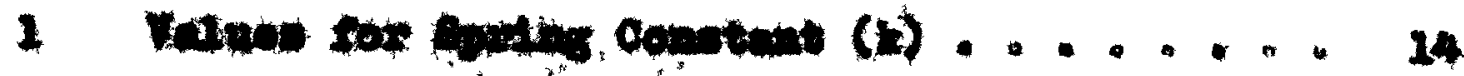

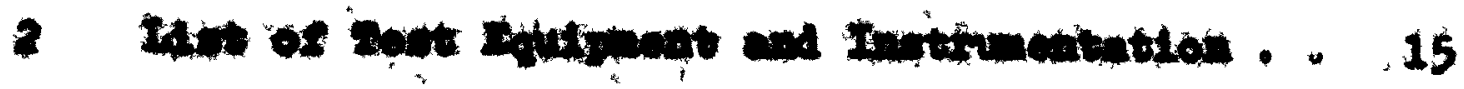



I. Axpoptor.

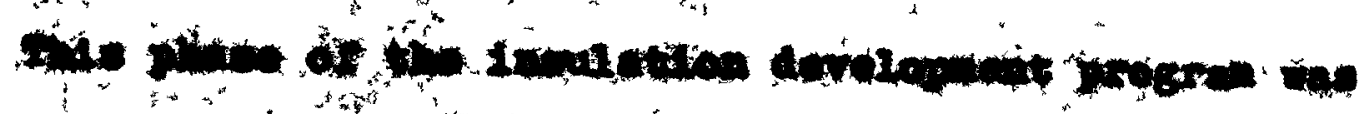

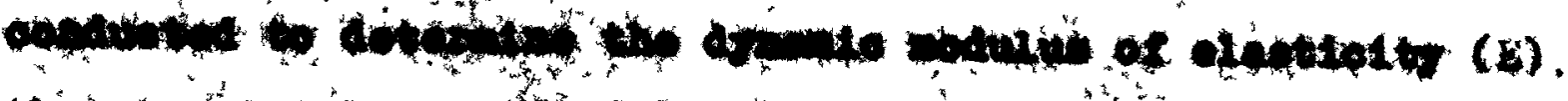

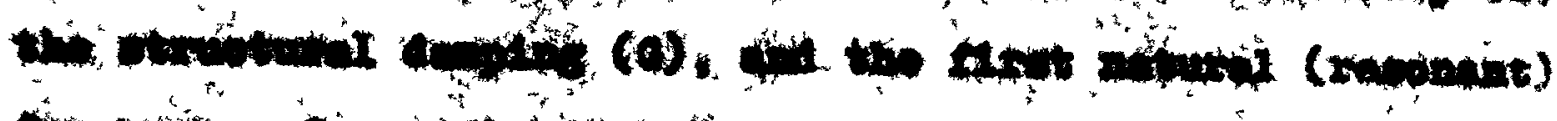

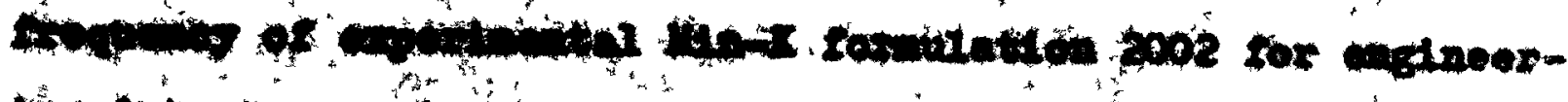

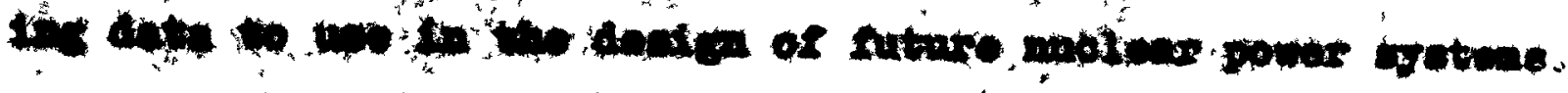

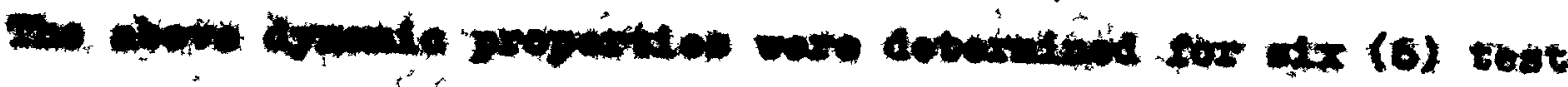

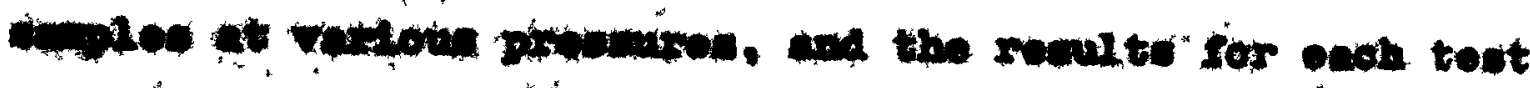

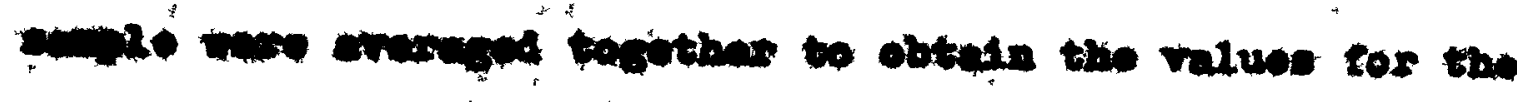

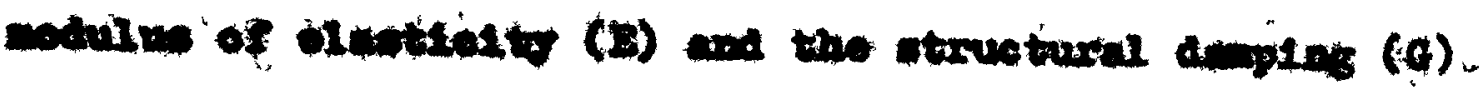




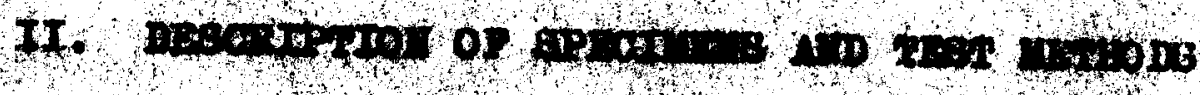

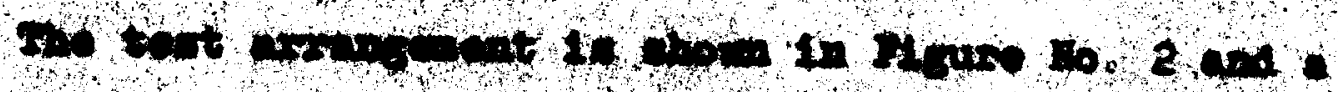

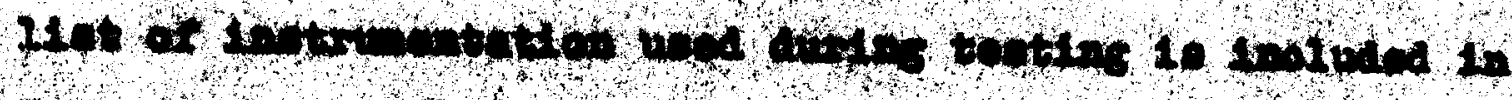

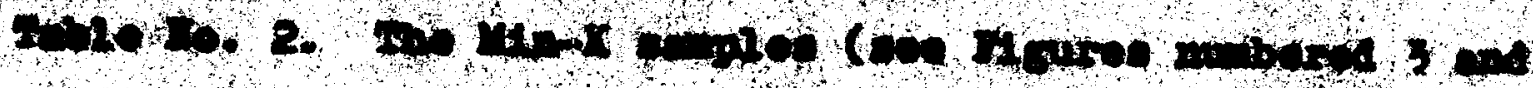

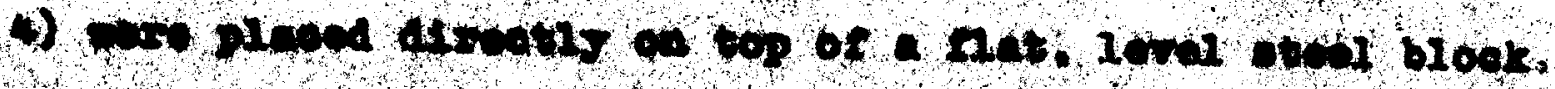

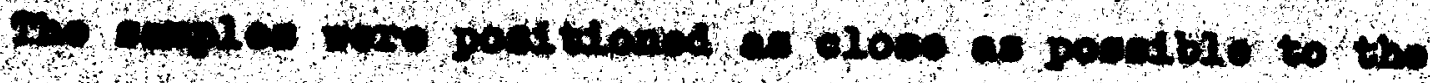

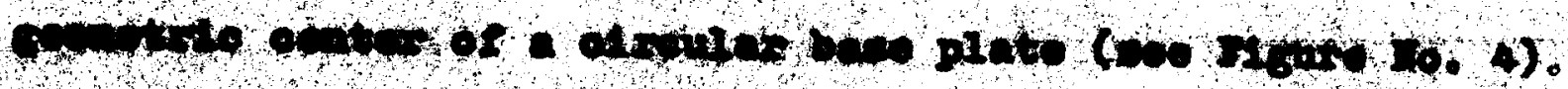

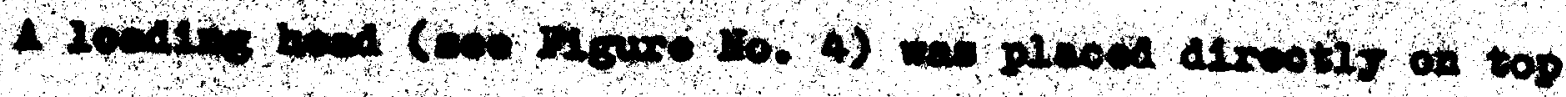

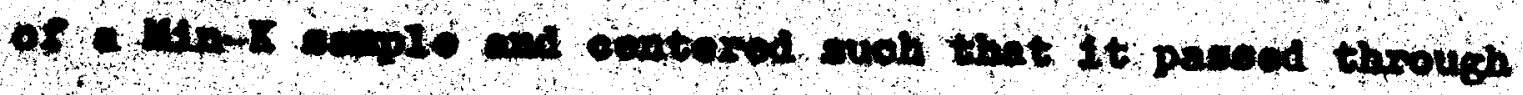

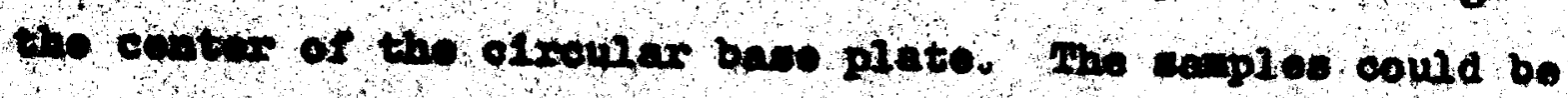

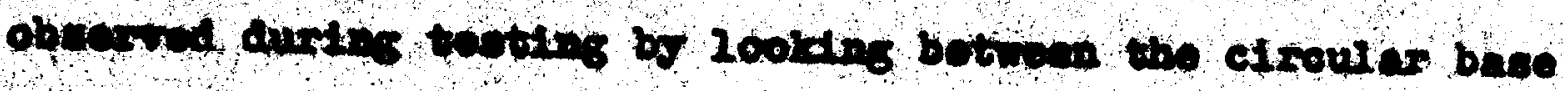
Nute on the noor.

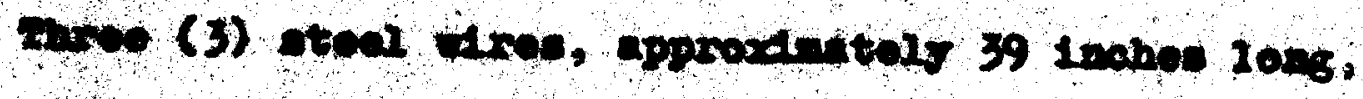

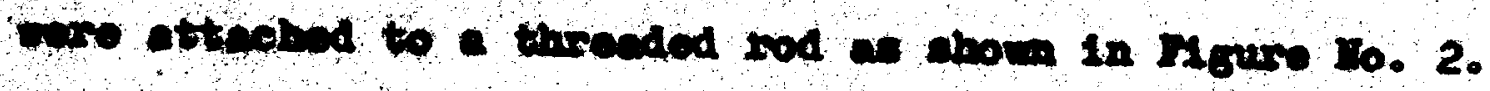

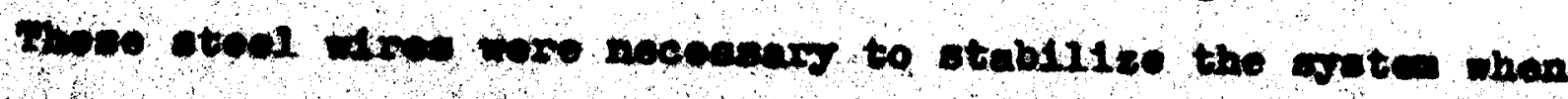

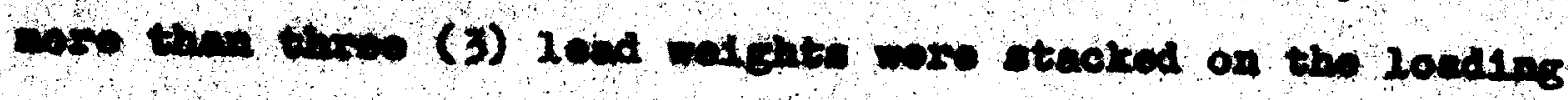

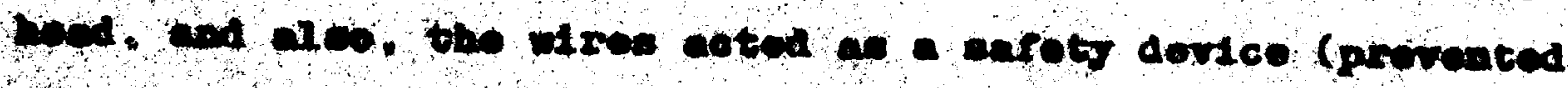

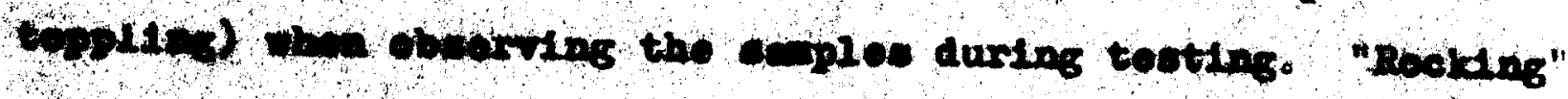

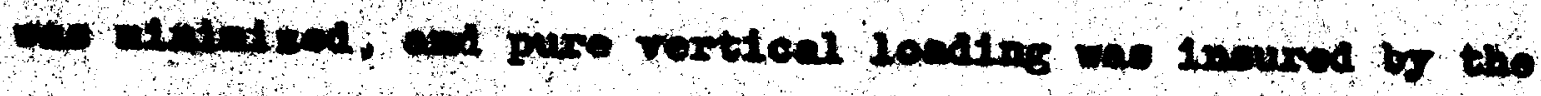

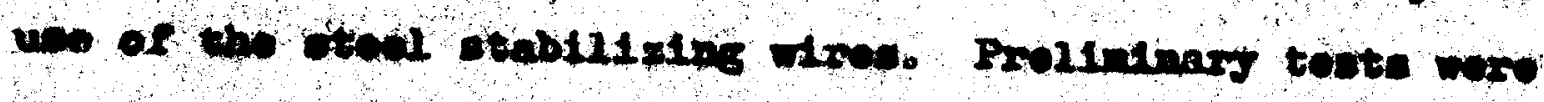

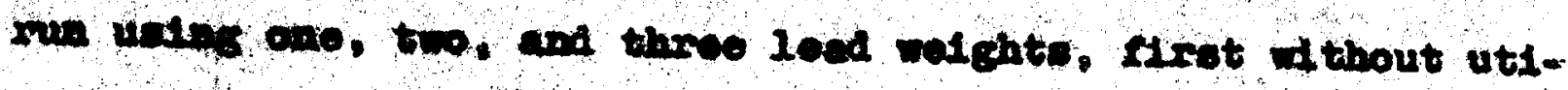

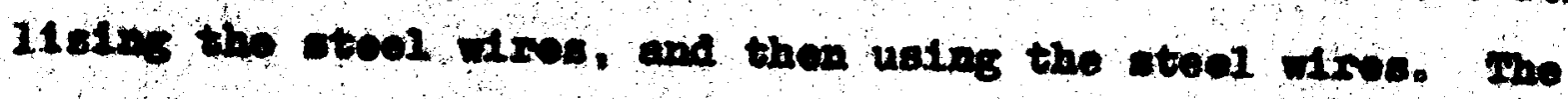

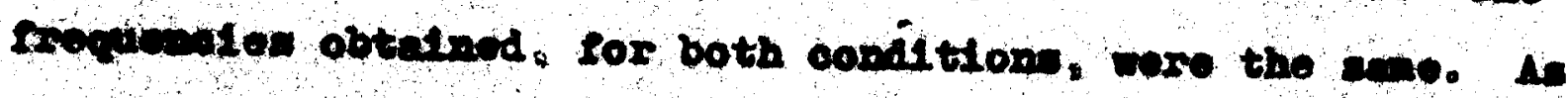
a soute of thoes proliningy toote, it was decldad that tho 


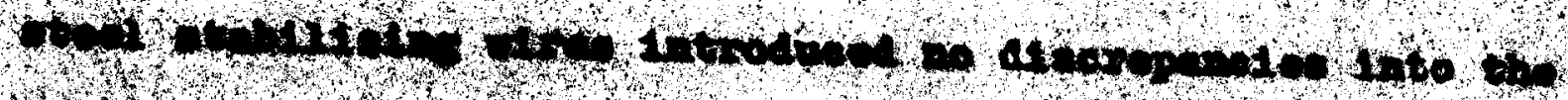
$\left(x^{3}\right)$

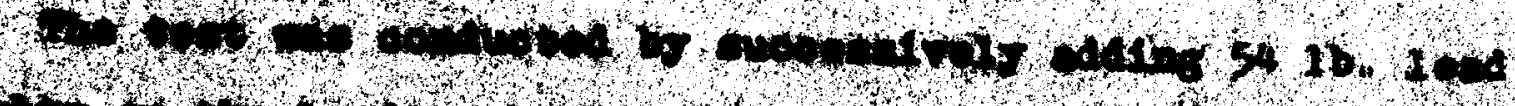

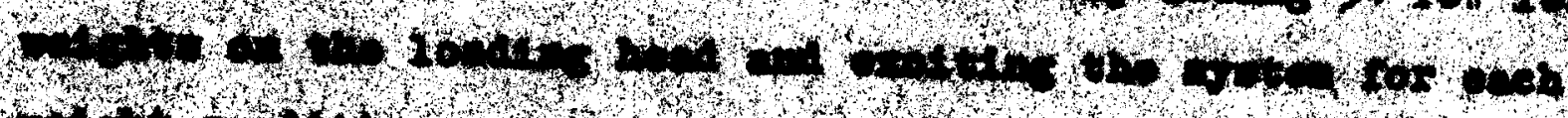

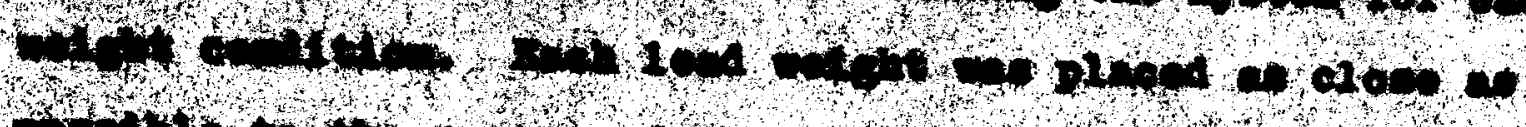

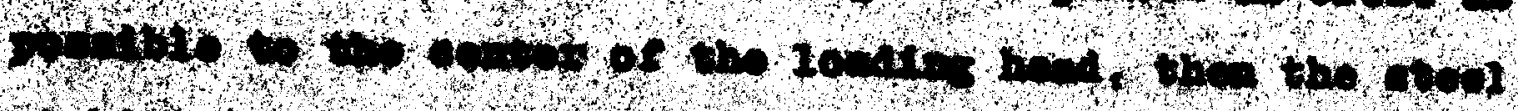

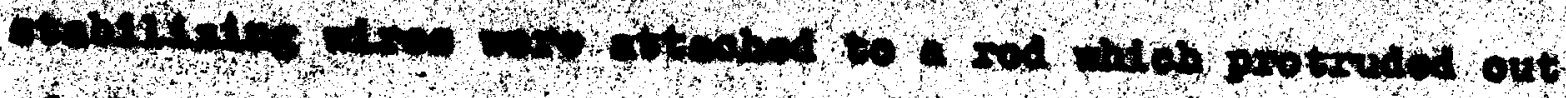

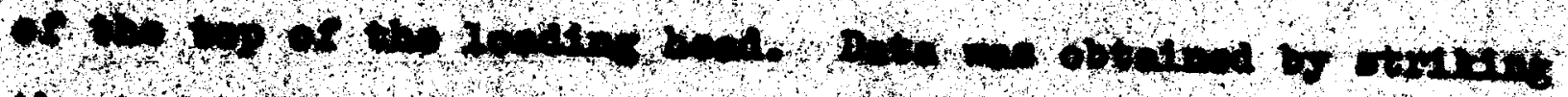

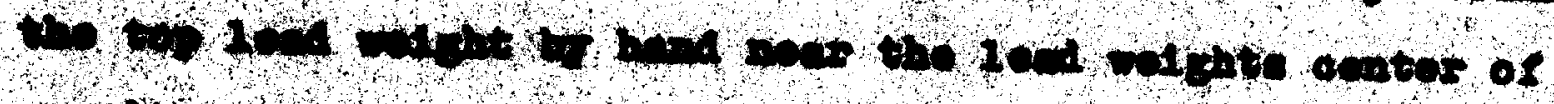

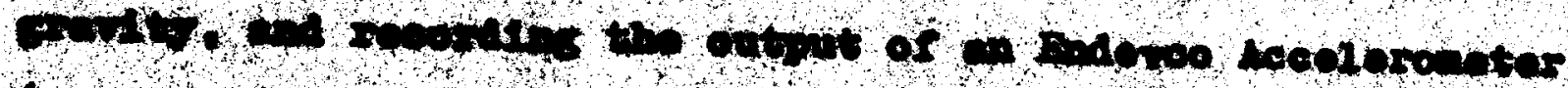

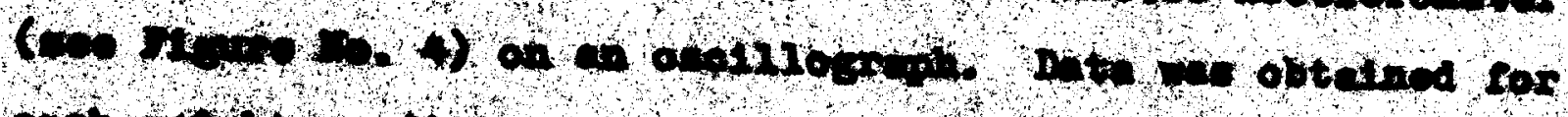

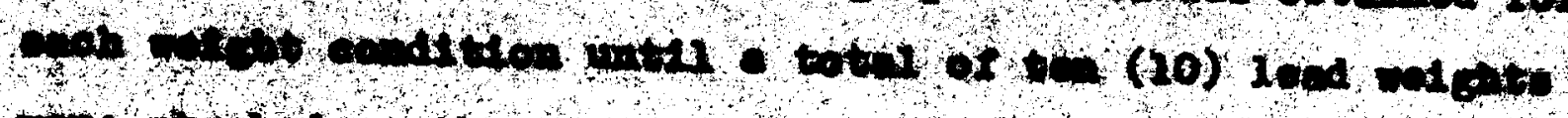

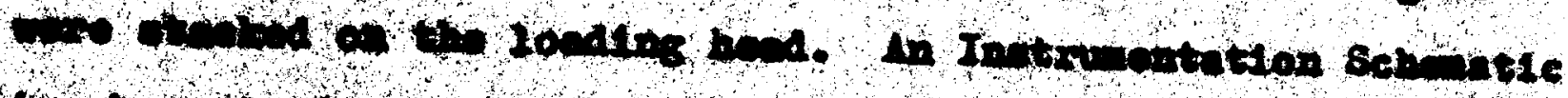
$14+4,4,0,5$.

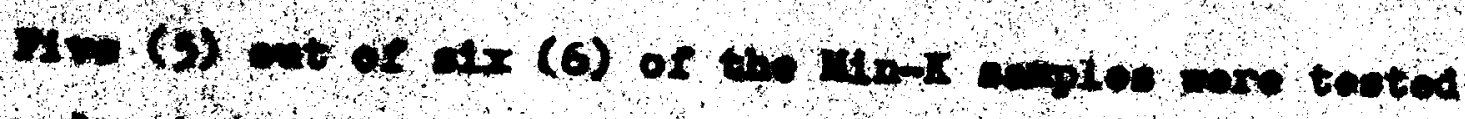

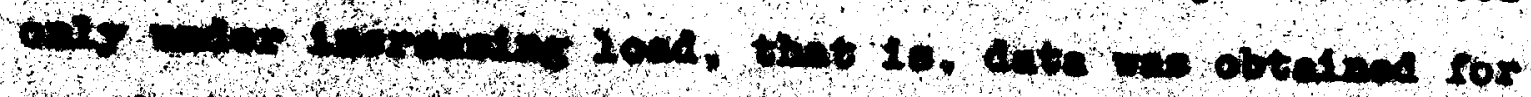

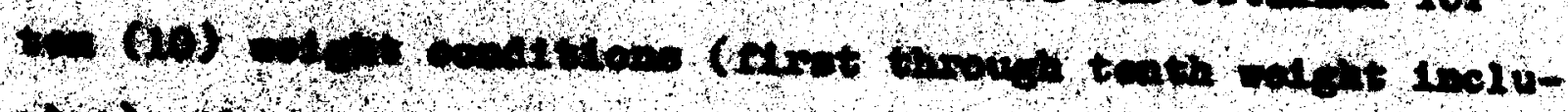

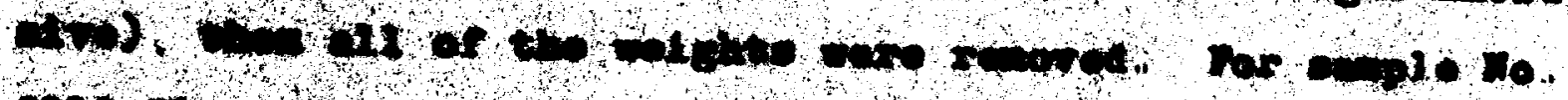

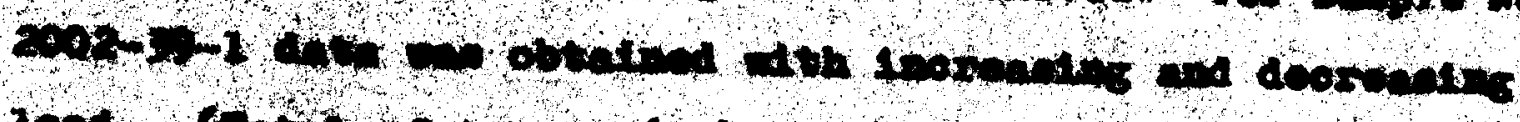

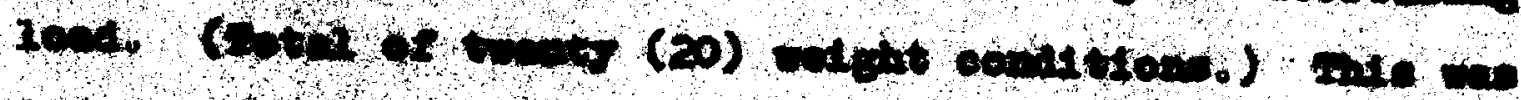

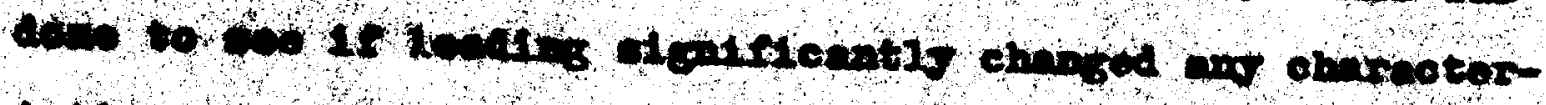

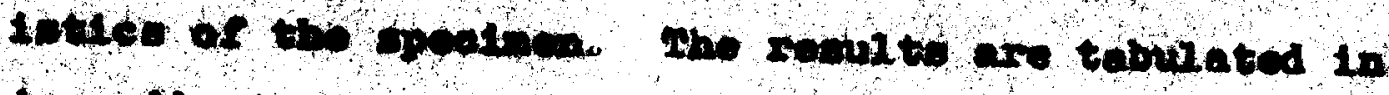
Apendis. 


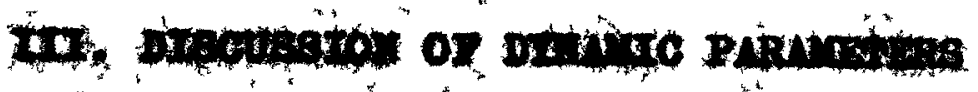

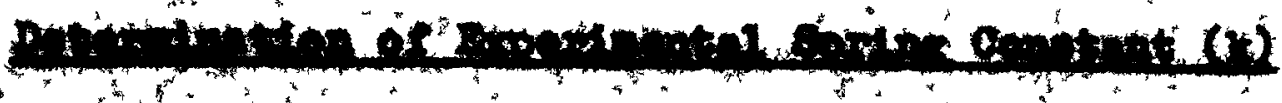

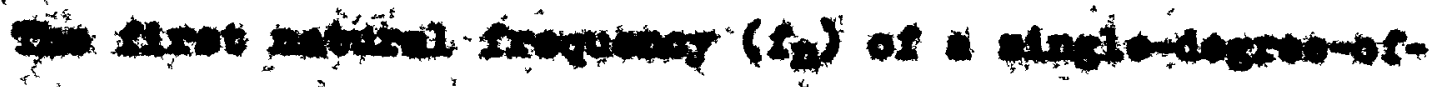

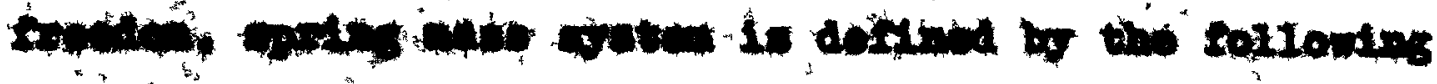
apinger

$-\frac{2}{2} \sqrt{2}$

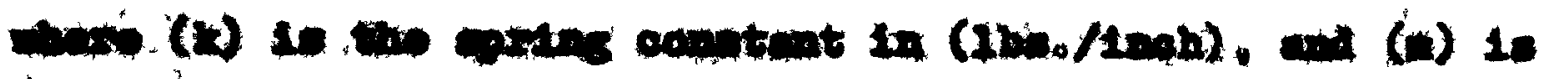

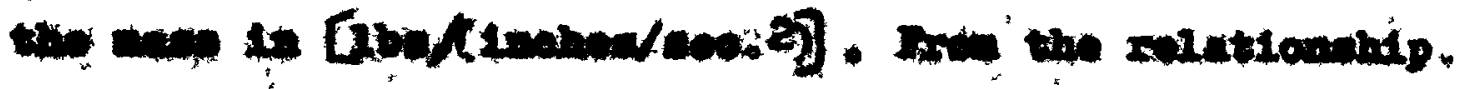
$=-2 / 6$,

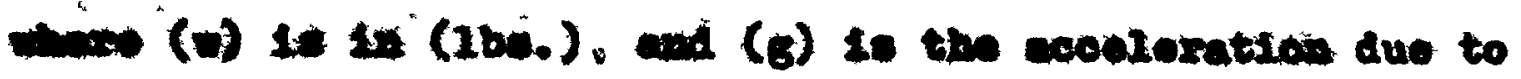

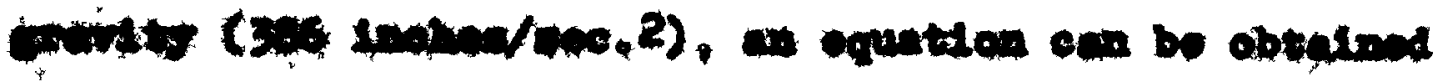

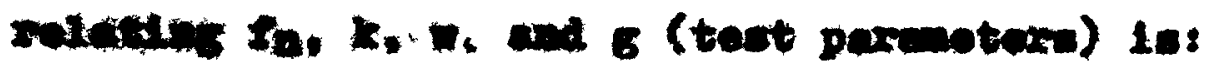

$$
x=\frac{\pi^{2} \sin ^{2}}{\mathrm{c}}
$$

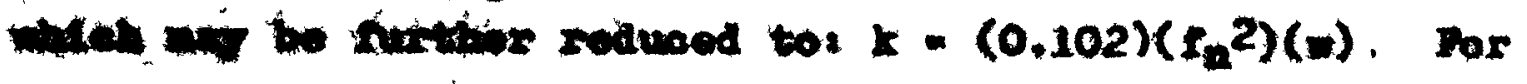

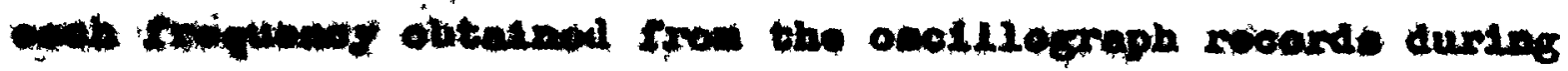

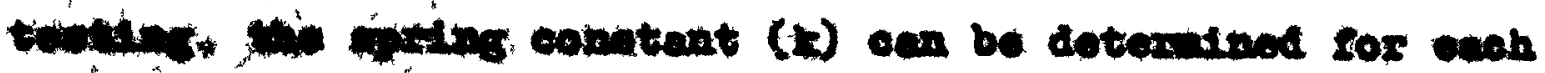
under tomation.

\section{Diming}

s/ll 2008-38-1, firet wight condition, $k$ is round to bea

$$
\begin{aligned}
k & =(0.102)\left(x_{n}^{2}\right)(w) \\
& =(0.102)\left(24.6^{2}\right)(61.375) \\
& =(0.102)(605.16)(61.375)-37881 \text { b. . } .1 \text { noh. }
\end{aligned}
$$





\section{$\therefore$ Limat}

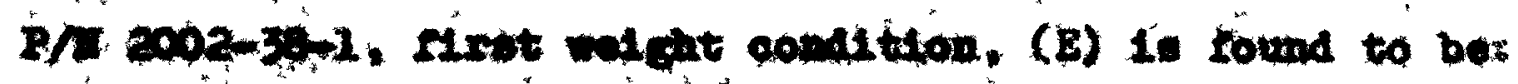

$$
\begin{aligned}
& =\frac{(0.102)\left(\sin ^{2}\right)(-12)}{1} \\
& =(0.192)(2,6) 2(102,25) \\
& \text { - 15s9 1be./1n. } 2
\end{aligned}
$$

wh sont of the ralues of (E) , sos all amples, are inoluded

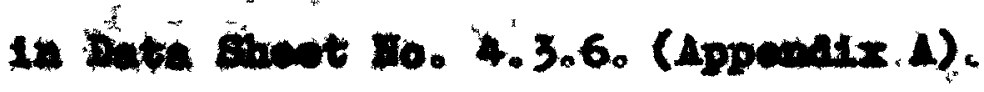

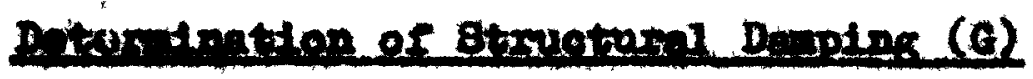

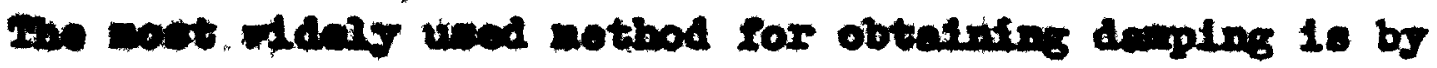
the los doosment procose. With this prooeses. the oroten is

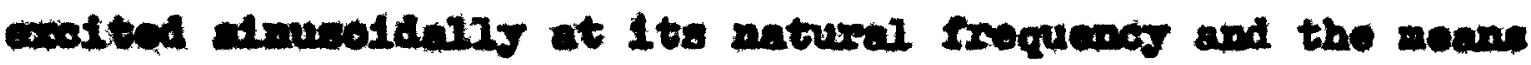

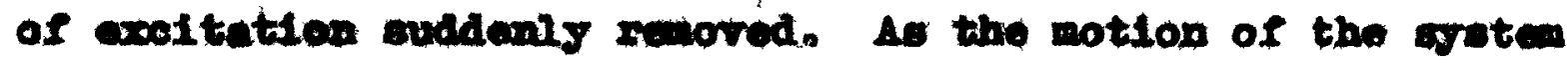
doowe, the ontpat of aceoleromoter wounted on the structure

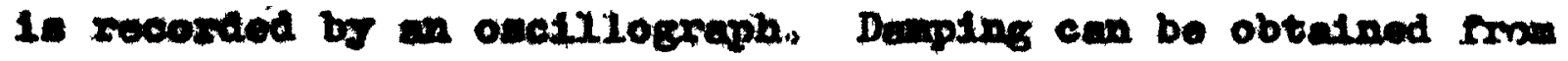
thin trade uatug the equation:

$$
0-\frac{1}{\pi} \operatorname{Ir}\left(A_{0} / A_{n}\right)
$$

whare to to the trece amplitude at the start of readable decay,

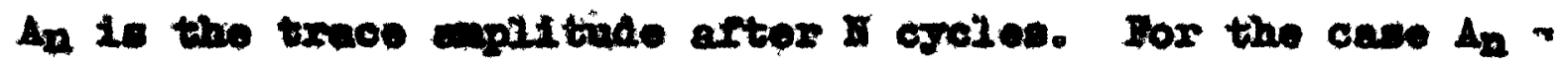
$0.5 \mathrm{H}_{0}$, the abore equation can be reduod to atnplex Iorm: 


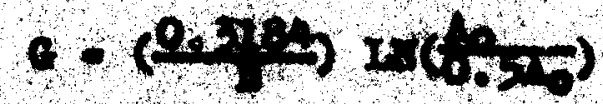

$$
\begin{aligned}
& \text { - }\left(^{n+364}\right. \text { In(2) }
\end{aligned}
$$

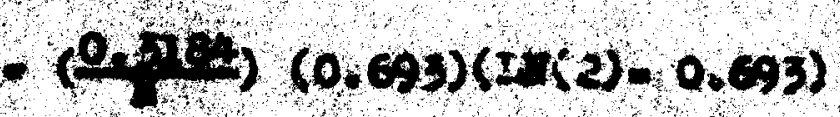

$$
\begin{aligned}
& 0-0.280 .4 \\
& \text { 1.ming P// 2002-30-1 }
\end{aligned}
$$

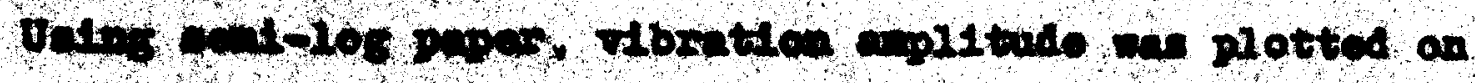

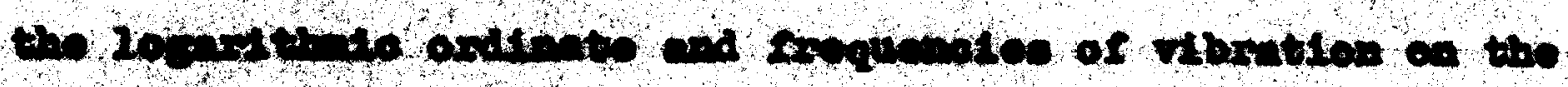

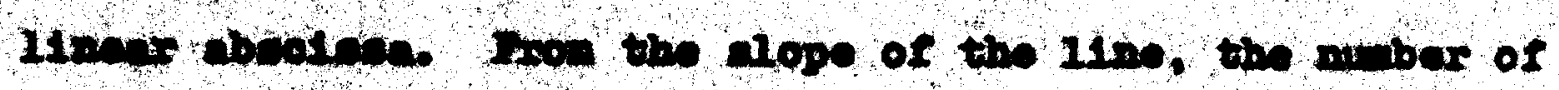

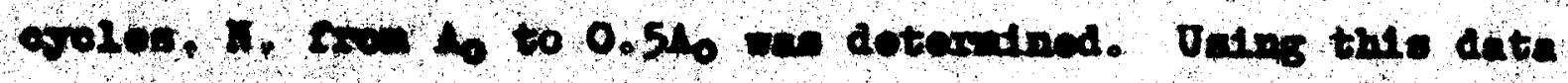
and the quateres

$$
0-0.2206 / x \text {. }
$$

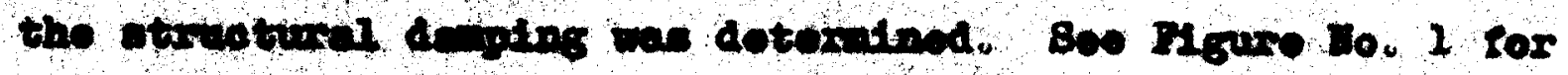
a plot of aplitude ne. rooquanog (daping). the raluee of (0) tor 11 anplos are included in Date shoot Ho. 4.3.6, (Apponder L). 


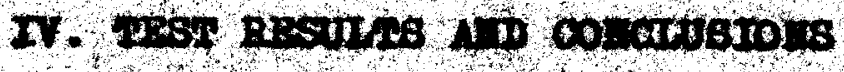

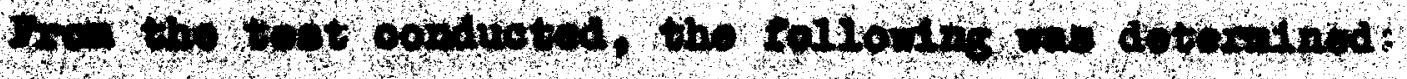

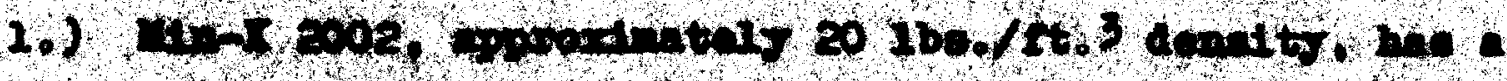

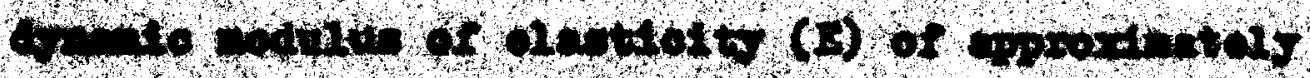

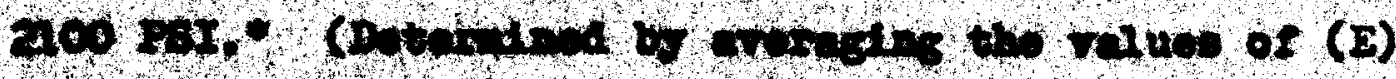

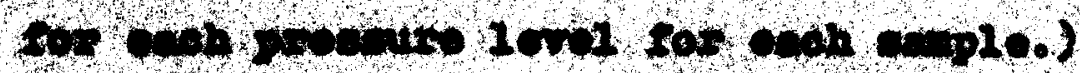

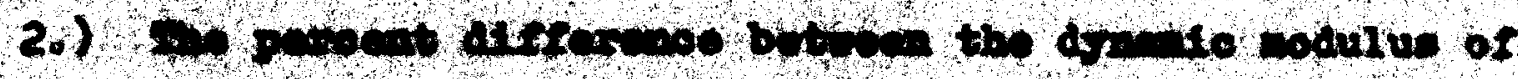

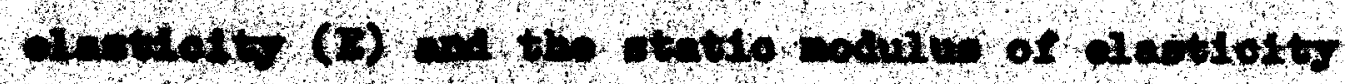

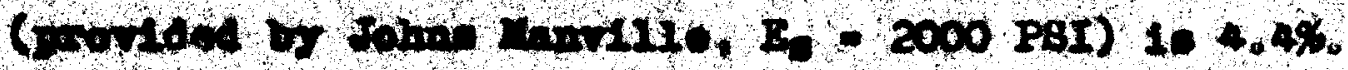

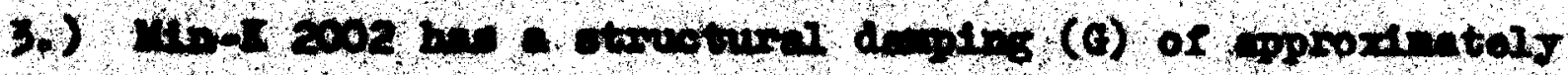

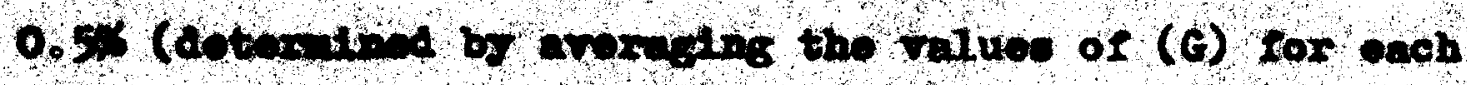

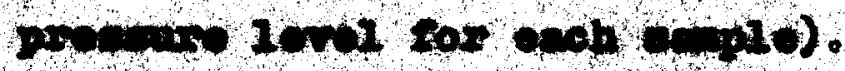

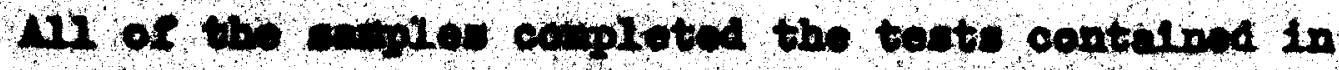
Appandix $\mathrm{B}$ althont faliuro. Stroe thore nere no falluros.

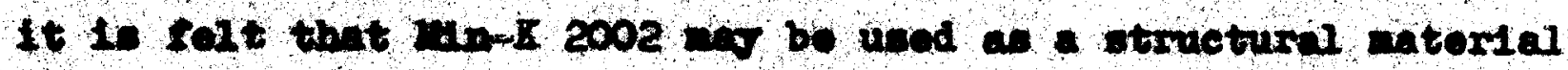
Athin the lint to abow in the roport.

As the plight 1 mols lnorgased, the talue of (D) al wo

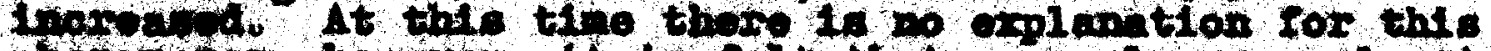

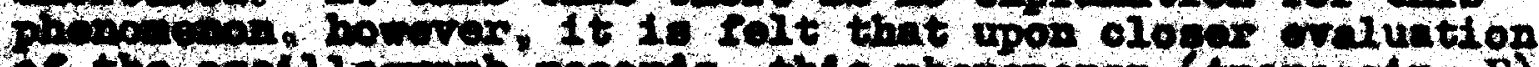
of the orellilograph records, this phemonemon (troreating E) 20 bo empiatnod. 


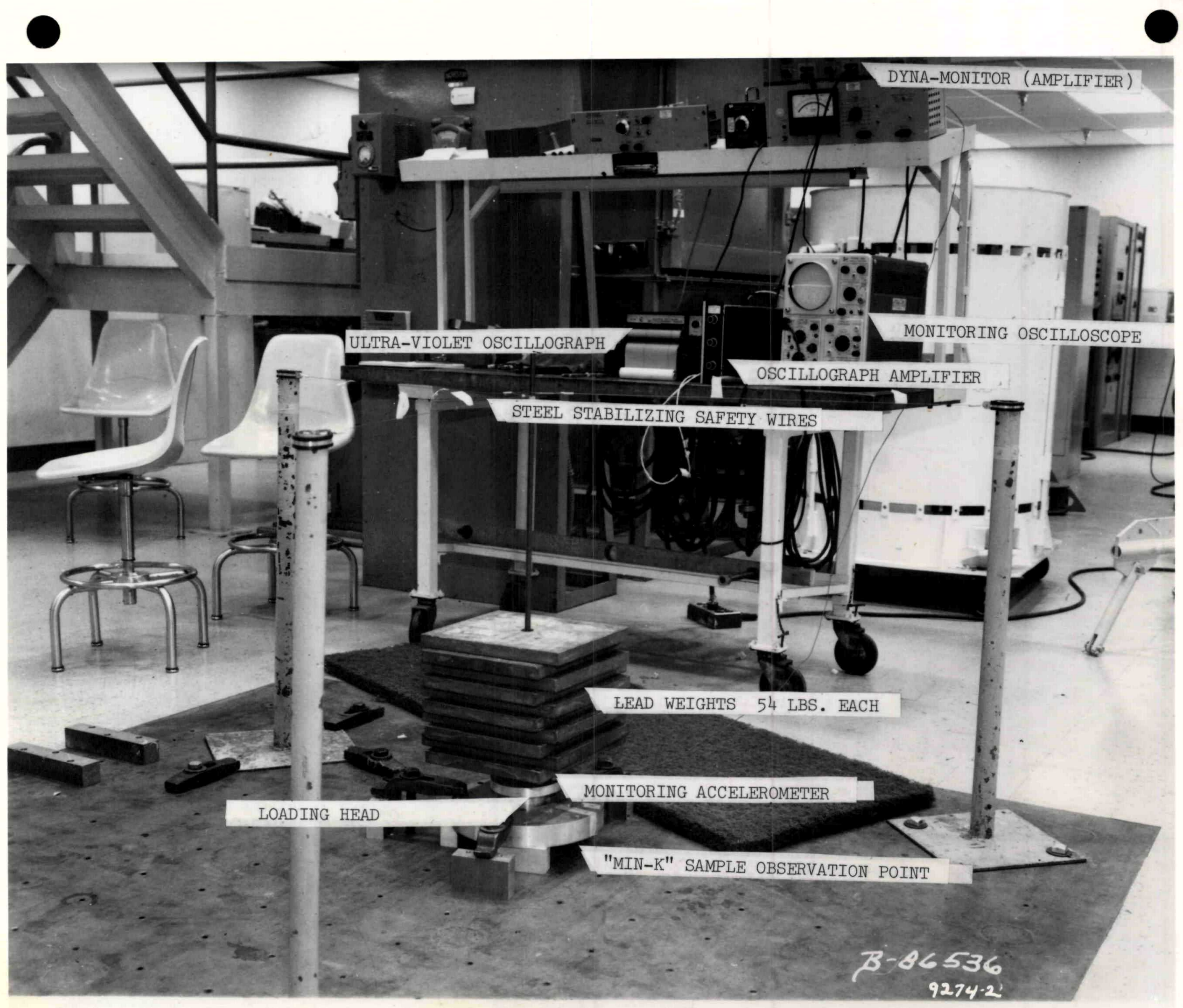

FIGURE NO. 2 


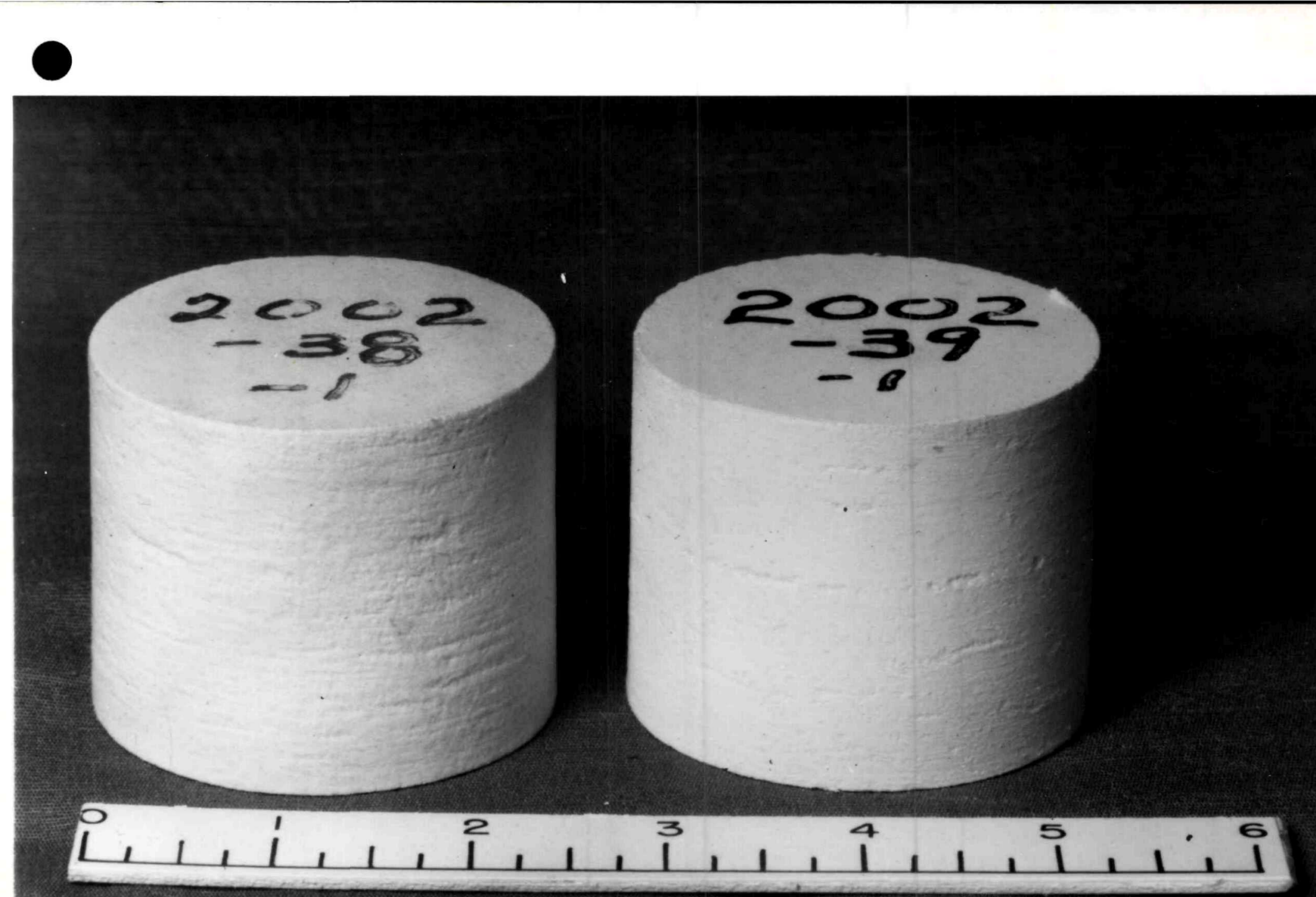




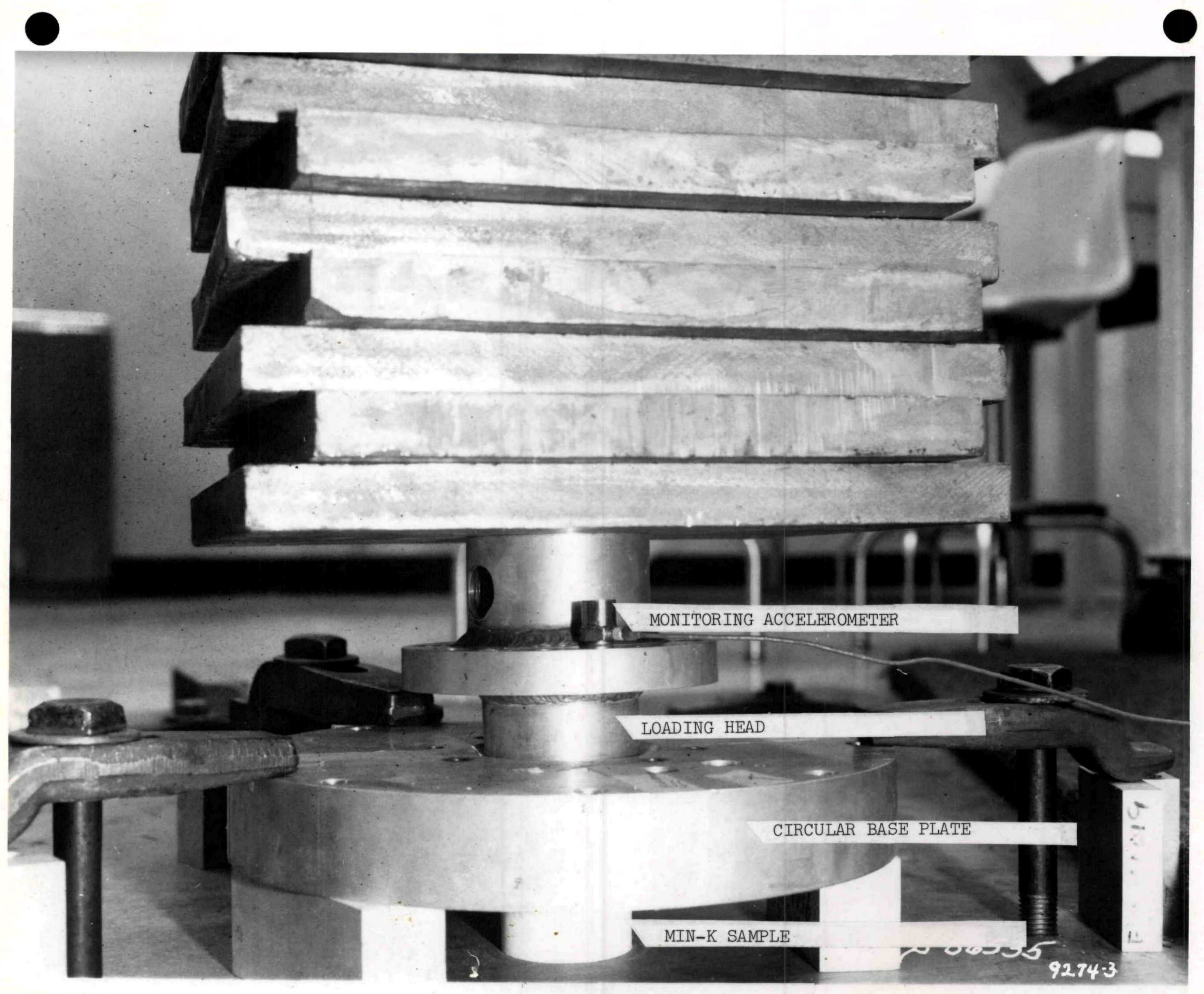

FIGURE NO. 4

CLOSE-UP OF TEST ARRANGEMENT 


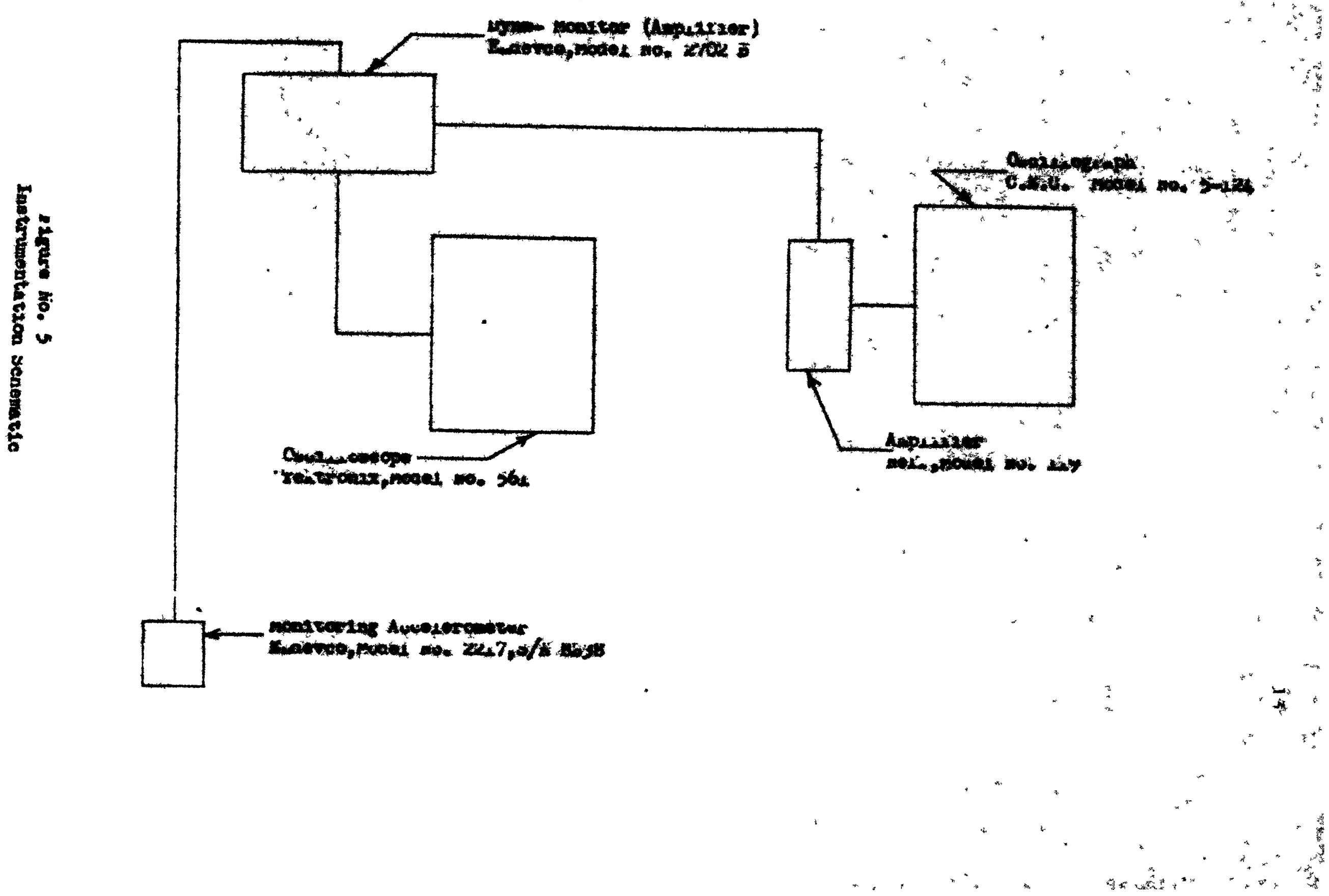




\begin{tabular}{|c|c|c|c|c|c|c|}
\hline 8pecimen Ho. & $2002-32-2$ & $2002-38-2$ & $2002-38-3$ & $2002-39-1$ & $2002-39-2$ & $2002-39-3$ \\
\hline Worght Condition & \multicolumn{6}{|c|}{$\mathbf{k}$} \\
\hline 2 & 3708 & 1008 & 4564 & 4838 & 4463 & 4167 \\
\hline 2 & 4002 & 1069 & 4634 & 4871 & 4402 & 4222 \\
\hline 3 & 4097 & 4204 & 4703 & 4838 & 4478 & 4204 \\
\hline 4 & 4282 & 4344 & 4929 & 5132 & 4599 & $440 ?$ \\
\hline 5 & 4576 & 4504 & 5094 & 5247 & 4722 & 4576 \\
\hline 6 & 4886 & 4644 & 5301 & 5472 & 4967 & 4724 \\
\hline 7 & 5122 & 4944 & 5487 & 5581 & 5222 & 4944 \\
\hline 8 & 5432 & 5140 & 5732 & 5937 & 5532 & 5236 \\
\hline 9 & $5 m 0$ & 5557 & 5879 & 6322 & $3 m 0$ & 5663 \\
\hline 10 & 6047 & 6047 & 6164 & 6526 & 6047 & 5932 \\
\hline Average & 4800 & 4748 & 5249 & 5474 & 5010 & $480 ?$ \\
\hline
\end{tabular}




a $x+2 x$

\begin{tabular}{|c|c|c|c|c|c|c|c|c|c|}
\hline \multicolumn{3}{|c|}{ 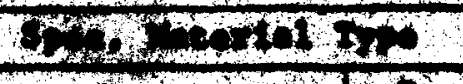 } & $B T, 1-\alpha$ & $\left.m n_{1}\right)=\alpha$ & mTN-K & \multicolumn{2}{|c|}{$n T_{1}-\mathrm{k}$} & 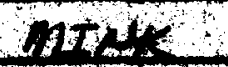 & $m T \Delta-k$ \\
\hline \multirow{2}{*}{\multicolumn{2}{|c|}{ 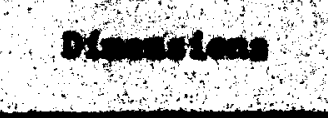 }} & D & 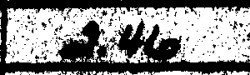 & $x / s$ & 2,42 & \multicolumn{2}{|c|}{2,10} & $2+2$ & $2+w_{2}$ \\
\hline & & $\mathbf{z}$ & 20 & 20 & -20 & \multicolumn{2}{|c|}{20} & 0.0 & $2 \Omega$ \\
\hline \multicolumn{3}{|c|}{ 2. } & 423 & 4212 & 42 & \multicolumn{2}{|c|}{36} & 40 & $82=2$ \\
\hline \multirow{2}{*}{\multicolumn{3}{|c|}{ 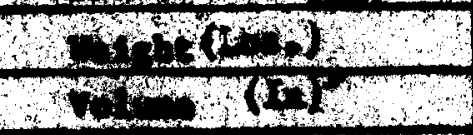 }} & .015 & .028 & 21113 & \multicolumn{2}{|c|}{1122} & nual & aras \\
\hline & & & 948 & 820 & 972 & \multicolumn{2}{|c|}{920} & 962 & $96 \%$ \\
\hline \multicolumn{3}{|c|}{ 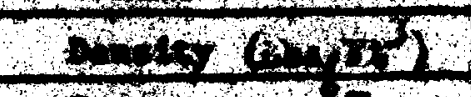 } & $2 \times 2$ & 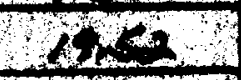 & 2969 & \multicolumn{2}{|c|}{00.41} & 1000 & $230 \%$ \\
\hline \multicolumn{3}{|c|}{$x+10000$} & 24 & $24 \%$ & 24 & \multicolumn{2}{|c|}{74} & 34 & 284 \\
\hline \multicolumn{3}{|c|}{ 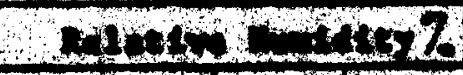 } & 30 & 30 & 30 & \multirow{2}{*}{\multicolumn{2}{|c|}{$\frac{30}{4635}$}} & 30 & 30 \\
\hline \multirow{12}{*}{ Erefe } & & 0 & 6137 & 2.02 & 62.375 & & & $403 \times 5$ & $61.3 \times 5$ \\
\hline & & 2 & 1285 & 6022 & 1243 & \multicolumn{2}{|c|}{12,79} & 1321 & 12.85 \\
\hline & 2 & $y$ & $215 \cdot 22$ & 119325 & us, $22^{2}$ & \multicolumn{2}{|c|}{115.825} & 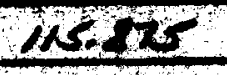 & 115.25 \\
\hline & & $P$ & 24.45 & 24.14 & 23.84 & \multicolumn{2}{|c|}{24.14} & oury & -24.4 \\
\hline & 3 & 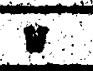 & 167325 & atax & 162375 & \multicolumn{2}{|c|}{167.375} & 10.325 & 164325 \\
\hline & & $F$ & 35.73 & 3629 & 3415 & \multicolumn{2}{|c|}{35,9} & 3521 & 35.73 \\
\hline & 4 & $y$ & 223,425 & $033,2.25$ & 223.425 & \multicolumn{2}{|c|}{223,625} & 223.625 & $203.4 \times 5$ \\
\hline & 5 & 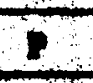 & $u+12$ & 46,52 & 46.01 & \multicolumn{2}{|c|}{4652} & 4459 & 4710 \\
\hline & 5 & $w$ & $27 x .125$ & $27 P .125$ & 278.125 & 278 & 205 & 274,25 & 279.125 \\
\hline & & 8 & 52.68 & 5794 & 57.23 & 52 & 44 & 5794 & 58.68 \\
\hline & 6 & 4 & $332.4 \times 5$ & 332.425 & 332.625 & 320 & 42 & 332.625 & $3,2.625$ \\
\hline & & 8 & 20,17 & 6230 & 68.44 & 69 & 30 & 69.30 & 20.17 \\
\hline & 1 & 1 & 246 & 243 & 27.0 & 27.8 & 27.0 & 347 & 25.8 \\
\hline & & 6 & $. \Delta a s-$ & .0055 & .0049 & Lenes & eenz & .003e & .0071 \\
\hline & & 8 & 1599 & 16,9 & 1978 & 2016 & Kon & 1259 & 1758 \\
\hline & & $E$ & 134 & 126 & 19.2 & 20.3 & 200 & 19.3 & 48,9 \\
\hline & 2 & 6 & .0040 & .0046 & .0047 & ooven & asen & .0049 & 00000 \\
\hline & & 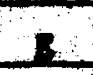 & 11889 & 1203 & 1907 & 2029 & 6912 & 1834 & 1781 \\
\hline & & $\varepsilon$ & 154 & 106 & 16.5 & 16,7 & $10 / 2$ & 16.1 & 15,6 \\
\hline trabules & 3 & 0 & 10049 & .0052 & 00049 & sare & Lone & .00412 & 0070 \\
\hline & & 5 & 1229 & $12-8$ & 19342 & 2007 & Lesa & $\angle 866$ & 1723 \\
\hline & & 2 & $-13,2$ & $-x^{2}-2=$ & +442 & $x=2$ & $4+4$ & -142 & 3.9 \\
\hline & & c & .0049 & 0.0047 & .0038 & toous & 60200 & 00052 & $.004 a$ \\
\hline & 8 & 2 & 1907 & 1810 & 2029 & $2 / 38$ & 2167 & 1911 & 1259 \\
\hline & & 2 & 12.7 & 12.6 & 13,4 & 13.6 & 13.8 & 129 & $\quad 2,7$ \\
\hline & 5 & $c$ & 10049 & .0042 & .0050 & Lou37 & .0004 & $100 \times 3$ & 2045 \\
\hline & & $E$ & 1931 & 1876 & 2097 & 2186 & 221 & 1967 & $1 \times 30$ \\
\hline & & $E$ & 12.0 & 11.7 & $12,5^{-}$ & 12.7 & 13.0 & 121 & $\angle 2.8$ \\
\hline & 5 & 6 & 0,048 & .0041 & .0043 & Gouns & .0044 & .0042 & .0059 \\
\hline & & 8 & $12 n 62$ & 1935 & 2182 & 2,280 & 2334 & 2004 & 1993 \\
\hline
\end{tabular}




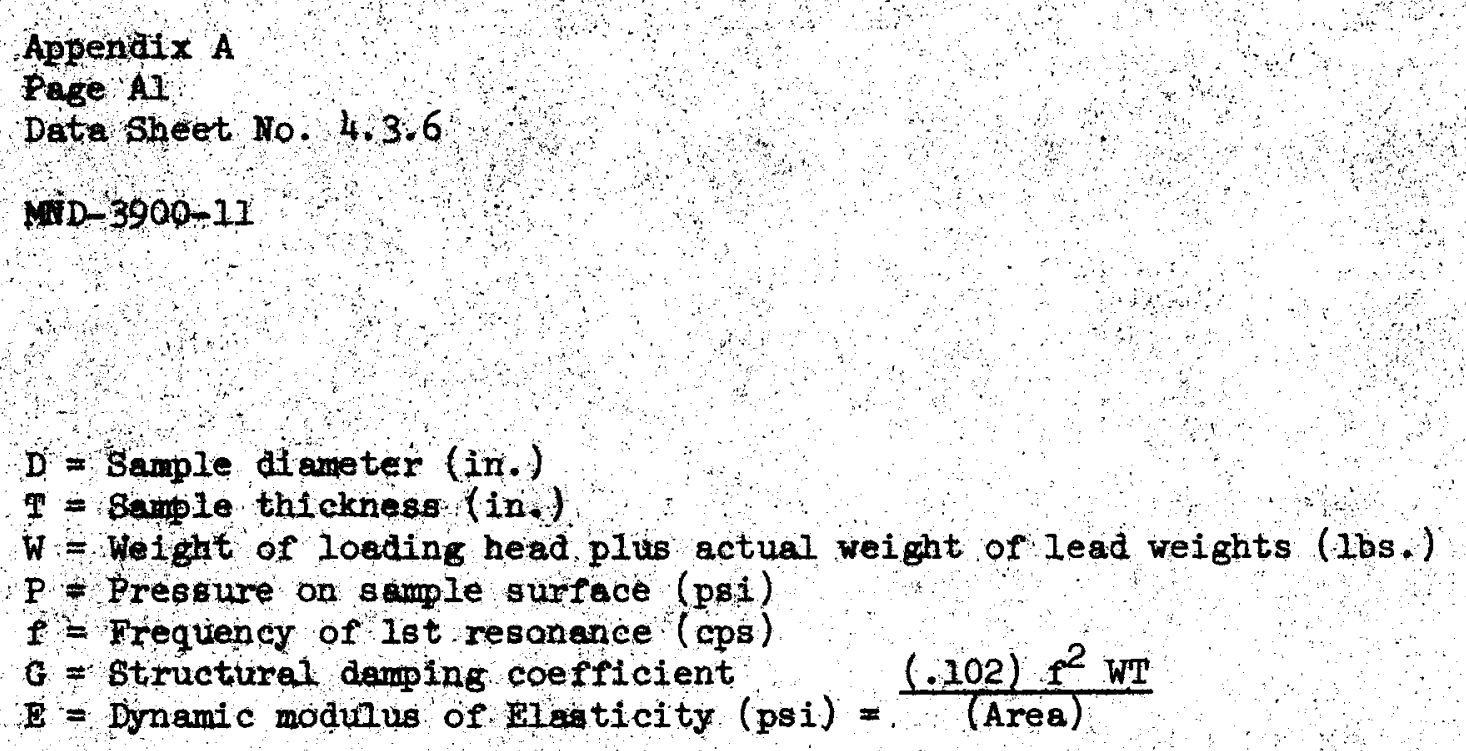




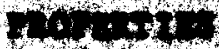

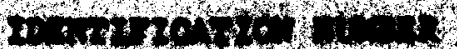

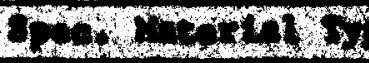

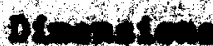

\section{+4 .}

$20+x+2(2 x-3, y$

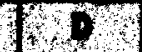

$\mathrm{C}^{2}$

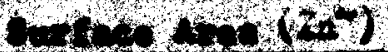

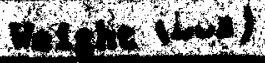

$\left.\ln (5)(w 0,1)^{3}\right)$

$3+2+1+2$

$310 x^{2}, 142 \%$ $420,(x)$

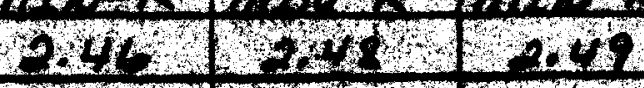

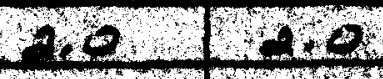

$474, \quad 40$

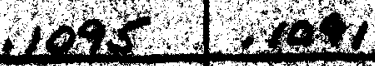

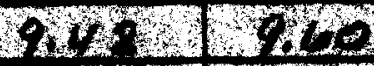

$\Delta L 2,+2,+2$

$77^{2}$

80

24

30

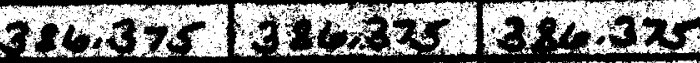

$2+\mathrm{s}^{2}$

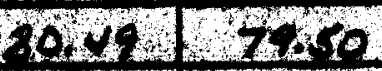

440100 . 440125

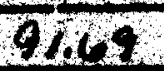

90.51

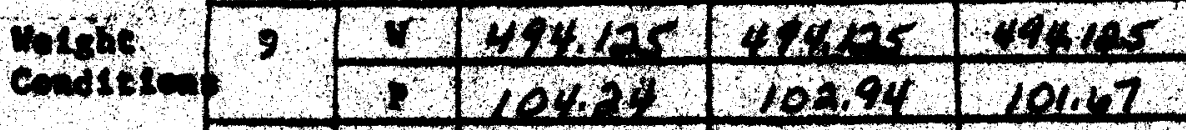

4

2. 104tal

n. $x+2 t+2$ $1,12,12 \mu$
$548 x t 5$

$11 \times 19$
$5,4,126$

112,2
Ho

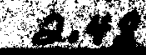
tost

$+2$

से,

$13+32$

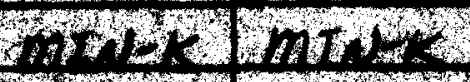

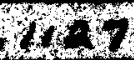

$\mathrm{SWH}^{2}$

$8 x^{2}$

30

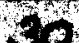

7. $20 \mathrm{~L}$

Q 20

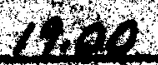

14.

30

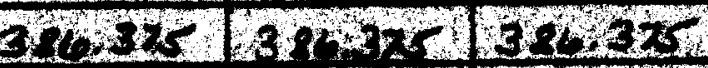

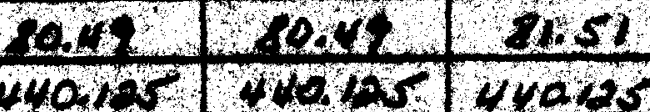

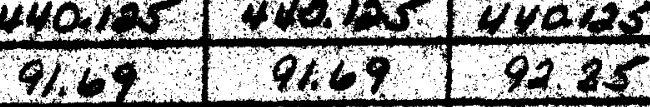

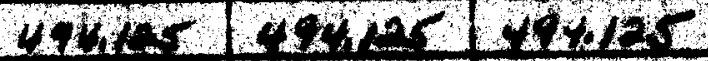
$10 \times 24$ $1069,1042 x$

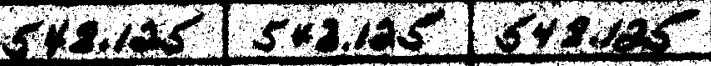
11412 11412 1,54

8

3

45

$20 \mathrm{C}$

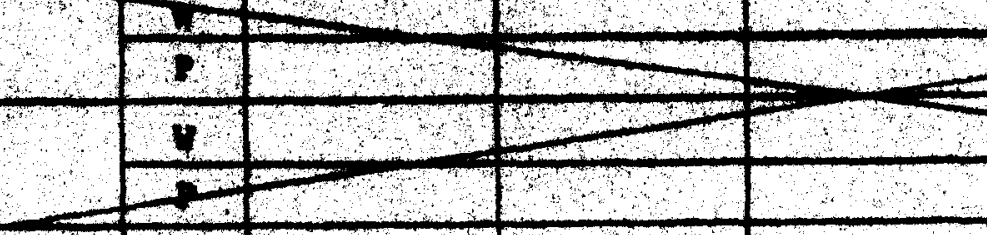

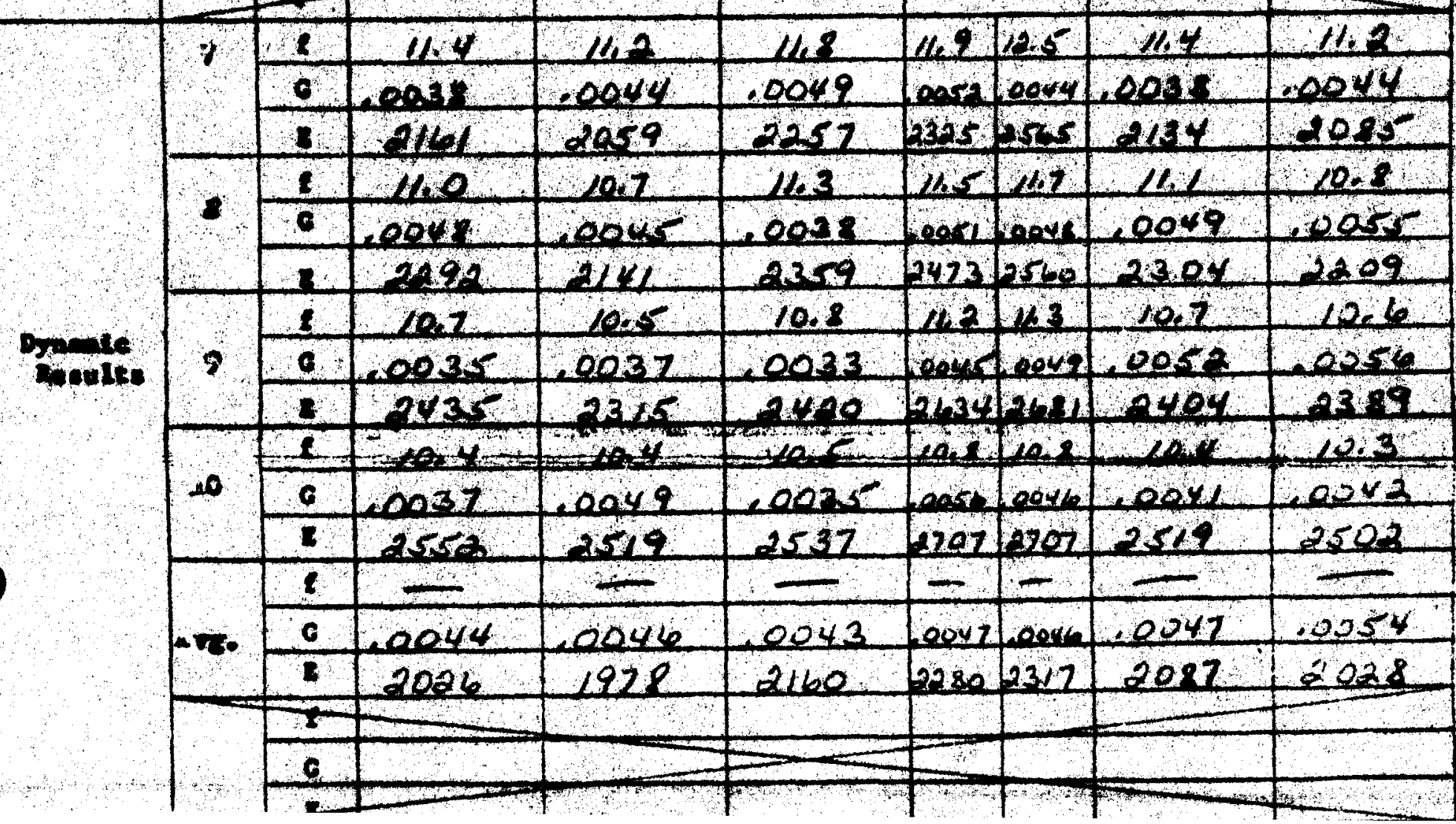




DYHAMIC PROPERTIRS

TEST PROCEDURE

IASULATION DEVELOPLEWT PROGRAM

MID-3900-7

30 December 1966

/s/ W. M. Griffin

W. M. Oriffin

Approved: $\frac{/ \mathrm{s} / \text { W. H. Lambert }}{\text { W. H. Inmbert. }}$

/s/ D. B. O'Brien

Approved: $\frac{\text { D. B. O'Brien }}{\text { O. }}$ 
TABLE OF COMHESTS

Paxe

1.0 objective...................... 1

2.0 scope ........................... 1

2.1 General Ilotes ................, 2

2.2 Applicable Documents . . . . . . . . . . 2

3.0 Drnamic Properties Tests ............. 3

3.1 Description of Test Semplas . . . . . . . . . 3

3.2 Recording System . . . . . . . . . . . 3

3.3 Teat Procedure . . . . . . . . . . . . . 3

Illutratioes ...................... 687

Dental shaent. . . . . . . . . . . . . . . . B 


\subsection{OBJECIIV:}

The pupoise of tals test is to determine the dynanic modulus of elastiglty and the etructurel dedping of insulation material. Deta

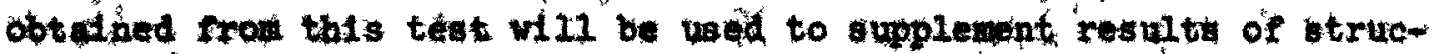

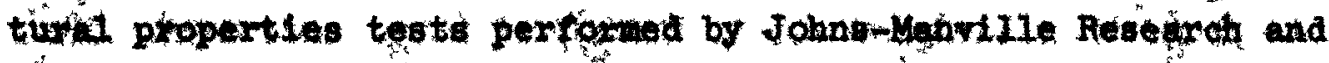
Fingibeering center in whell static modulus of elastielty. yleld stress, Hadilire stross, and logd relaxation of the material will be performed in

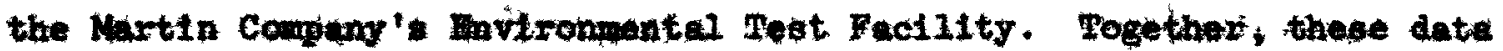
will provide the basic information necessary for analysis and désign of applieations in which the material is subject to the influence of external forces.

\subsection{SOOPE}

Bath aterial will be subjected to transient excitation teats to determate the dramic modulus of elasticity (E) and the structural damping coefficient (G) at room temperature. Samples will be cut from the and batich of parent waterial vith the test axis normal to the "Lavering pline" of the parent matertal.

Efrects of temperature, Iong-term, teliperature exposure, edge rostrafpt, wha consiatency of formulation (batches) are asaumed to have no effect on the structural properties of the material. These aseunptions, based on results from previous tests of a related material (MaD-3169-45), are subject to validation by the Jolms-Mariville static tests. If any of the above ilated assumptions are shown to be incorrect, It be necessary to perform additional tests. 


\section{2,1 General Notes}

\subsubsection{Woesurement Error}

The maximum allowable lnstrument error shall be as follows:

$$
\begin{aligned}
& \text { Vibration Amplitude } \\
& \text { Vibration Frequency } \\
& \text { Additional tolerances as specified }
\end{aligned}
$$

\subsubsection{Standard Conditions}

Unless otherrise specifled, the standard conditions

for conducting tests shall be as follows:

$$
\begin{array}{lc}
\text { Temperature } & 77 \pm 18^{\circ} \mathrm{F} \\
\text { Relative Humldty } & 90 \% \text { or } 1088 \\
\text { Barometric Pressure } & 10 \mathrm{cal} \text { ambient }
\end{array}
$$

2.1.3 Test Equipment and Instrumentation

Itam

Accelerometer

Dyna-lionit tor

Amplifter

Photo-0te1llograph

Galrancueter

Tent Fixtive:

Lead Kelghts
Manufacturer

Endeveo

Endevco

C.E.C.

C.E.C.

Martin-Baltimore

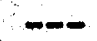

Mode1 2216

2702

$5-119-P 3-50 \quad 6$ months

$$
7-326
$$

Prior to test

88-3000514

Approx. $54268,11^{\prime \prime} \times 13^{\prime \prime} \times 1^{\prime \prime}$

- Existing Facizities Fabricated Under Another Program of a Similar Vature

\subsection{Applicable Documents}

Martin Document MMD-3169-45, January 1965, Structural

Evaluation of MIN-K 1301. 

3.3.3. Subject the specimen to a compresstan losd by adding one lead treloht to the top of the rixture (see Figure 10. 2) Determine the ectual vel ght on the specimen and record on lata sheet 3.3 .6 . calculate the total pressute on the specinen and record on date sheet 3.3 .8 ,

3.3.4 start the os alliograph to recoro the accelerometer output. Exclte the specinen by striking the lead wel ght near the center of gravity with a rubber hamer or equivalent object, continuously record the accelerometer output for a period of thme sufficlent to measure the rate of decay of the vibration amplitude.

3.3.5 Successively add lead velibhts and repeat the procedures of 3.3 .3 and 3.3 .4 for eqeh welght condition. This process shall be repeated until a total of six or more wel ghts are loaded on the assembly, as determined by the test engineer.

3.3.6 With the data from the osclilograph records, determine

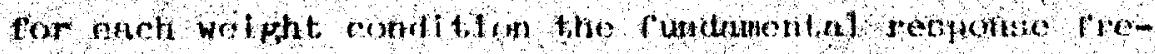
quency, dymame modulus of elasticity, and structural damping coefficlent as follows:

On semi-log paper, plot vibration amplitude on the logarithmic ordinate yers us number of cycles of vibration from a convenient starting point as the Inear abscissa, Determine from the slope of the Ine the number of cycles, $n$, for the amplitude to decrease to balf value. Calculate the struetural damping coefficient $G$ from the relationship $\frac{\alpha 2206}{n}$, and enter 1 ts value on data sheet 4.3 .6 . 


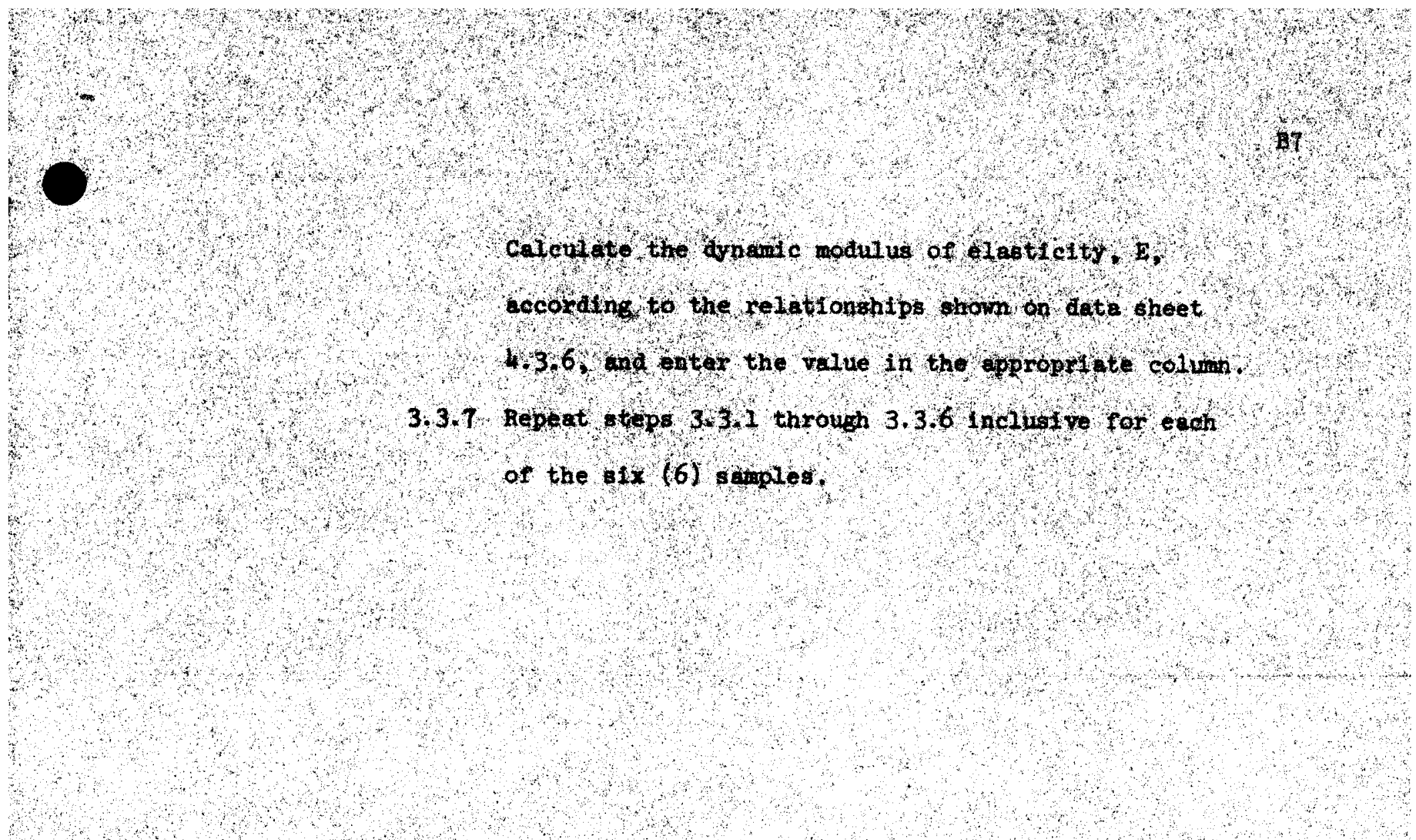




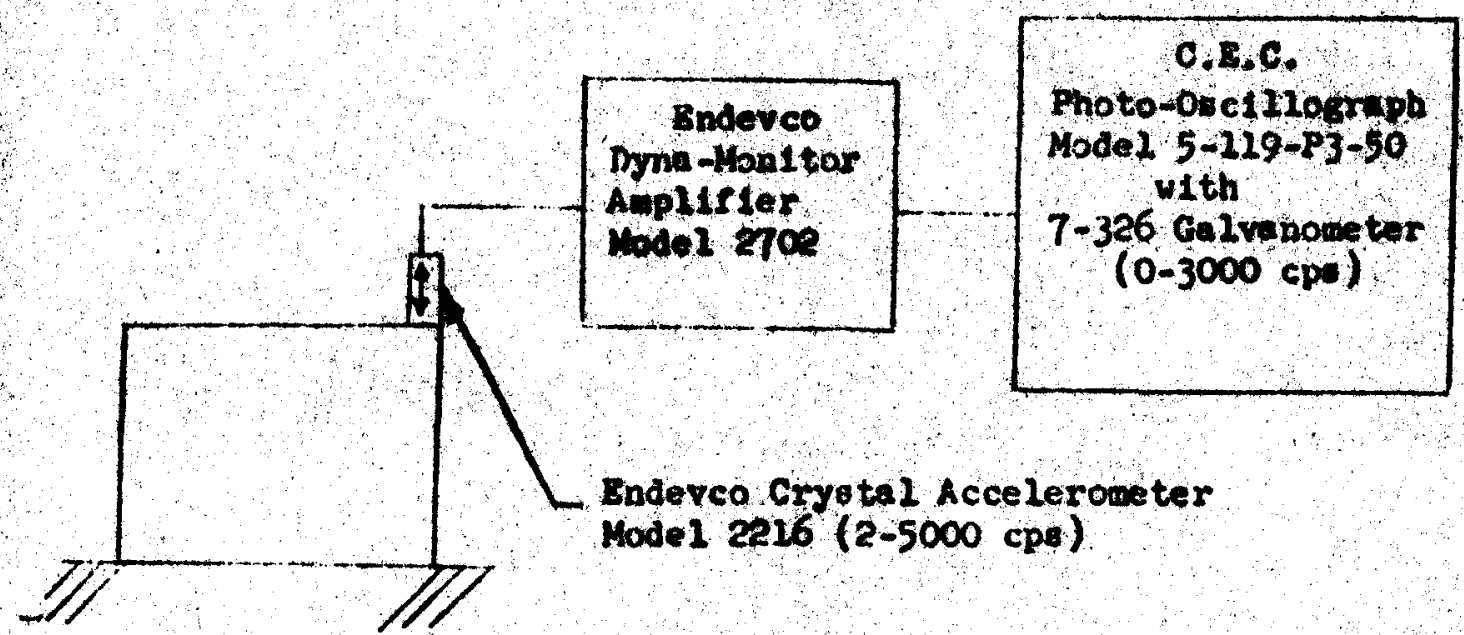

Teat 1xture

$88-3000514$

IIgure No. 1

Recnrding Schunatic 


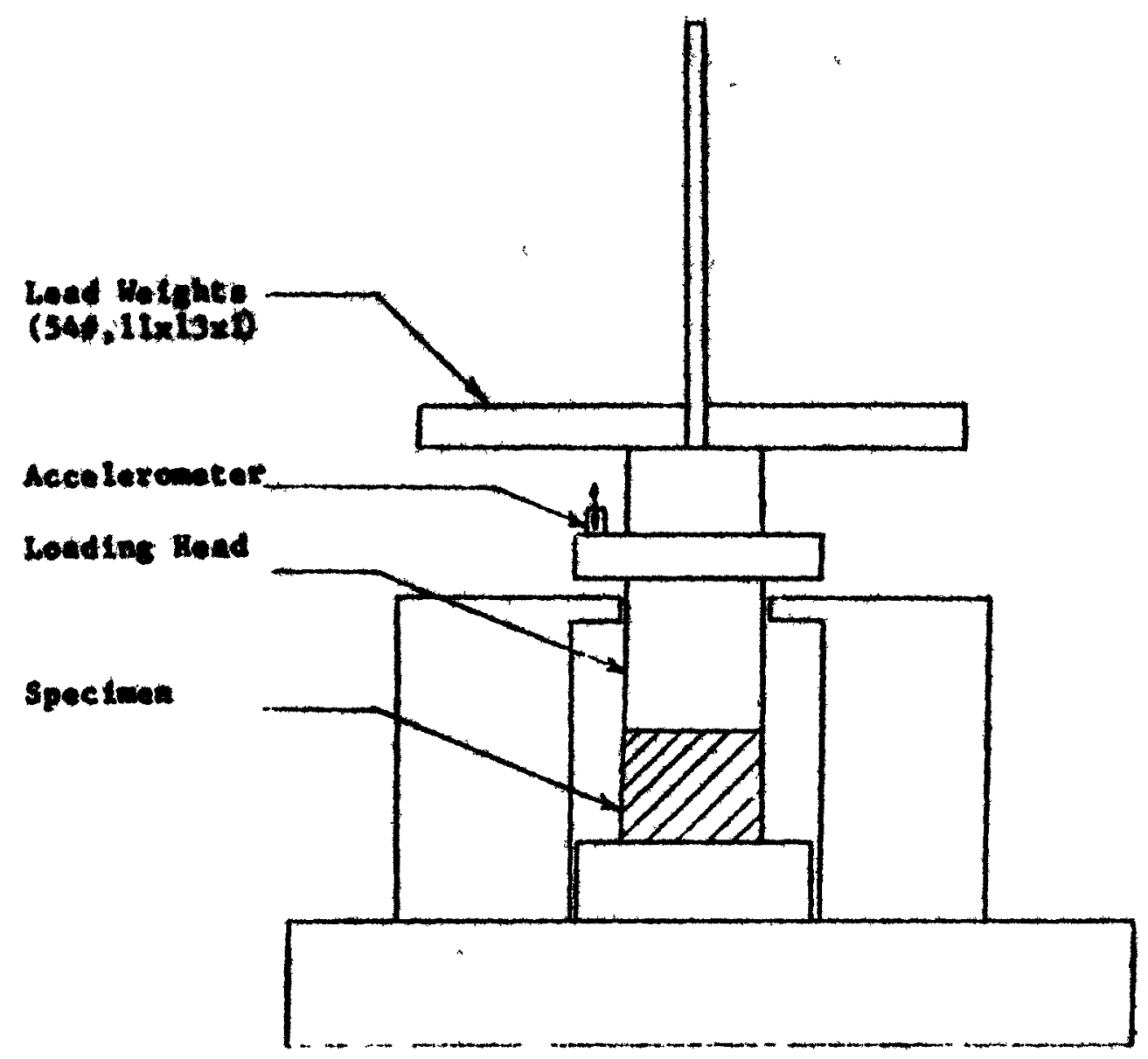

Figure No. 2

Baslc Test set-Up 


\section{Tibsuna moun Anton

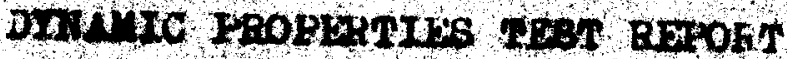 \\ $17 D-3000-1.2$ \\ 29 Herch 1967}

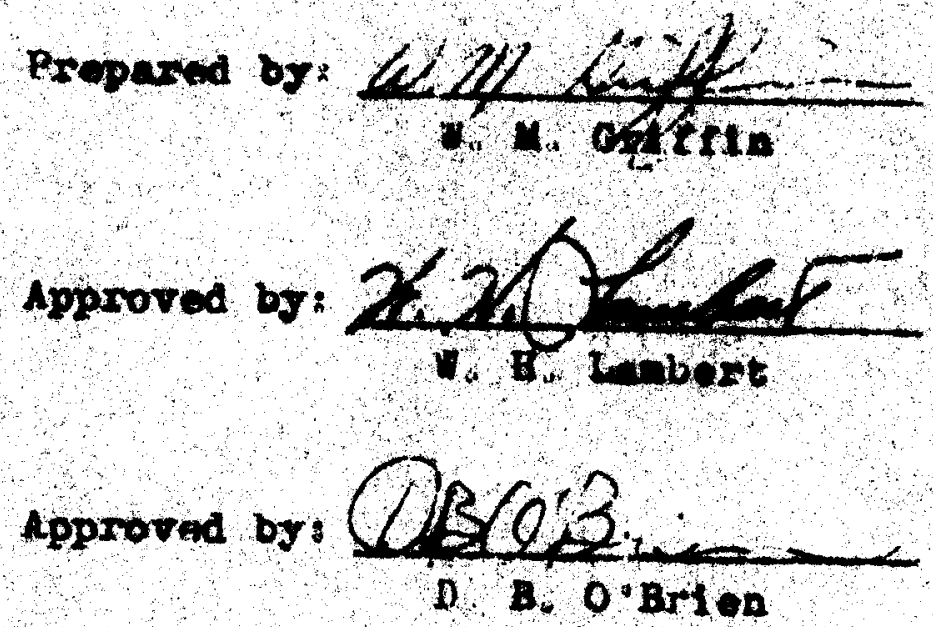

WARTM WRTEYTA COLPORAYTOA

RALTTUDKE, UARTIAND 21:03 
Wreti, wOWTE

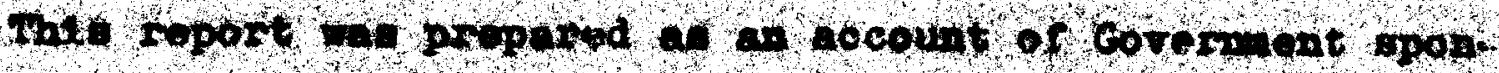

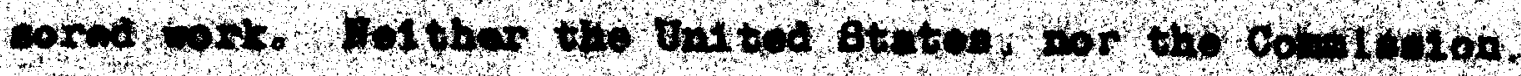

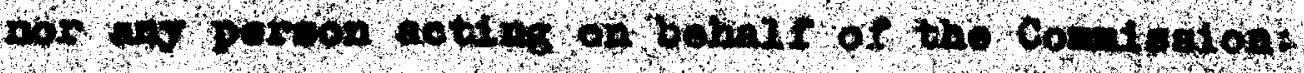

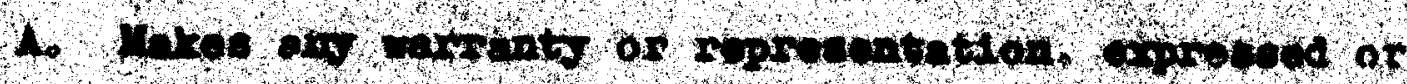

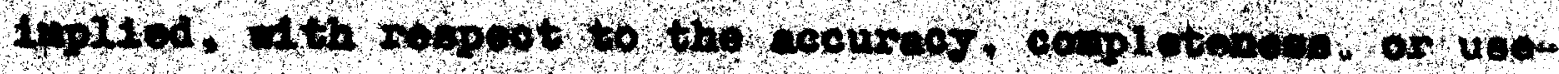

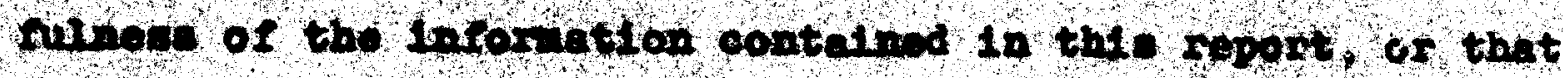

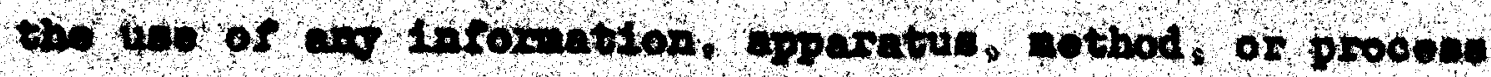

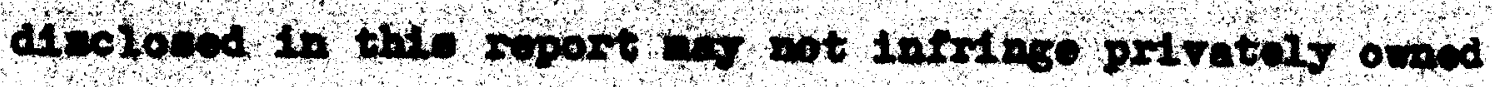
olghter or

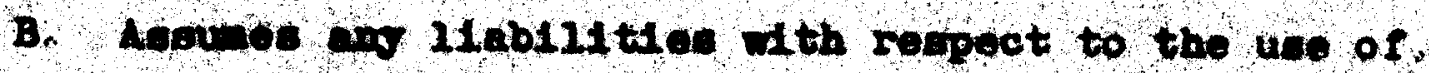

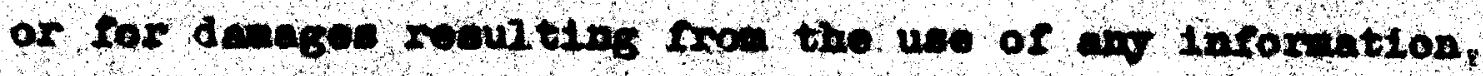
apprentua, eftod, or procose dibolosed in thits roport.

If uned In the above, "perpen acting on behalf of the

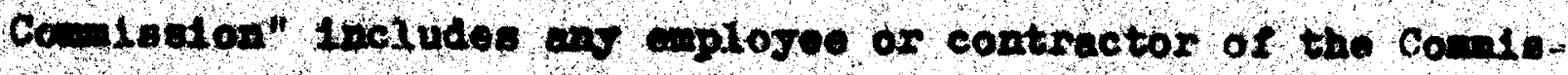
aten. or mplojee of uch contrector, to tho ontent that weh

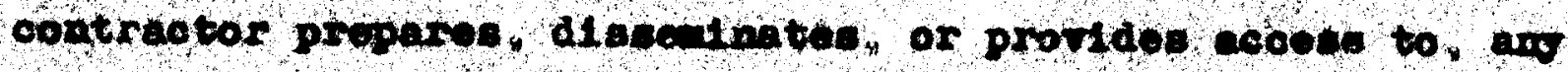
Imponation purguant to his explojeont or contract with the collidilon, or his exploynent with ouch contractor.

$$
\text { MTD }-3900-2
$$


sorang

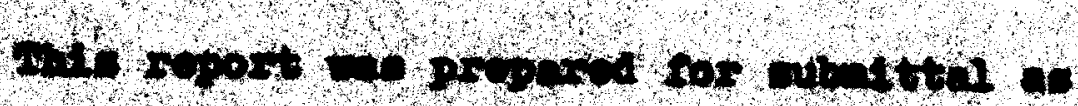

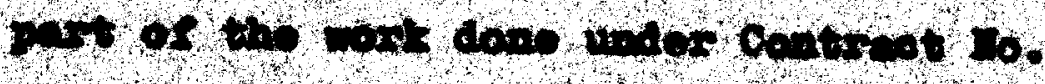

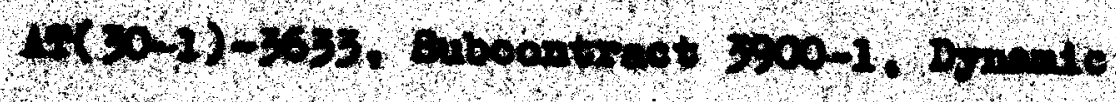

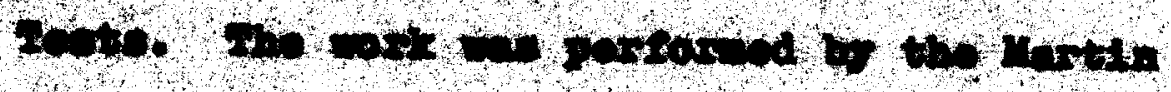

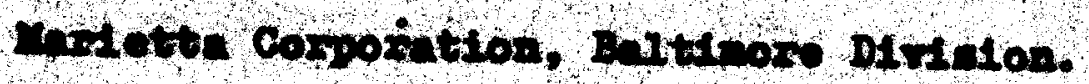




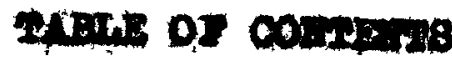

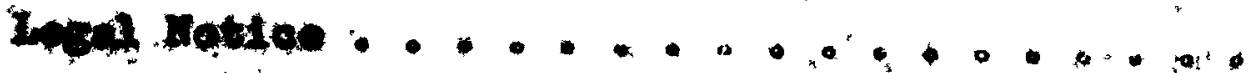

Praso.

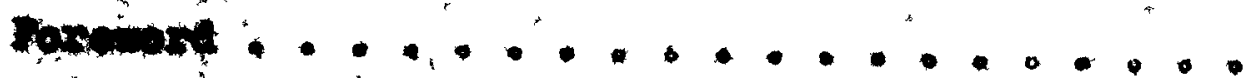

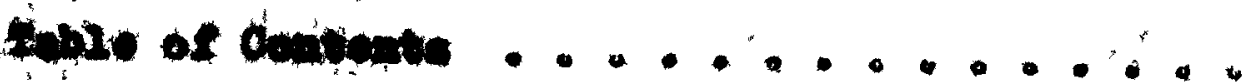

14

gingy

I. Dunpin . . . . .

17

$\boldsymbol{\nabla}$

2

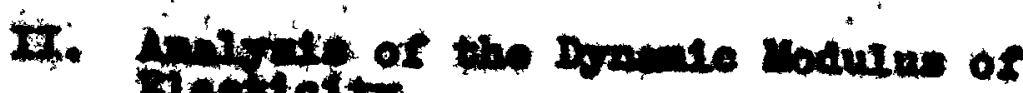

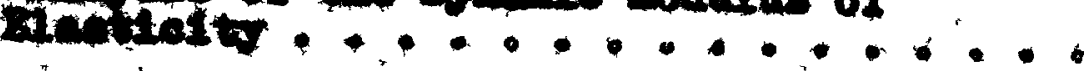

Iit. minateal Compatations

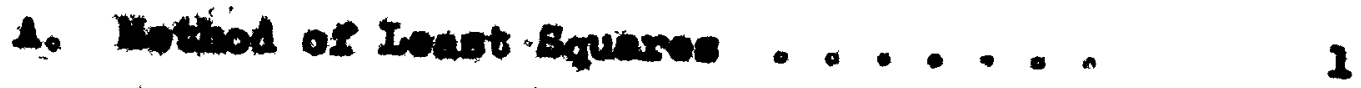

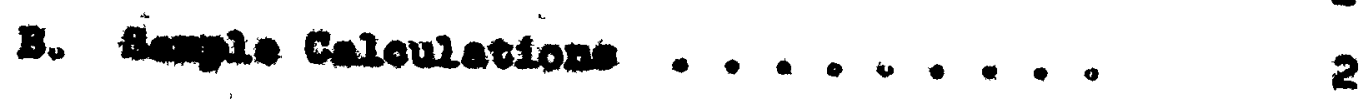

IV. Comaluation ................. 5

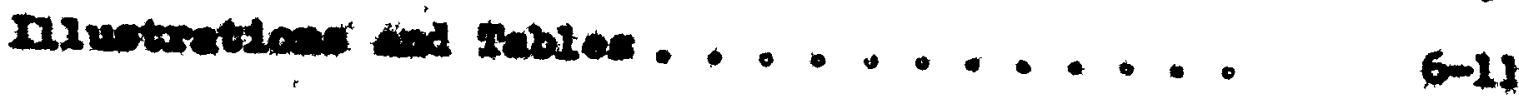


In Invertigntion was wade of apparant rarlation of (E)

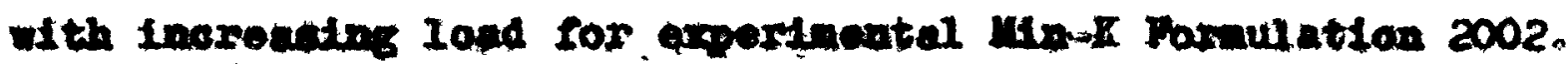
Tho omatllogruph treces of all aix (6) enpied were

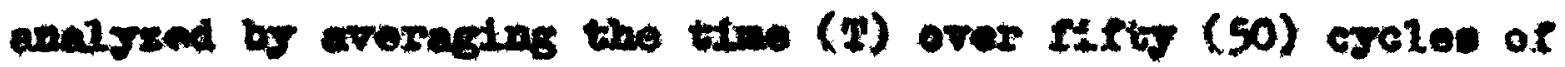
ribration. Comparing the orfelinel veluok of $(B)$ at th the romaxuspd ralues, theme in found to be approxtmataly a $0.4 \%$ alfrerence between the two. Whe porcent alfferonce 18 connidexed to be inatignifleant.

(E) VB. (PBI) was plotted on roctanguidur comordinate paper. The curve secas to be non-1loear in the region belor 35 PSI whoreas in the region above 35 PBI, the curve appears to be Iincar. The nethod of least squares was ued to deterine the stralght 1 ine whtch best flt the dato points. There 10 a defint te alope aseociated with the plot of (E) vo, (FSI), 


\section{Franam}

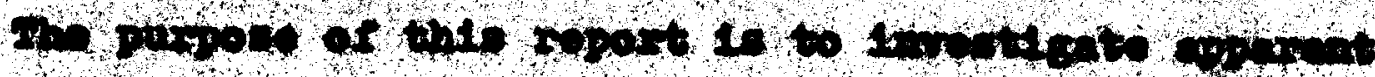

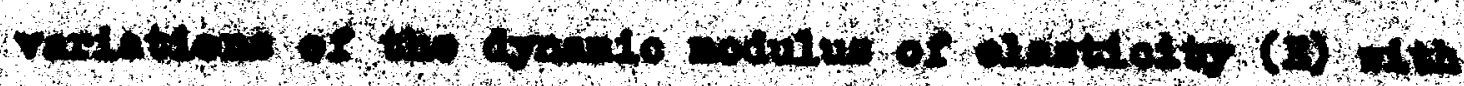

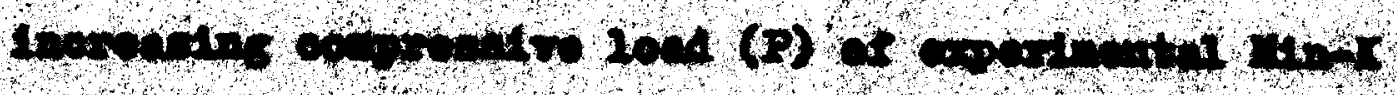

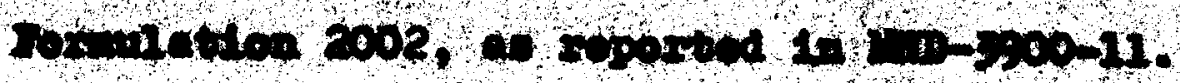

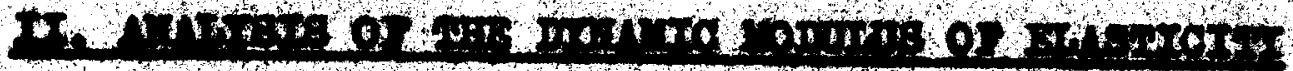

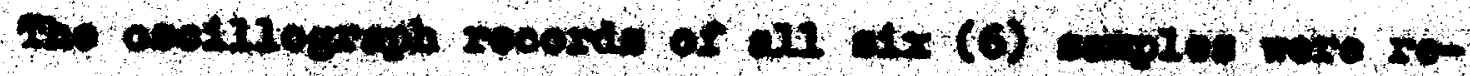

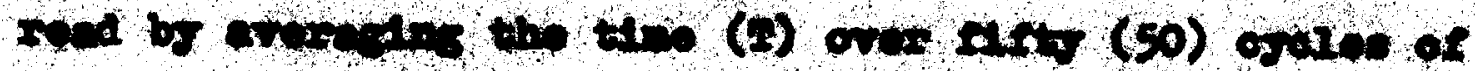

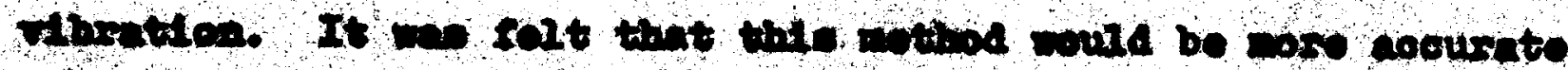

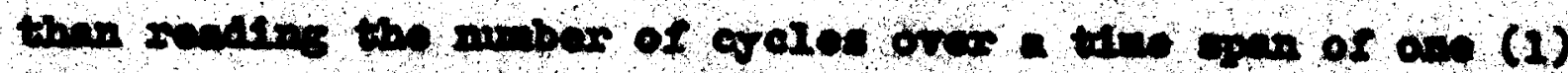

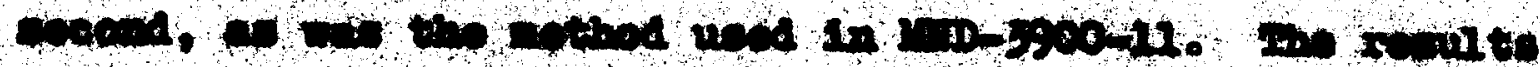

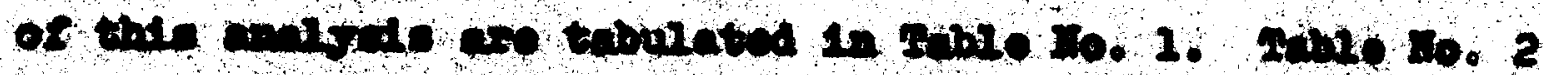

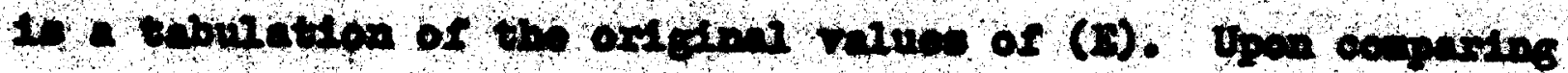

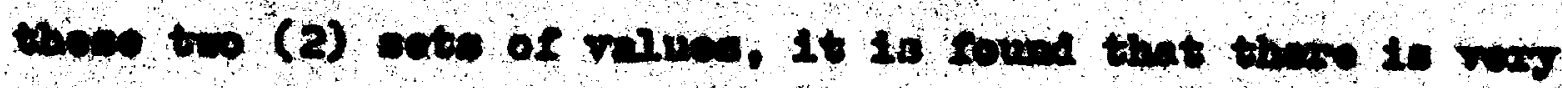

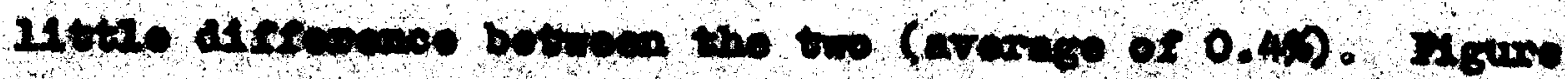

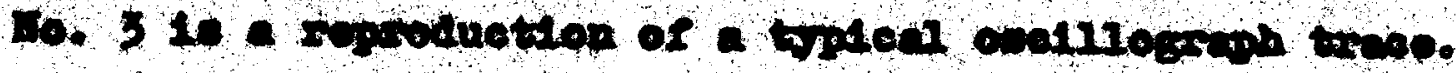

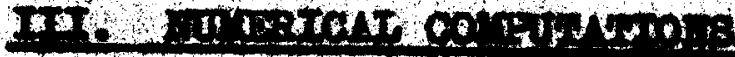

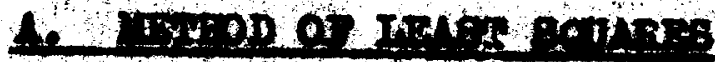

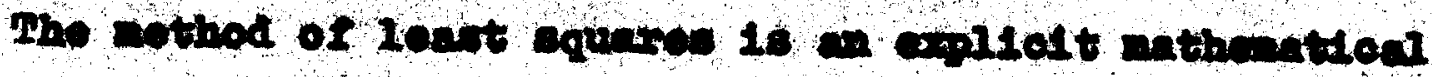

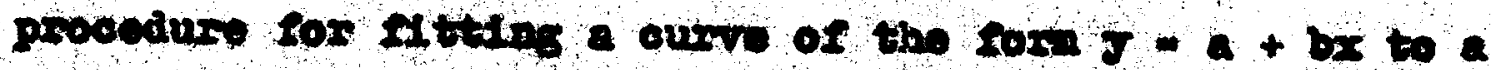
alten at of data. Jor a derivation of the nothod of least 


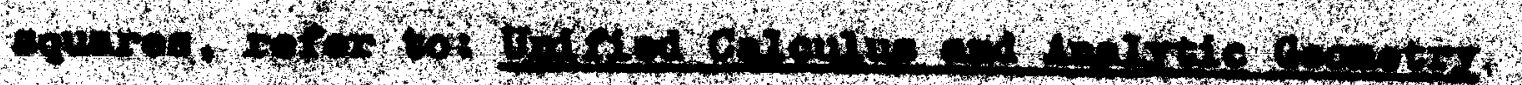

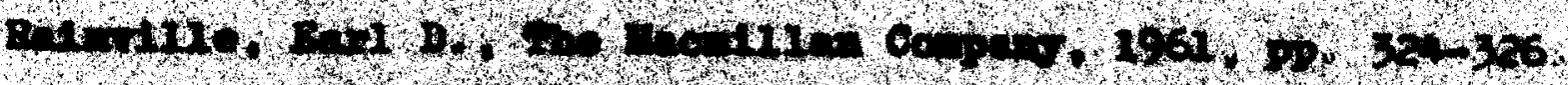

\section{4.trite orratroms}

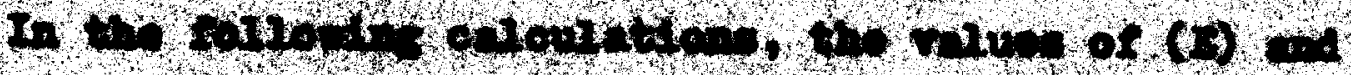

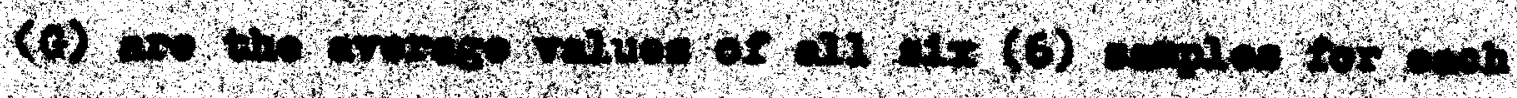

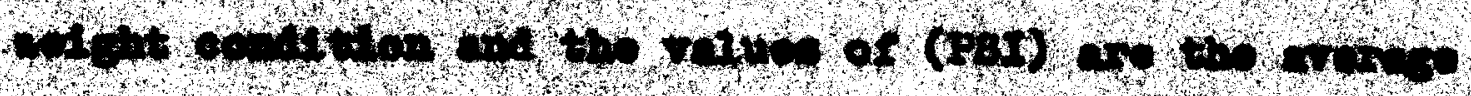

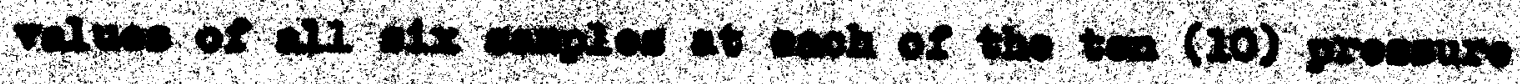

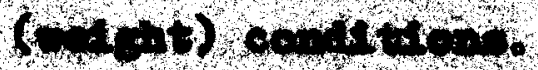

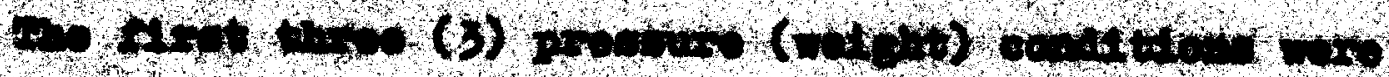

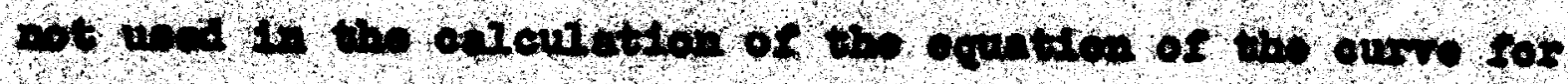

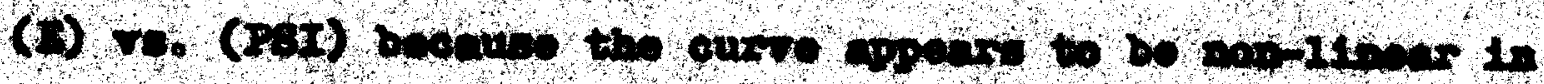

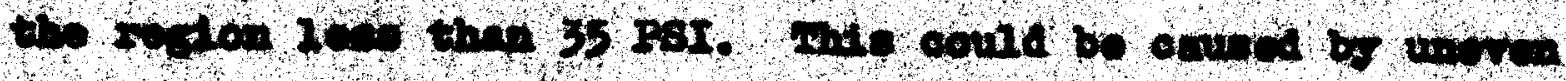

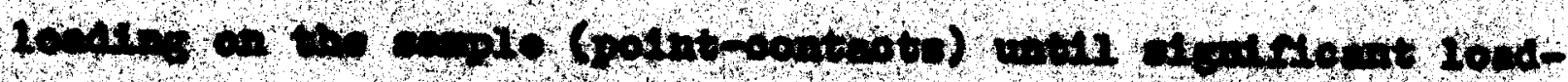

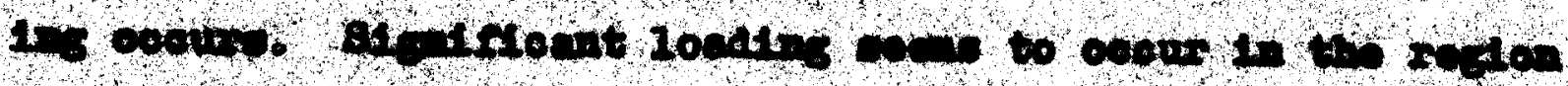

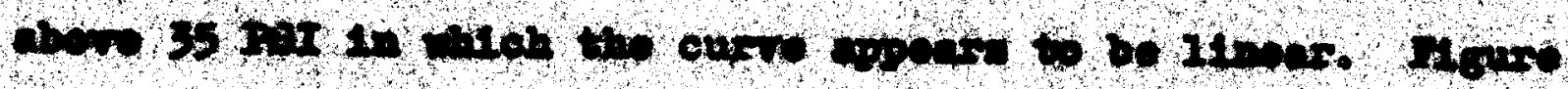

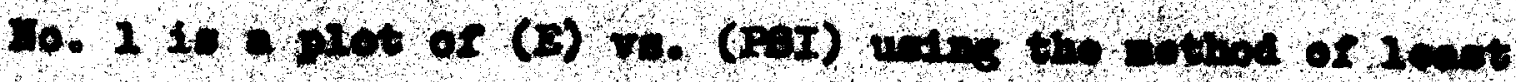

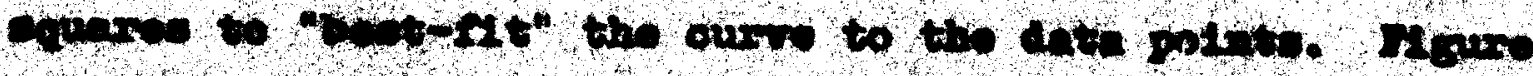

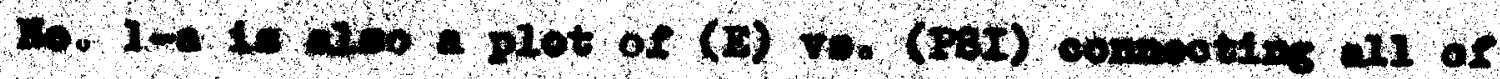
the data potres by a dooth aump.

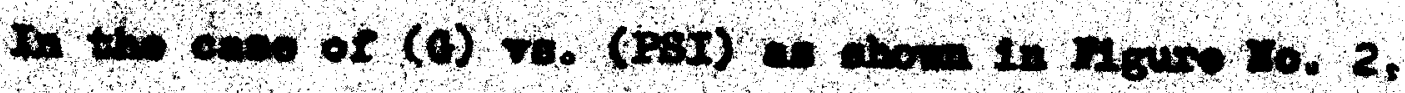

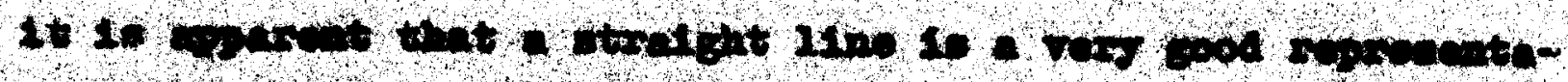

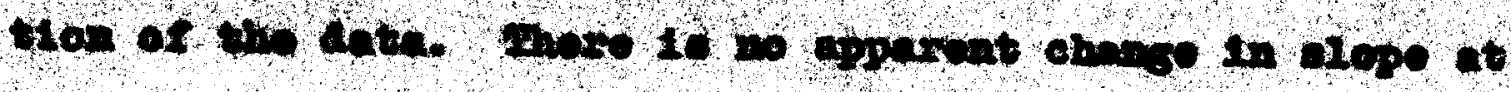

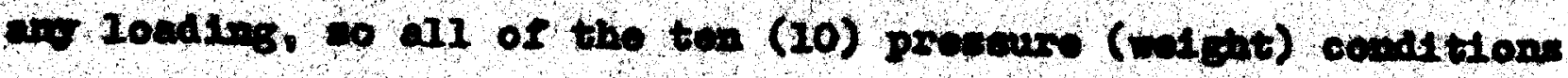
now ued in calculating the equation of the curre. 
B. Sample Calculations,

3.

Modvies of ELastricty K. PSI

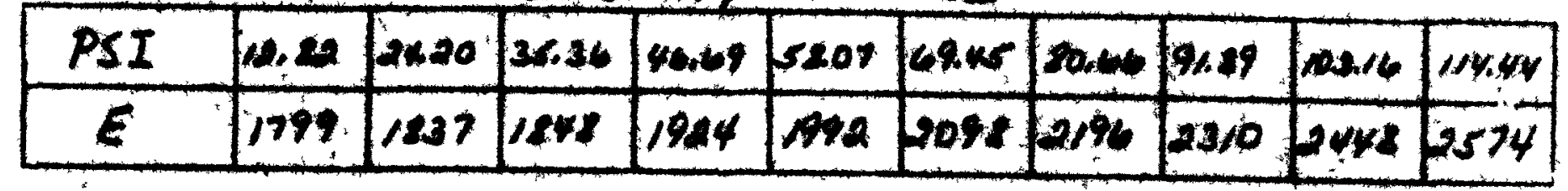

$$
\begin{aligned}
& \sum(P S I)=636.74-72.38=564.36 \quad \sum(742)^{2}=51064-2000.39=49063.68 \\
& \left.\sum(E)=21006-5424=15542 \quad \Sigma(20)(E)\right]=\text { meos } 75-132203=1287712 \\
& m a+b \sum(a x) \cdot \sum(\theta) \\
& \left.a \sum(p \leq T)+b \sum(p \leq)^{2}\right)^{2}=\sum[(p S I)(G)]
\end{aligned}
$$

By Substitutine The appeopriate Unues Into Twe Above Equation, Tre Foudowing Equation Is Oatawer:

$7 a+564 b=15542$ (Muktipey By 80.571428 )

$564 a+4900460=1287712$

$564 \mathrm{~g}+45442 \mathrm{H}+1252241$

-15 b4a $49064 b=1287712$

-3620 \& $=-35471$

$b=9.79$
$7 a+(564)(9.79)=15542$

$7 a+5522=15542$

$7 a=10020$

$a=1431$

Feom $y=a+b y$, The Equation of the Line Is Oatained,

$$
y=1431+9.79 x
$$

For $y=0 \rightarrow x=-146 \quad$ For $x=0-y=1431$ 
B. SAmpLe CALLULATIONS

Streuctuen Damene Ut PST

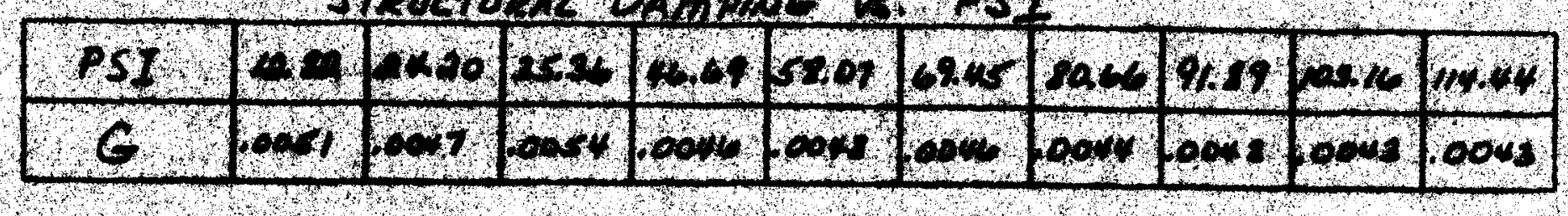

$$
\begin{aligned}
& \sum\left(P_{S}\right)=634.74 \\
& \Sigma(6)=0.017 \\
& M+b \Sigma(\sin )=\Sigma(6) \\
& a \Sigma(P S T)+b-\Sigma(P S I)^{2} \cdot \Sigma[(P S T)(G)]
\end{aligned}
$$$$
\sum(P Q T)^{2} \cdot 51064
$$$$
\sum[(P S I)(G)] \cdot 2.915
$$

By Sunstituting The Aapeoneiate Values Into The Above Equatou, THe FQMCOWING EQUATON IS OATANED:

$$
10 a+636.74 \text { W }=0.047 \text { (MuLTray By } 63.674 \text { ) }
$$

$63674 a+5106460=2.915$

$$
\begin{aligned}
& 636.74 \mathrm{C}+\text { vark4 } t=2,993 \\
& 024674 a \pm 51064 \text { b5 } 52.9 / 5 \\
& 10 a+(636.74)\left(-7.4 \times 10^{-6}\right)=0.047 \\
& 10 a-0.0047=0.047 \\
& 10 a=0.0517 \\
& y=-\left(7.6 \times 10^{-6}\right) \\
& a=\left(5.17 \times 0^{\circ}\right)
\end{aligned}
$$

FROM $y=a+b x$, THE EQUUATION OF THE LINE IS O OTANED,

$$
y=\left(5.17 \times 10^{-2}\right)-\left(7.4 / \times 10^{-6}\right) \psi
$$

For $y=0 \longrightarrow x=698$

For $x=0 \rightarrow y=0.00517$ 


\section{4. conimtistors}

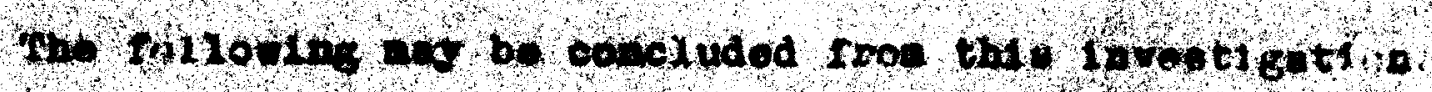

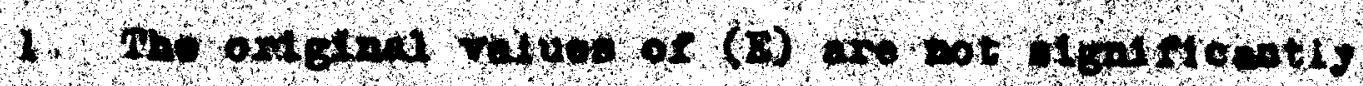

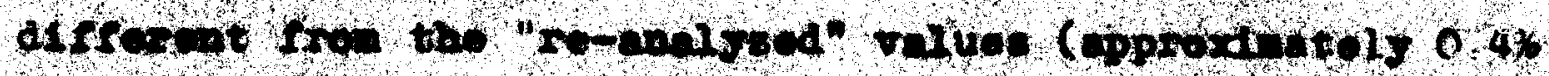

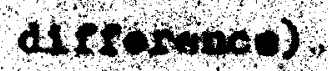

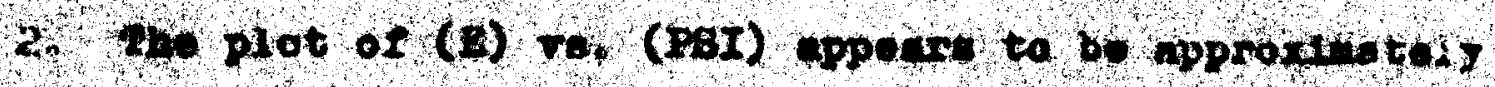

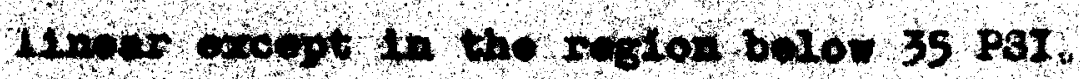

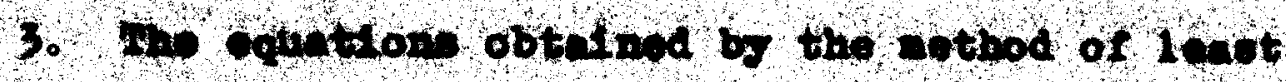
reveros dor

$$
\begin{aligned}
& 5-2431+9.79 x \quad \text { or E - 1431+979 (PBI) } \\
& J+(5.17 \times 10-3)-\left(7.41 \times 10^{-6}\right) \times \text { or } 0 \cdot(5.27 \times 10-3) \cdot\left(7.41 \times 10^{-6}\right) \times 11
\end{aligned}
$$

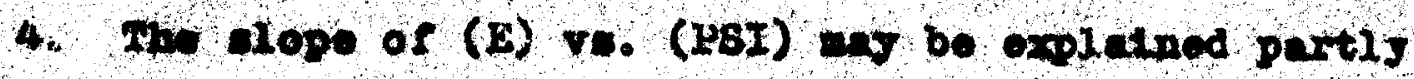

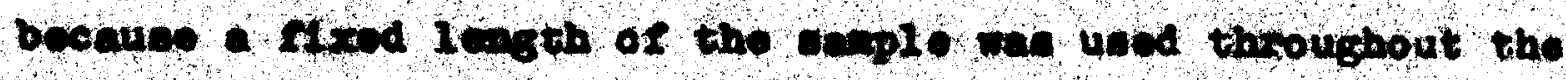

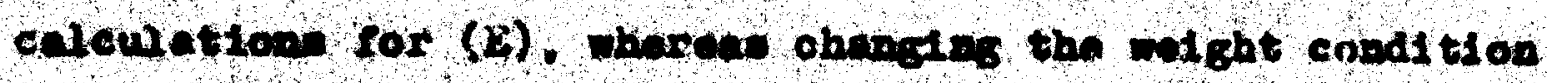

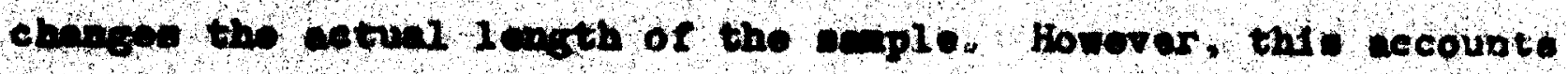

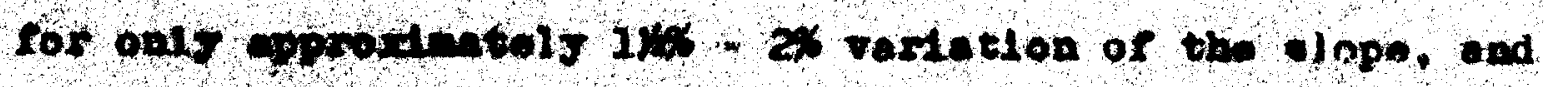

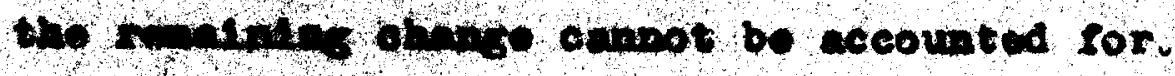

5 Wh blope of (G) vo. (PSI) Is 00 enall that it og bo contidond to bo wero. 


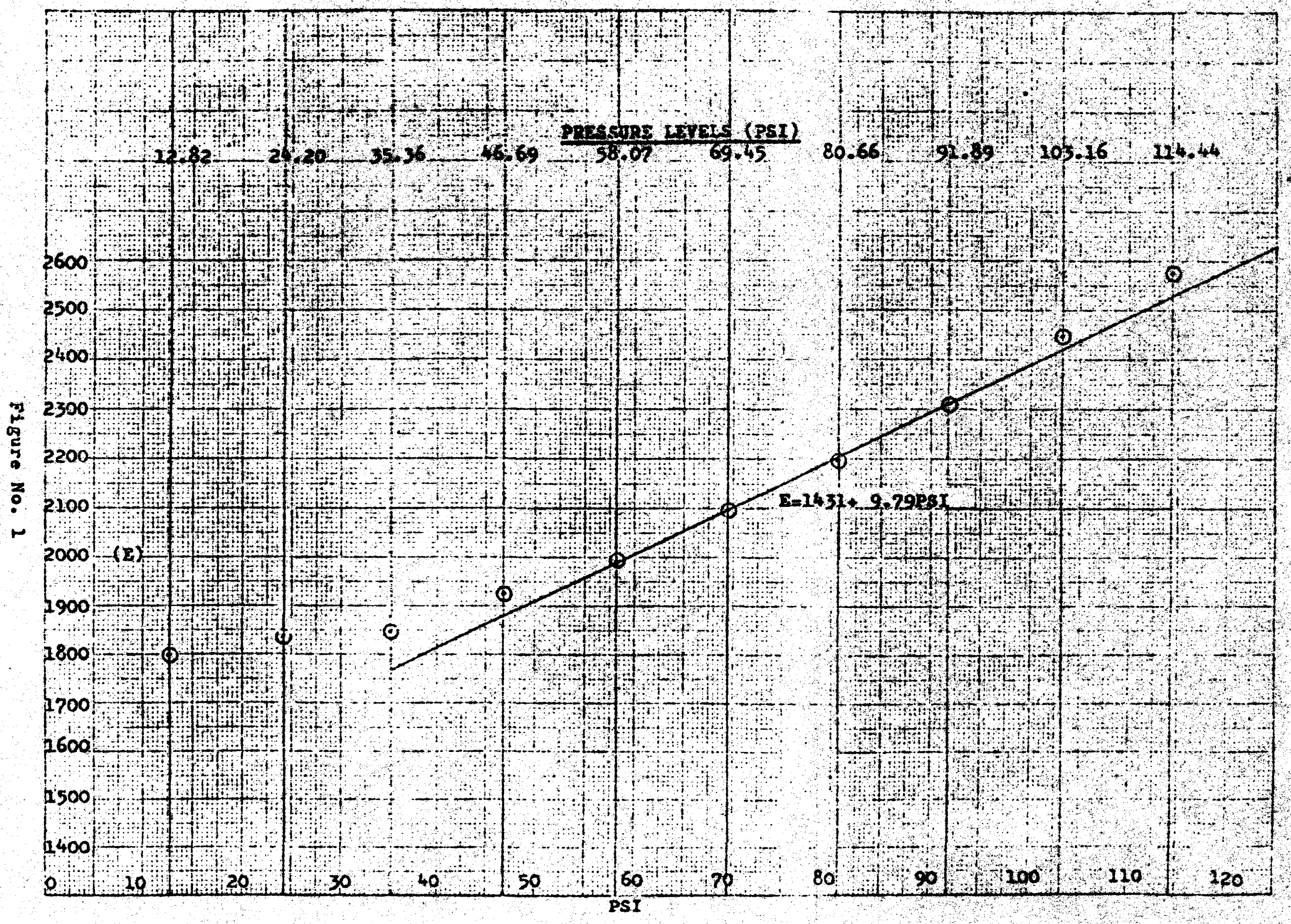




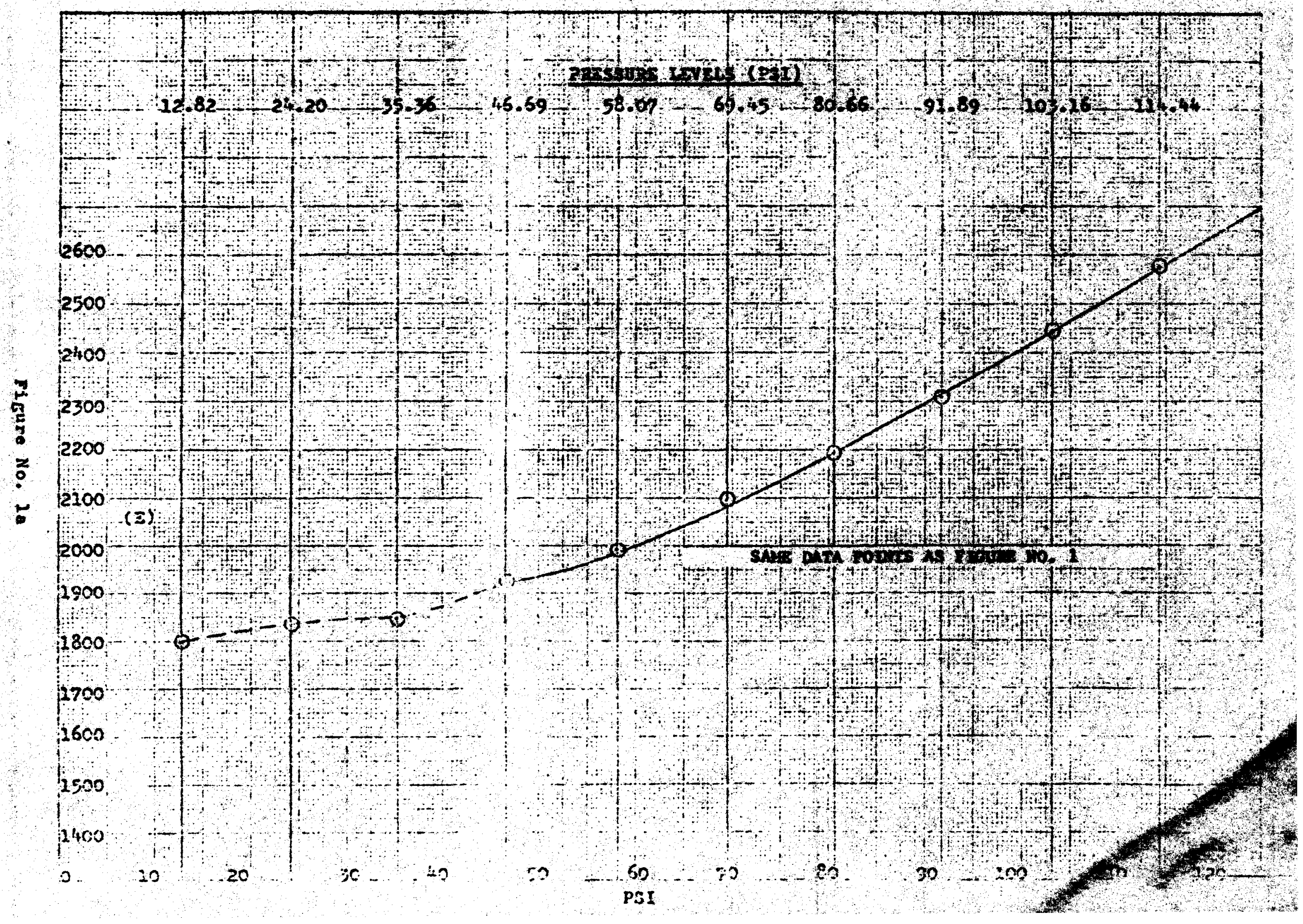




\section{Gavg. VS. PSI}

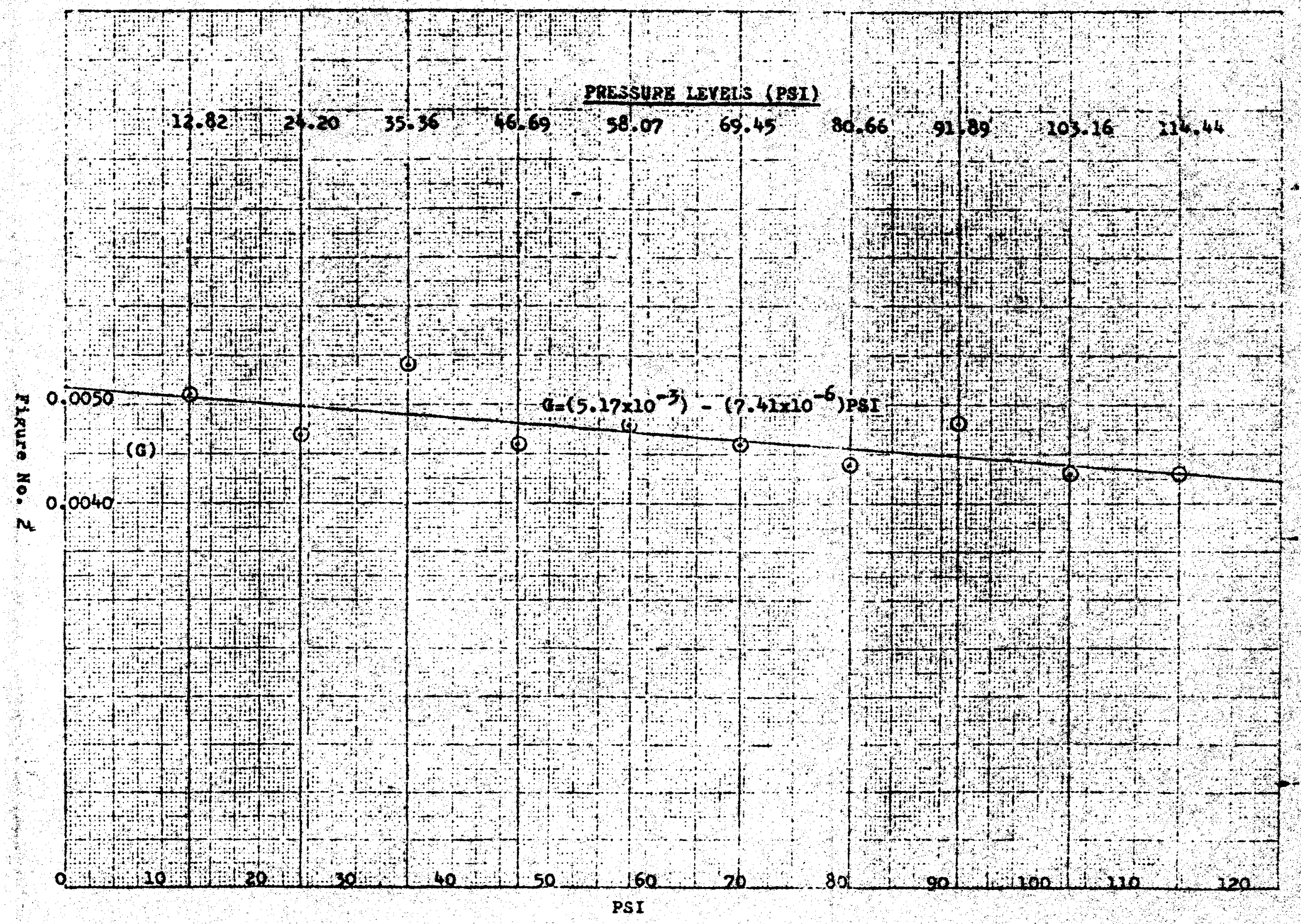




\begin{tabular}{|c|c|c|c|c|c|c|c|}
\hline \multirow{2}{*}{\multicolumn{2}{|c|}{ Spoedmen Mo, }} & \multicolumn{6}{|c|}{$E(P S I)$} \\
\hline & & \multirow{2}{*}{$\frac{\begin{array}{l}2002- \\
38-1\end{array}}{2612}$} & \multirow{2}{*}{\begin{tabular}{|l|}
$2002-$ \\
$38-2$
\end{tabular}} & \multirow{2}{*}{$\frac{\begin{array}{l}2008- \\
38 m 3\end{array}}{1906}$} & \multirow{2}{*}{\begin{tabular}{|l}
$2202-$ \\
$39-1$
\end{tabular}} & \multirow{2}{*}{\begin{tabular}{|l|}
$232-$ \\
$39-2$ \\
1831
\end{tabular}} & \multirow{2}{*}{\begin{tabular}{|l|}
$\begin{array}{l}2102- \\
39-3\end{array}$ \\
1758 \\
\end{tabular}} \\
\hline \multirow{10}{*}{$\begin{array}{l}\text { Geroert } \\
\text { CondrIons }\end{array}$} & 2 & & & & & & \\
\hline & 2 & 1689 & 2722 & 2926 & 2049 & 1853 & 1782 \\
\hline & 3 & 1729 & 1752 & 1936 & 2031 & 1842 & 2796 \\
\hline & 4 & 1806 & 1836 & 1992 & 2138 & 1889 & 1896 \\
\hline & 5 & 1931 & 1876 & 2065 & 2186 & 1967 & 1930 \\
\hline & 6 & 2062 & 1968 & 2182 & 2280 & 2069 & 2026 \\
\hline & 7 & 2199 & 2059 & 2259 & 2364 & 2171 & $212 ?$ \\
\hline & 8 & 2292 & 2182 & 2359 & 2517 & 2304 & 2208 \\
\hline & 9 & 2481 & 2315 & 2510 & 2634 & 2404 & 2344 \\
\hline & 10 & 2601 & 2471 & 2586 & 2717 & 2568 & 2502 \\
\hline \multicolumn{2}{|l|}{ AVERAGE } & 2040 & 1985 & 2172 & 2293 & $20 \times 10$ & 2035 \\
\hline
\end{tabular}

TABLE NO 1

"Re-Examined"(E) 


\begin{tabular}{|c|c|c|c|c|c|c|c|}
\hline & & & & 8 & & & 8 \\
\hline spuctura & & $\begin{array}{l}2002 \\
30-1\end{array}$ & $\begin{array}{l}2002- \\
38-2\end{array}$ & 3002 & $\begin{array}{l}2002 \\
39-1\end{array}$ & $\begin{array}{l}2002- \\
39,2\end{array}$ & $\begin{array}{l}2002- \\
39-3\end{array}$ \\
\hline & 1 & 2599 & 1669 & 2878 & 2016 & 1859 & 2758 \\
\hline & 2 & 1689 & 2703 & 1907 & 2029 & 1834 & 1781 \\
\hline & 3 & 2729 & 1752 & 1936 & 2007 & 1866 & 1773 \\
\hline & 4 & 1802 & 2810 & 2029 & 2138 & 193.6 & 1859 \\
\hline & 5 & 2932 & 1876 & 2097 & 2186 & 1967 & 2930 \\
\hline Condrions & 6 & 2062 & 1935 & 2182 & 2280 & 2069 & 1993 \\
\hline & 7 & 2161 & 2059 & 2257 & 2325 & $21 \times 4$ & 2085 \\
\hline & 8 & 2292 & 2241 & 2359 & 2473 & 2304 & 2209 \\
\hline & 9 & 2435 & 2315 & 2420 & 2634 & 2404 & 2389 \\
\hline & 10 & 2552 & 2519 & 2537 & 2707 & 2519 & 2502 \\
\hline IVERACE & & 2026 & 1978 & 2160 & 2280 & 2087 & 2028 \\
\hline
\end{tabular}

TaBjo HO, 2

"Ortguaj" (E) 